STATE OF ILLINOIS

DEPARTMENT OF REGISTRATION AND EDUCATION

DIVISION OF THE

NATURAL HISTORY SURVEY

STEPHEN A. FORBES, Chief

Vol. XIV.

\title{
FIRST REPORT ON A FORESTRY SURVEY OF ILLINOIS
}

BY

ROBERT B. MILLER

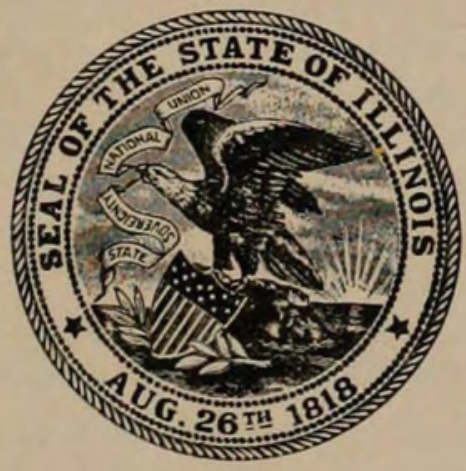

PRINTED_BY AUTHORITY OF THE STATE OF ILLINOIS

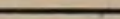

URBANA, ILLINOIS

March, 1923 


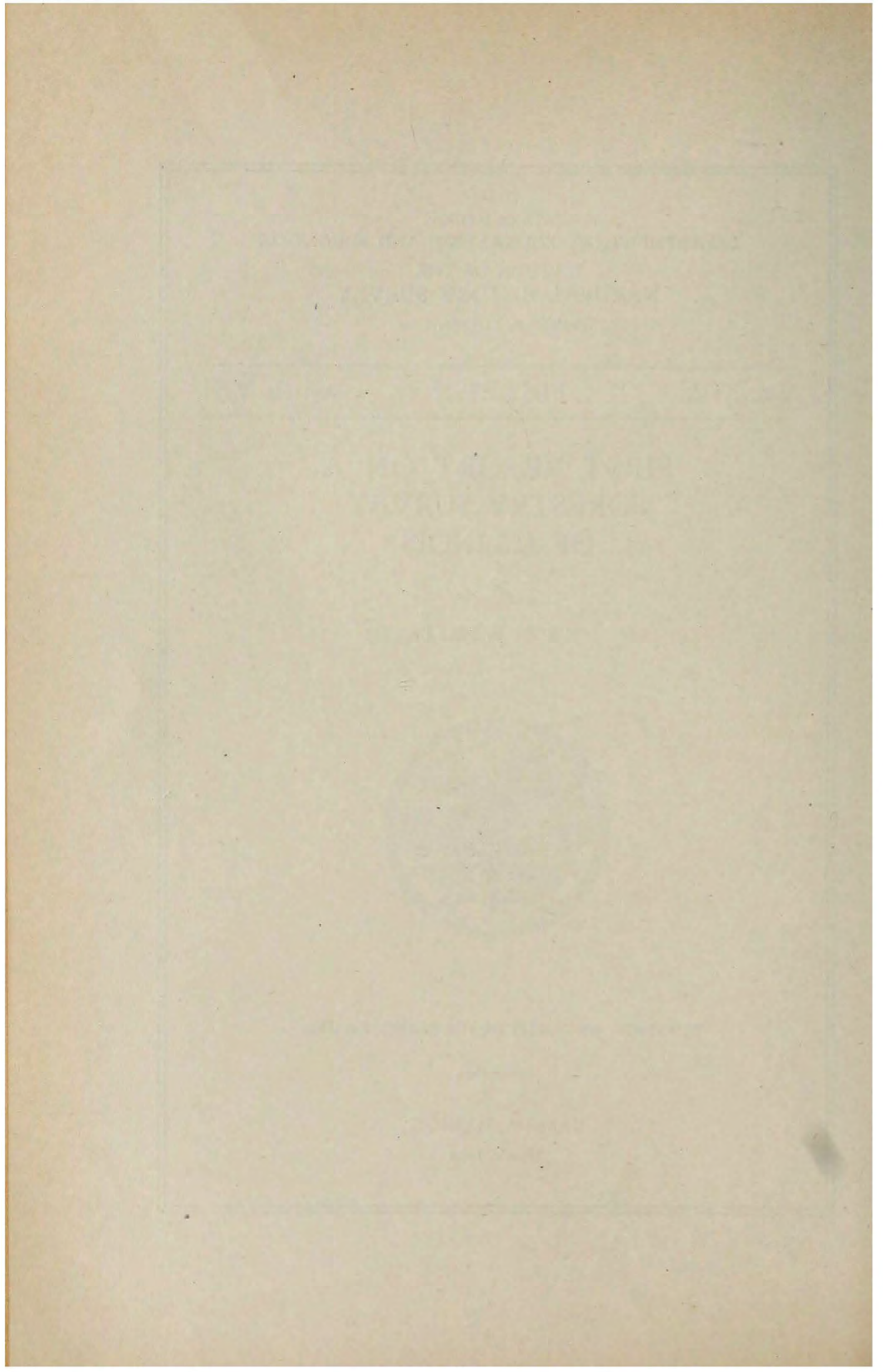


STATE OF ILLINOIS

DEPARTMENT OF REGISTRATION AND EDUCATION

A. M. Shelton, Director

BOARD OF

NATURAL RESOURCES AND CONSERVATION

A. M. Shelton, Chairman

WILLIAM TRELEASE, Biolog $y$ JoHN M. Coulter, Forestry Edson S. Bastin, Geology

William A. Noyes, Chemistry
JOHN W. ALVORD, Engineering

KENDRIC C. BABCOCK, Representing the President of the University of Illinois

THE NATURAL HISTORY SURVEY DIVISION

Stephen A. Forbes, Chief 



\section{CONTENTS}

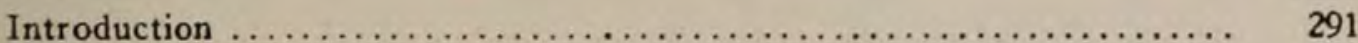

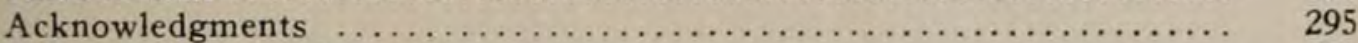

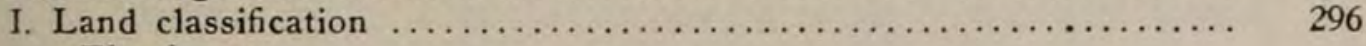

The forest:

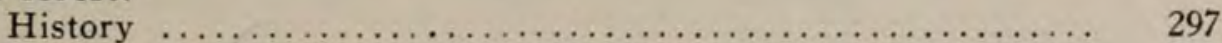

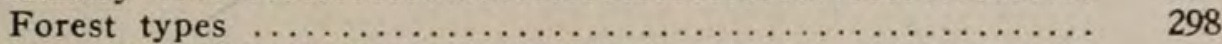

Detailed exhibit of stand of types by counties for area surveyed,

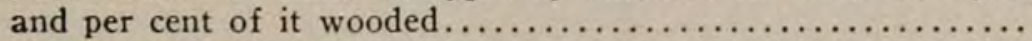

Important trees and their main uses:

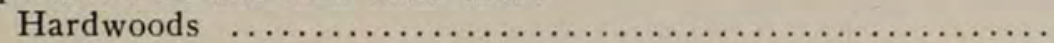

Tabulated data obtained by a study of types of upland and bottomland timber $\ldots \ldots \ldots \ldots \ldots \ldots \ldots \ldots \ldots \ldots \ldots \ldots \ldots \ldots \ldots \ldots \ldots \ldots \ldots \ldots, 313-317$

Annual cut in board feet ............................... 317

Physiographic features:

Topography $\ldots \ldots \ldots \ldots \ldots \ldots \ldots \ldots \ldots \ldots \ldots \ldots \ldots \ldots \ldots \ldots \ldots \ldots \ldots \ldots \ldots \ldots, \quad 318$

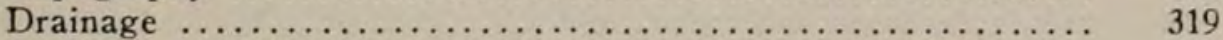

Geology ................................... 320

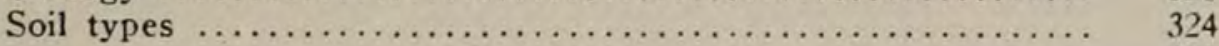

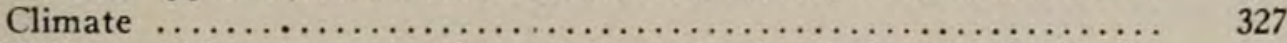

II. Milling and logging operations and wood-using industries in South-

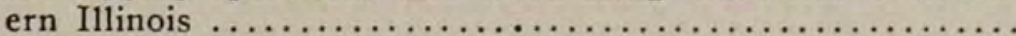

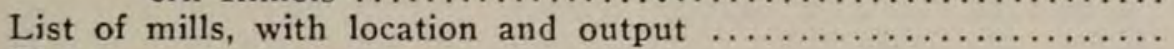

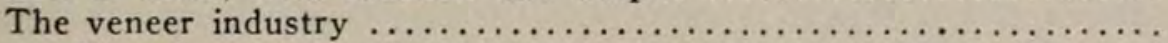

Manufacturers in the region, and products .................

Necessity for a local supply of "softwoods" for veneer purposes

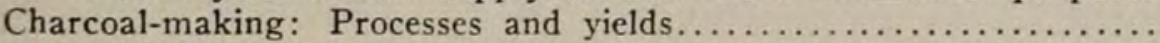

Ties and mine timbers:

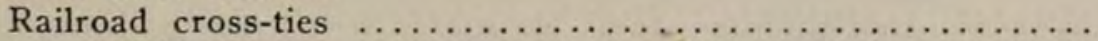

Specifications, grades and sizes, species ...............

Wood preservation and tie-treating plants in Illinois ......

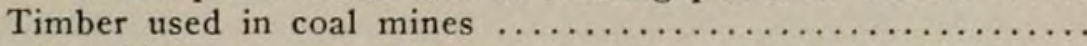

III. Forest problems:

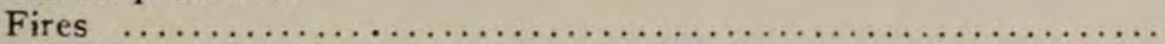

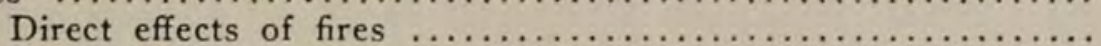

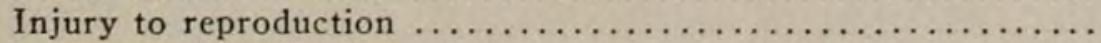

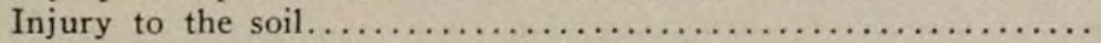

Injury to productive power of the forest $\ldots \ldots \ldots \ldots \ldots \ldots \ldots$.

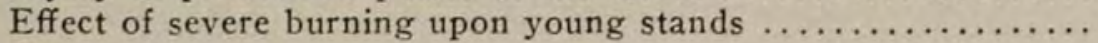

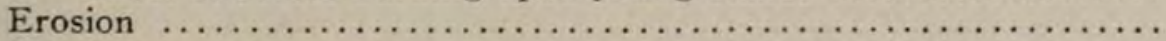

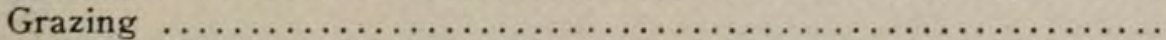

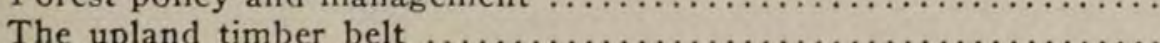

Outline of proposed fire-protection system for upland timber

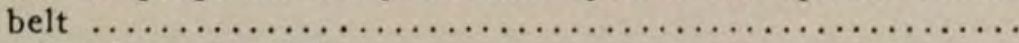

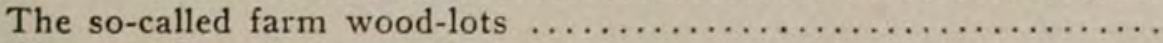

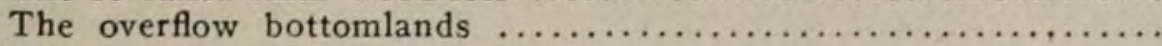

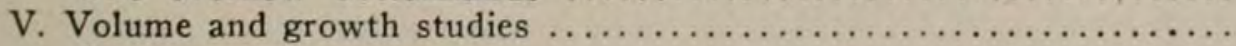

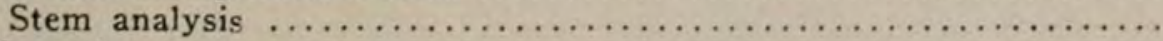

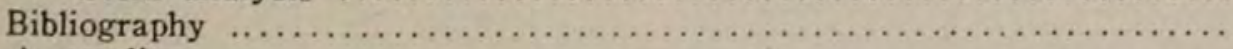

Volume tables for leading species, and taper and growth tables and

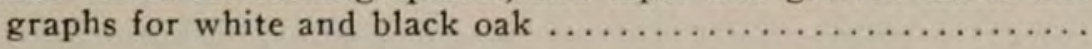




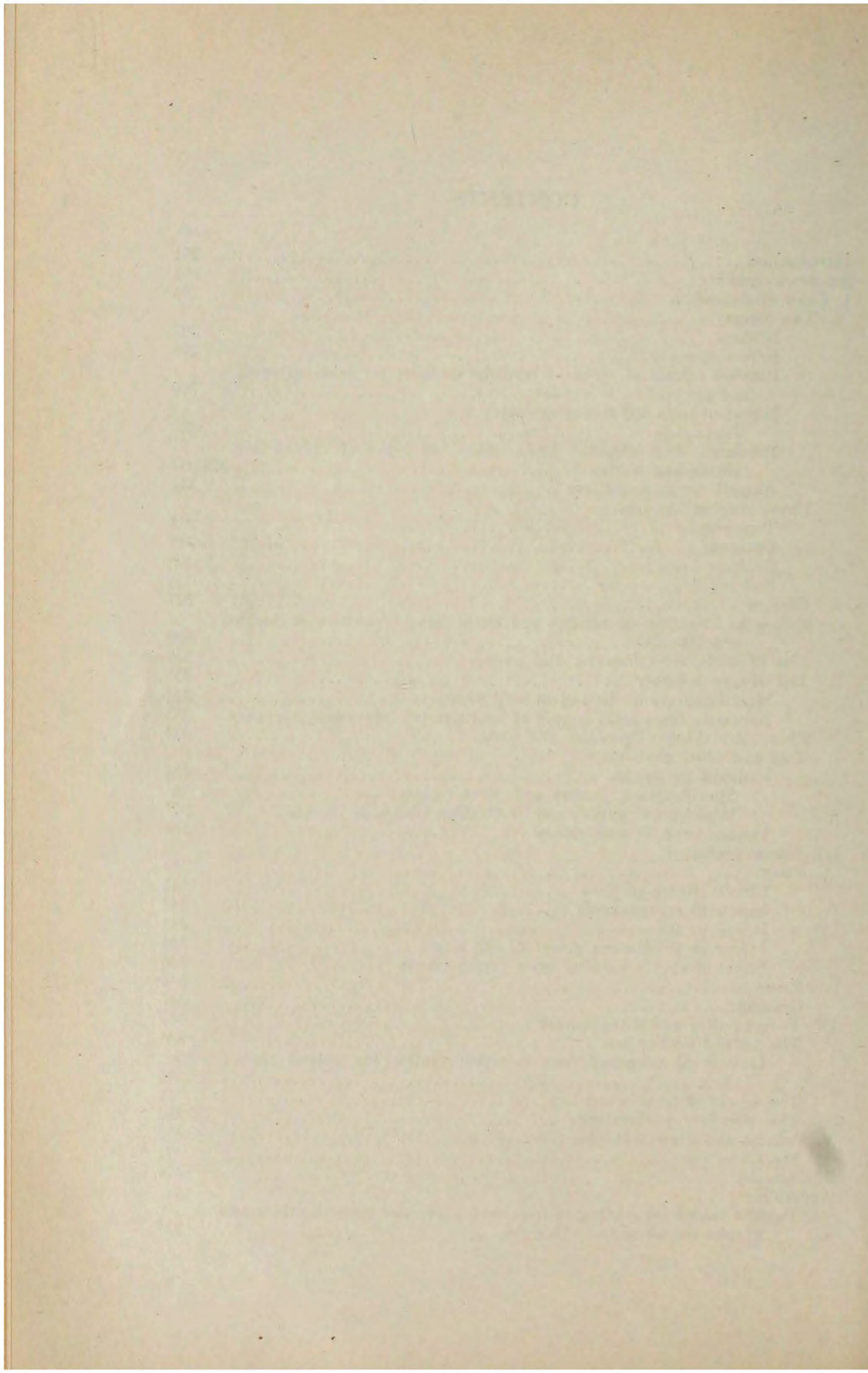


ARTICLE VIII.-First Report on a Forestry Survey of Illinois. By Robert B. Miller, Forester, Natural History Survey.

\section{INTRODUCTION}

The forest area in Illinois to which this report applies is bounded by the Mississippi River on the west and the third principal meridian on the east, and extends in a north and south direction from Thebes, in Alexander county, to Chester, in Randolph county. It comprises all of Jackson county and portions of Union, Alexander, Pulaski, and Randolph counties, a total of 697,286 acres. It forms the western part of the Ozark highlands of southern Illinois (Colyer, '22), a region which extends across the state for 75 miles, with an average width of about 25 miles, from the mouth of the Big Muddy on the Mississippi to Shawneetown on the Ohio. The highest elevation of this highland belt is "Williams Mountain" (1,065 feet), in the northeastern part of Pope county, Bald Knob, in Union county, coming next, with an elevation of 1,025 feet. The difference of elevation between the crest and the base of the Ozarks is often 500 to 600 feet. A relief map of the state shows that this entire highland region includes the southern parts of Jackson, Williamson, Saline, and Gallatin counties, almost the whole of Union, Johnson, Pope, Hardin, and Alexander counties, and a part of Massac county. Reports of the State Soil Survey for these ten counties show that the amount of rough and hilly land ranges from 23 per cent in Gallatin county to 79 per cent in Hardin county. From the topography of these uplands and the lightness of their soils, which are classed either as yellow-gray or light gray silt-loams, it can be seen that the forces of erosion must be at their maximum, so that most of the region is in a mature stage of dissection.

The occupations of the inhabitants are directly related to the topography of the region. The bottoms of the Mississippi, Big Muddy, and Cache rivers make very fertile farming lands, suitable for corn when drained and cleared, while the steeper cleared lands may be used for mixed farming, but are better adapted to wheat than to corn. The narrower bottoms of secondary streams are adapted to the raising of berries, melons, cucumbers, and tomatoes, for the marketing of which there are good transportation facilities. Extensive peach and apple orchards have been developed in some portions of the upland because the higher parts often escape frosts which are destructive on the lower levels. Some of the 
uplands, besides having a value for timber growing and stock raising, are underlaid with coal or contain deposits of silicon, ganister, and kaolin. Cliffs of limestone are frequent and furnish fertilizer and building stone, and the chert ledges yield road material.

The western portion of this highland region was chosen as a subject for a preliminary report on forest conditions for the following reasons:

1. It has the most continuous body of timber in the state, and because of its nearness to important wood-using centers is admirably located for continuous forest management.

2. The timber, being largely on uplands, is on cheap land which is poorly adapted to agriculture under ordinary methods of cropping because of high elevation, steep slopes, and a soil which erodes very badly when the protecting forest cover is removed.

3. A very considerable amount of information concerning the region has been accessible to us. The soil map and report on Union county are now in course of preparation by the State Soil Survey, while topographic maps of the Alto Pass, Jonesboro, Carbondale, and Dongola quadrangles are in various stages of preparation by the State Geological Survey, detailed information having been available both on the geology and soils of the region.

4. When the time comes for Illinois to acquire land for state forests, it is believed that this report and the accompanying map will be of service in showing where suitable tracts are located and will give some idea of their nature and value. As Henry S. Graves ('21) points out, the acquisition of public forests by states would furnish examples of the best methods of protecting and handling forests in the regions in which they were established. Thus managed they would also help to strengthen the local wood-using industries by assuring a regular supply of timber and would become real factors in the upbuilding of rural communities.

The total area represented by the map of this region accompanying this report, is 697,286 acres, 522,250 of which are cleared or in pasture and 175,036 acres are woodland. There are 147,636 acres of timber which may be classed as merchantable, 131,217 acres being upland and 16,419 acres bottomland timber. There are 13,299 acres which may be classed as culled forest, which means that the merchantable trees have been removed as the demand came, leaving trees which were defective, of inferior species, or too small for the market. Such lands have a future value if fire is kept out of them for a few years until the slash decays and reproduction has started. There are 14,100 acres classed as saplings, that is, the ground is well covered with trees of sapling and pole sizes, not yet merchantable, but which will have a distinct value within the next ten years if properly protected and handled. Of the entire area covered 
by our map, 30.8 per cent is wooded, and that portion west of the Mobile and Ohio Railroad (which forms a rather distinct boundary between the more solid timber and the region of scattered wood-lots to the east) is 45.9 per cent wooded. This region west of the railway is also different in its problems from the region of scattered wood-lots to the east, where the tracts surrounded by roads can be better protected by their owners against fire.

In the 131,217 acres of upland forest, the main species and the per cent of the stand which they form, are as follows: black oak, 27.6 per cent; white oak, 20.8 per cent; beech, 18.1 per cent; hickory, 14.1 per cent; and tulip-tree, 5.1 per cent. Miscellaneous species, such as maple, black gum, red gum, ash, elm, walnut, and mulberry make up the remainder of the stand. Stand tables compiled for 117 acres at Alto Pass and for 65 acres at Jonesboro, both areas of the upland type, show that on the former area there were standing on an average acre only 33.32 trees of all species 6 inches or more in diameter breast-high; and on the latter area, only 43.65 trees of all species of this size per acre. The average acre at Jonesboro contained 1,948 board feet and at Alto Pass 2,362 board feet, while a combination of the figures for 182.3 acres gave 2,228 board feet, or 8.68 cords per acre, counting 90 cubic feet as equivalent to one cord. These figures of the number of trees per acre, when compared with those for very similar sites which we find in published yield-tables, show that these forests are decidedly understocked, because of fires and culling. The culling out of the larger specimens has its justification in meeting the demands of the market for certain species as they become valuable, and does not impair the usefulness of a forest as a protection against erosion; but the prevalence of fires is entirely unjustifiable on any grounds, and owners should be given assistance and encouragement in controlling them along the lines discussed under "Policy and Management."

Our map shows 16,419 acres of bottomland forests; but not much time was spent on the bottoms because only that portion of them needs to be considered which is incapable of drainage or which has an impervious subsoil. We listed 2,894 acres of $1 \mathrm{~B}^{*}$ cypress on these lands and some No. 4* cypress running as high as 13,000 board feet per acre; but cypress is mostly in small patches or mixed with bottomland hardwoods. Owing to the number of drainage ditches, cypress will not long rank as a commercial species, since when cut on drained land its place is taken by gums, willow, soft maple, and cottonwood, called locally "softwoods." This latter variety of forest, when situated on land which can not be deroted to agriculture for some years because of periodical floods, should

*See pages 298, 299. 
not for that reason be overlooked, since it is valuable for the manufacture of veneers, and of charcoal for gunpowder, and willow and cottonwood are used for soda pulp manufacture. Where another crop of this timber can be raised on the land before it is needed for farming, it should certainly be utilized for timber-growing, since it is less subject than the upland to damage by fires, and makes more rapid growth.

From the most reliable information obtainable, we estimate the annual cut of timber in the region covered by our map at about $20,000,000$ board feet. The veneer industry uses a large amount of the local supply for veneers for baskets and crates and hampers for fruit and vegetables; the railway companies secure large numbers of railroad ties from species along their rights-of-way which may be used directly or are sent for treatment to the wood-preserving plants in that region; stationary and portable mills saw out lumber, cross-ties, car stock, and mine ties; while a very large amount of round timber purchased by contractors is shipped to mines in the counties farther east in the form of props, legs, and cross bars as well as hewed motor and mine ties. The present supply is coming from woods which if not practically destroyed in many cases by cutting and fires, are at best left with too few or too small trees to replace, by their annual growth, the volume removed by cutting. Even though some of these forests are of poor quality, they represent a resource which if properly developed will contribute very largely to the prosperity of the individual owner and of the community. Development lies along the line of their protection from fire and a handling which will improve their composition and the quantity and quality of their product. Maintenance of a supply of local timber such that the mills of the region will not be forced to move to other sources of supply, as to Arkansas and Missouri, and a development of new industries which will make a market for such species as cottonwood and willow, are measures of a constructive forestry policy. While stressing better protection and the handling of existing stands, we do not intend to underestimate in any degree the importance of a restoration of deforested and waste lands to productiveness by planting them when such a measure is necessary.

The main problem in this region is the prevention of forest fires. Our investigations show that fires are the chief cause in reducing the number of trees far below what should stand on an average acre of upland forest, and are therefore chiefly responsible for the reduction in the volume per acre and in the amount of wood which accrues each year by growth. Some sample plots show that at least 70 per cent of the reproduction and young growth is killed by fire. This thinning out of the stand places the trees too far apart for adequate natural pruning and admits so much light that grass and weeds come in, hindering the reproduction of the better species of trees and further increasing the fire danger. 
A comparison of the present area of the upland forest at Alto Pass with soil and topographic maps of the same area shows that a large per cent of the forest is on the yellow silt loam along streams, where woods are needed to protect the banks and prevent erosion, and that clearing has about reached the limit of safety for the ultimate good of such lands. The increase, year after year, in some of the southern counties, of lands once farmed and now abandoned, shows that areas hewed out on the slope or the top of a ridge are not adapted to permanent agriculture, while grazing them will undoubtedly result in erosion and the formation of gullies. More intensive cultivation of land already cleared is a better agricultural policy than the further clearing of woodland areas of this description.

The Mobile and Ohio Railroad runs from Sparta to Cairo through this region and divides it into two parts-a western, embracing most of the upland timber which is in more or less solid blocks; and an eastern, which is also rough and hilly but contains timber in wood-lots interspersed with farms and orchards. The Missouri Pacific Railway, from Chester to Cairo, traverses the bottomland on its western edge. It is paralleled from Gorham south by a branch of the Illinois Central, while the main line of the Illinois Central from Chicago to Cairo cuts through its eastern side. One of the main auto roads running north and south, the "Egyptian Trail," is being built through it, while other roads, hilly but quite passable, connect Anna and Jonesboro with Cape Girardeau, Mo., and other points on the Mississippi. The roads in the back country shown on the U. S. topographic sheets as dotted lines can be easily traversed in summer with a light car or a buggy, since they usually wind up some rocky stream bed, or along the tops of the ridges. Where they cross wooded country the best mode of travel is on horseback or on foot, since in this way one can secure from high points the best idea of the country.

\section{ACKNOWLEDGMENTS}

We are particularly indebted to Dr. R. S. Smith, of the State Soil Survey, for base maps of many of the counties, without which rapid covering of this territory would have been impossible; also to the chief and members of the soil survey party working on the Union county soil report, for information about the soil types in advance of publication of the report. Our sincere thanks are also due the Director of the United States Geological Survey for woodland sheets of the Dongola and Alto Pass quadrangles and for the Carbondale topographic sheet, and to Mr. J. A. Duck, chief of the topographic survey party in that region, for valuable assistance. The woodland sheets published by the State Geological Survey have been freely used, and have been of very great assistance as accurate base maps and for timber location; and Professor T. E. Savage and Mr. Frank Krey, of the Survey staff, have generously furnished us 
with information on the geology of the region as a whole, and on specific areas-such as the Jonesboro and Dongola quadrangles.

\section{Land Classification}

Land is classified by the county assessors as improved or unimproved, the latter including woods and pastures. A brief statement of condi tions for the three main counties embraced in this report is as follows:

\section{County \\ Alexander Jackson \\ Union}

\begin{abstract}
Improved land
63,806 acres

224,703 acres

159,901 acres
\end{abstract}

\section{Unimproved land \\ 73,163 acres \\ 155,894 acres \\ 98,019 acres}

The average assessed value of land (which is half the market value) varies from $\$ 2.04$ to $\$ 4.23$ per acre for the unimproved and from $\$ 9.24$ to $\$ 28.88$ for the improved lands. These figures are given to show that there is a decidedly large acreage of unimproved land in these three counties-about 327,000 acres - and that its valuation, even at $\$ 4.23$ per acre, is not so high as to discourage its purchase by public or private owners interested in the practice of forestry. In some of these southern counties where bottomland is assessed at $\$ 100$ per acre its use for forestry purposes is of course out of the question.

For our purpose, we may classify the land under three heads: (1) cleared farm lands, (2) woodlands, and (3) absolute forest lands. By cleared land we mean that which was once cleared, even if it is now growing up to bushes. If reproduction on this is satisfactory, it is classed under saplings. By absolute forest land is meant, as ordinarily defined, "land fit only for forest growth." Since this would greatly restrict the area for forestry in this area, we prefer to say that absolute forest land is that which, on account of excessive slope, rockiness, poor drainage, or other features, will grow a forest crop more profitably than any other. Under it would come gullied land whose reclamation by farming methods would be excessively costly, bottomland which can not be successfully drained, and bare rock cliffs. The area of the last is insignificant.

The distinction between farm and absolute forest land is outside the present discussion, requiring an economic survey of some limited area typical of conditions in a much larger one, in which all the factors of cost of different crops, markets, and transportation conditions, should be considered by a forester who has specialized in economics; and such a survey is contemplated by the Natural History Survey as a part of its forestry program. The most reliable data to be obtained by soil specialists, agronomists, and foresters should form the basis of such an investigation and the results should go far to settle the best uses of our untilled lands.

For our present purposes, land classification and utilization may be covered by the questions: (1) Is the land being profitably farmed now? 
(2) Is it reasonably certain that it will be profitably farmed during the time required to grow a commercial forest on that site? If that presumption is not reasonable, then that area belongs in forest and should stay in forest.*

This would temporarily dispose of any questions as to our gullied lands or wet undrained bottomlands.

Of the entire area mapped, $30.8 \%$ is wooded; of that east of the Mobile and Ohio Railroad $16.1 \%$ is wooded; while west of the same tracks the woodland area rises to $45.9 \%$. The western upland region, with its high per cent of wooded area in rather large tracts, surrounded by passable roads, thus forms a distinct unit in any plan of management or protection, being the most important as a source of revenue and as a protection forest. The Mississippi bottoms are destined to be brought under cultivation in time; and much of this land is, in fact, already included in organized drainage projects and is being profitably farmed. This 129,846 acres of bottomland can therefore be disregarded excepting those parts of it which can not be drained, and these we have not attempted to distinguish. The classification of upland and bottomland timber types, with their acreages, will be found under the head of "Forest Types," pp. 298 and 299.

\section{The Forest HISTORY}

Originally the entire area was covered by a dense forest. On the uplands white and black oaks predominated, mixed with such other species as hickory, beech, black gum, red gum, hard maple, tulip-tree (commonly called yellow poplar) and cucumber-tree, these original forests averaging well over 8,000 board feet per acre. White oak and tuliptree were early marketed, the former probably for staves and heading, and the latter for exterior finish or framing material for barns and houses. The best of hickory was cut for wagon material, and this practice of culling out the best species according to the demands of the market has continued to the present time. About 1870 , commercial orcharding developed in this general locality because some of the knobs and slopes were found to be usually very free from injury by frost. This made a demand for barrels and baskets, so that a market was afforded for many "softwoods" (commercial usage) which has continued down to the present, when many of the cheaper species can also be used for veneers. Beech, which at one time was practically unused, was then sought in the ravines and coves because it was found that, when given a preservative treatment, it made a good durable railroad tie. Sycamore, hackberry, and soft maple could also be so used.

*Lovejoy, 19. 
Repeated cullings have thus reduced the number of older trees standing upon an acre and repeated fires have prevented young trees from filling up the blanks. As a result, the present stands show an average of only 33 to 43.5 trees per acre, although normal yield-tables for such hardwoods made up from fully stocked stands show that at least 130 trees per acre, or four times as many, should be present (see stand tables for sample acres at Alto Pass and Jonesboro, pp. 313, 314). This decrease of growing stock means diminished volumes in such stands and reduced growth per acre.

The depletion of the stands has been stimulated by the excellent marketing and shipping facilities. Four lines of railway traverse this region in a north and south direction - the main line of the Illinois Central from Chicago to Cairo on the eastern side, the Mobile and Ohio through the center of the area, and on the west a branch of the Illinois Central and one of the Missouri Pacific running parallel from Leo Rock to Thebes. The nearness of these railroad lines makes it possible to ship logs, mine props, and railroad ties without hauling them any great distance. Several veneer plants are located on the main line of the Illinois Central and various wood-using industries have been built up at Cairo and Mound City, which, while drawing the bulk of their logs from the Ohio and Mississippi rivers, yet use some local logs.

\section{FOREST TYPES}

We have divided the forests of this region into upland and bottomland types, but no attempt has been made at further division on a basis of site. While we may use the terms beech-maple, oak-hickory, and the like, in distinguishing forests in this region we shall attempt no close definition of their limits as it would be almost an impossibility to trace them. Writing of the forests of Alexander county, Ill., Dr. George D. Fuller ('22) very pertinently says: "The various types and their subdivisions merge into one another by gradations that are often almost imperceptible, presenting degrees of difference that are quite impossible to discuss or map in a preliminary survey like the present study."

Of the upland types we have distinguished the following:

Culled forest-text symbol, Cull*.-Stands from which merchantable trees have been entirely removed, with occasional weed, or defective, trees left. There are 12,584 acres of this type.

Saplings - text symbol, Sap.-Stands in which the trees are not large enough to be merchantable, including growth coming in on old fields or after a previous cutting. This type has a distinct future value. There are 13,489 acres of this type.

*The symbols given in this connection are used only in the text and tables, our map of the region being self-explanatory. 
No. 1-text symbol, 1.-Stands from which the more desirable species and best trees have been cut. There are 118,247 acres of this kind of timber mapped, with an average of 1,000 and a maximum of 2,000 board feet per acre.

No. 2-text symbol, 2.-Stands yielding from 2,000 to 5,000 board feet per acre, with an average of 3,750 board feet. These are generally very fair stands of desirable species where light cullings have been made. Our map shows 12,584 acres in this division.

No. 3-text symbol, 3.-Stands which will run from 5,000 to 10,000 board feet per acre; probably typical of the original stands, with an average of 7,500 board feet. No culling, or at most very light culling has taken place. The area is only 368 acres.

No. 4-text symbol, 4.-Stands which are exceptionally good, where the trees are large and are generally on good agricultural soil, with a yield of over 10,000 board feet per acre. Only 18 acres were classed as of this type.

Total of the upland types, 157,290 acres.

For the bottomland types the same designations as to yield are used as are applied to uplands except that each is followed by the letter B.

Culled forest-text symbol, Cull B...... 715 acres

Saplings-text symbol, Sap. B........ 612 acres

No. 1 -text symbol, $1 \mathrm{~B} \ldots \ldots \ldots \ldots \ldots 12,473$ acres

No. 2-text symbol, 2B............ 937 acres

The foregoing are the straight bottomland symbols, but when strictly bottomland type and hardwoods are mixed with cypress we have the following:

$$
\begin{aligned}
& \text { 1B cypress } \ldots \ldots \ldots \ldots \ldots \ldots .2,894 \text { acres } \\
& 2 \mathrm{~B} \text { cypress } \ldots \ldots \ldots \ldots \ldots \ldots \ldots, 115 \text { acres }
\end{aligned}
$$

Total of the bottomlands types, 17,746 acres.

The strictly bottomland type as distinguished from the upland type is characterized by a greater number of species. These are pin, white, swamp white, red, and bur oaks, elm, sweet gum, hickory, locust, black walnut, and tulip-tree. Where cypress is found there is usually tupelo, red gum, and soft maple, with some willow and cottonwood.

The composition of the upland type is well shown by the two standtables on pages 33 and 34, compiled from strip surveys representing 117.18 acres at Alto Pass, and 65.14 near Jonesboro. The cruising was done by a three-man party, one man running the line with a staff compass and tallying, and two others, known as caliper men or cruisers, each taking a strip 33 feet in width on one side of the chain, calling out the species, 
diameter breast-high, and merchantable heights of all trees 6 inches in diameter and over on his side of the chain. Topographic maps giving the location of ravines and ridges are very useful in cruising by this method, and in very rough country the steel tape may be dispensed with. When the party has progressed ten chains (660 feet) in this manner and with this width of strip ( 66 feet) they have covered one acre.

The area cruised out of a section of 640 acres will of course depend on the distance between the cruise lines. When they are run at intervals of 20 chains (a quarter of a mile) they give a 5 per cent estimate, and when at intervals of 10 chains (an eighth of a mile, or 660 feet), a 10 per cent estimate. In addition to recording the apparent effect of fires upon young growth, plots a square rod in size were measured off at intervals of 10 chains in order to estimate reproduction. This plotting is easily and quickly done by the use of a 50 -foot cloth tape, taking $161 / 2$ feet on the center cruise-line and having the men form a square with the cloth tape $16 \mathrm{r} / 2$ feet on the other three sides. All sprouts and seedlings within the square are then counted and tallied, with a designation as to height. This represents reproduction on $1 / 160$ of an acre.

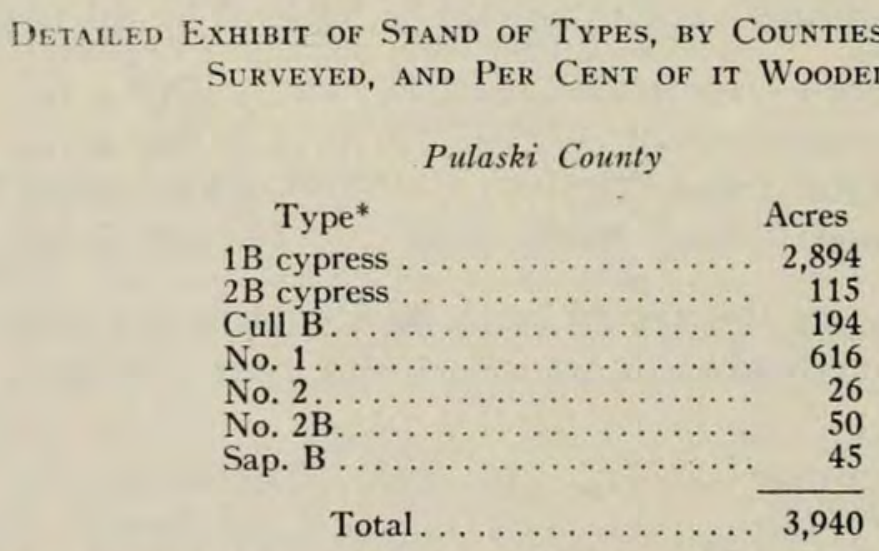

Total area of county surveyed was 35,000 acres, $11.2 \%$ of it wooded.

\section{Randolph County}

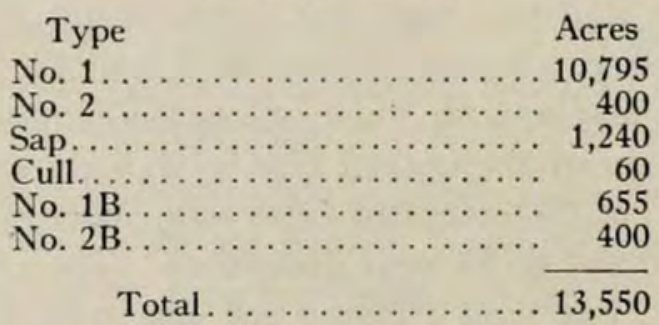

Total area of county surveyed was 26,427 acres, $51.2 \%$ of it wooded.

*For definitioñof type symbols see pp. 298, 299. 
Timber west of

\section{Union County}

M. \& O. R. R. to Timber east of Total area of Mississippi M. \& O. R. R. timber in types

\section{Type}

\section{Bluffs}

No. 1

No. 2 ........

Acres

23,564

6,762

Cull..........

Sap...........

No. $3 \ldots \ldots \ldots$.

No. $4 \ldots \ldots \ldots$.

1,853

1,179

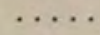

$\frac{\cdots \cdots}{33,538}$

$\begin{array}{r}\text { Acres } \\ 7,928 \\ 1,672 \\ 666 \\ 565 \\ 368 \\ 18 \\ \hline 10,617\end{array}$

Acres

31,492

8,434

1,919

1,744

368
18

33,538

Total area of county surveyed was 151,261 acres, $29 \%$ of it wooded.

\section{Alexander County}

Timber west of $\begin{array}{lll}\text { M. \& O. R. R. to Timber east of } & \text { Total area of } \\ \text { Mississippi } & \text { M. \& O. R. R. } & \text { timber types }\end{array}$ Mississippi
Bluffs

Type

Acres

No. $1 \mathrm{~B} . \ldots \ldots \quad 214$

No. $2 \mathrm{~B} \ldots \ldots$. . .

No. $1 \ldots \ldots \ldots$

No. $2 \ldots \ldots$.

Cull..........

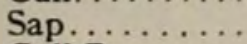

Cull B.......

Sap. B ......

$$
21,083
$$

1,583

6,816
36

.....

$$
\frac{\cdots \cdots}{29,732}
$$

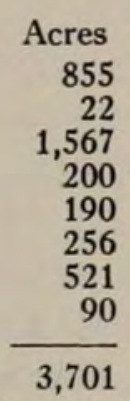

Acres

1,069
22

22,650

1,783

7,006

292

521

90

33,433

Total area of county surveyed was 114,193 acres, $29.2 \%$ of it wooded.

Jackson County

Timber west of

M. \& O. R. R. to Timber east of Total area of Mississippi $\quad$ M. \& O. R. R. timber types

\section{Type}

No. $1 \ldots \ldots$.

No. $2 \ldots \ldots \ldots$.

Cull..........

Sap............

No. 1 B.......

Sap. B .......

No. 2 B.......

\section{Bluffs}

\section{Acres}

41,307

\section{1,595}

1,202

1,059

-...

$\cdots \cdots$

$\frac{\cdots \cdots}{45,163}$

Acres

$\begin{array}{r}\text { Acres } \\ 10,427 \\ 346 \\ 60 \\ 9,154 \\ 10,749 \\ 477 \\ 465 \\ \hline 31,678\end{array}$

Acres

1,941

1,262

10,213

10,749

477

465

76,841

Timber on

Fountain Bluff

\section{Type}

Acres

Cull......

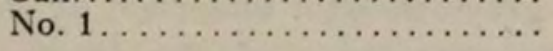

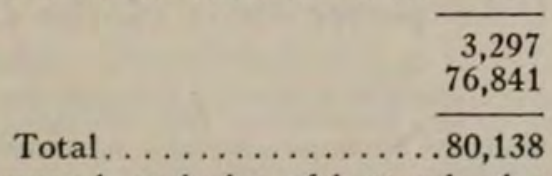

Total area of county surveyed, exclusive of bottomland, was 275,559 acres, $29 \%$ of it wooded. 
Summary of Foregoing Detall

TOTAL OF TIMBER BY TYPES AS SHOWN ON OUR MAP OF THE REGION

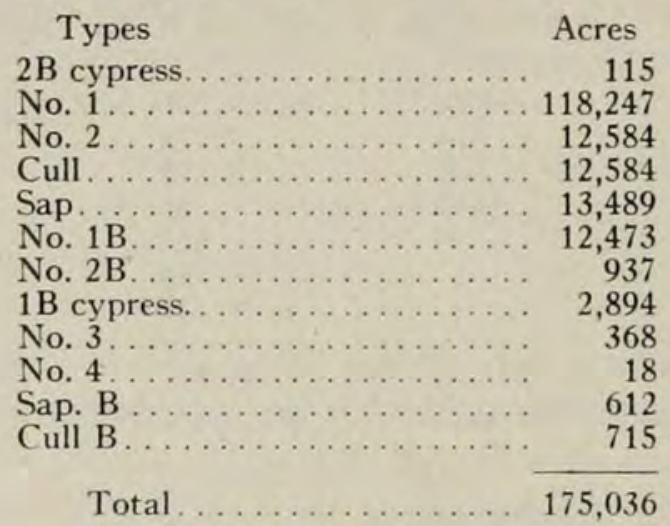

IMPORTANT TREES AND THEIR MAIN USES

\section{Hardwoods*}

List of white oaks:-

Quercus alba. White oak.

Quercus platanoides. Swamp white oak.

Quercus macrocarpa. Bur oak.

Quercus michauxii. Cow oak.

Quercus minor. Post oak.

The "White Oaks."-This group includes not only Quercus alba but swamp white oak, bur oak, cow oak, and post oak. The main distinction between the two groups of oaks, white and black, lies in the structure of the wood. In white oaks the large spring pores are plugged with a growth from the surrounding parenchyma cells known as tyloses, while the pores in the summer wood are thin-walled and angular. In the black or red oak group the walls of the spring pores are without tyloses, while the summer pores are thick-walled and more nearly circular in crosssection. The white oak $(Q . a l b a)$ is marketed for saw and veneer logs, wagon stock, tight cooperage, interior finish, furniture, and flooring, the poorer grades going into railroad ties, mine timbers, and cross bars. Swamp white, bur oak, and cow oak are marketed in the white oak group, as their wood is of equal quality and durability. Post oak is used largely for posts and mine timbers. It grows on flat ridge-tops known as "post oak flats," and on light gray silt-loam underlaid by tight clay which characterizes some of the poorer lands of the Ozark region. Black-jack

*According to the use of the term by foresters, a hardwood tree is one that has broad leaves, while the term softwood refers only to a needle-leaved tree, or conifer. As used in veneer and allied trades in this region and by woodsmen and lumbermen generally, the term softwood includes such trees as cottonwood, soft maple, sycamore, gums, and other bottomland species remaining after oak and cypress have been cut. As the forester uses the term, the only softwoods in southern Illinois are shortleaf pine, cypress, and red cedar. 
(Q. marilandica) is another inferior oak which comes in thickly on burned lands.

List of "black oaks":-

Quercus rubra. Red oak (sometimes called sour oak).

Quercus velutina. Black oak, yellow oak.

Quercus palustris. Pin oak, water oak.

Quercus coccinea. Scarlet oak.

Quercus falcata. Spanish oak (around Vienna).

Quercus imbricaria. Shingle oak (leaves resembling those of willow oak).

Black Oak or Red Oak Group.-The main trees coming under the red oak group, as it is generally called, are red oak, black oak, pin oak, scarlet oak, Spanish oak (around Vienna), and shingle oak.

These oaks go into the furniture and veneer trade; but with the development of wood preservation it has been found that red oak ties can be made as durable as white oak by the use of creosote or zinc chloride. The pin oak ( $Q$. palustris), often called water oak, and the shingle oak (Q. imbricaria) are sold as black oaks, although the latter is more properly classed with the willow oaks.

Liriodendron tulipifera. Yellow Poplar. Tulip-tree.-The tulip-tree is more likely to be found in the cooler ravines and small coves, along with beech and white oak, or in small undrained depressions where the seed finds proper light and germinating conditions, as it is intolerant of shade. Seedlings of this tree are also found in old fields which are growing up to sassafras and persimmon, where the soil has started to erode along the ravines. It makes an ideal wood for all kinds of exterior housefinish, such as siding, porch columns, and cornice, taking paint and resisting the weather remarkably well. In this region it is more likely to be used for veneers for baskets or sawed into rough lumber. The wood works easily and is sought by cabinet-makers for this reason. It can be distinguished from the cucumber-tree by the fact that its vessels are of the pitted variety, while those of the cucumber-tree are scalariform-a character to be made out only by the use of a compound microscope on the tangential surface of the wood. It is a tree of rapid growth and should be encouraged wherever there are seed trees and favorable conditions.

Fagus grandifolia. Beech.-This is a tree which does well in shade, and hence grows on the northern slopes, along with hard maple. We could not find that it discriminates between limestone soils and cherty soils, as it is found on both. The beech has a heavy, strong wood, resembling birch and hard maple, but it can be distinguished from either of them by the fact that the pith rays are quite distinct and about twice as wide as the diameter of the largest spring pores. Within the last few 
years the woods of this region have been culled for beech, since, when sent to the treating plant, it makes a good railway tie; and it is also sawed for car stock and switch ties. Heavy cutting makes light and moisture conditions unfavorable for beech, hence with rare exceptions it reproduces largely by root suckers, and is generally replaced in the new stand by more xerophytic species, such as black oak and hickory. There is still considerable beech around Alto Pass in woods which have not been burned over, because of moister conditions of the leaf litter.

Hickories. (Genus Hicoria.)-While there are several species of hickory in this region the classification of some of which gives trouble to the botanist, no distinction is made in the lumber.

Hicoria ovata. Shagbark or Shellbark Hickory.-This tree is easily recognized by the bark, which exfoliates in long strips. The leaflets are three to five, ovate to obovate in shape, hairy beneath when they unfold and usually until maturity, but sometimes almost glabrous. The nut is small and sweet-one of the best of the hickory-nuts coming into our markets. Hickory is strong, but not durable in the ground, and is used principally for carriage and wagon stock, handles, and sucker rods, while young saplings are used for hoop-poles and rustic furniture. The old distinction in the trade by which only the white sap-wood was used for wagon parts or spokes has disappeared, since the brown heartwood is normally just as strong as the sap-wood. Hickory sprouts vigorously when the younger trees are cut and its sprouts are very fire-resistant, so that it is forming a larger and larger proportion of our southern Illinois upland forests.

Hicoria laciniosa. Big Shellbark Hickory.-This hickory, also known as the big scaly bark hickory, is found in the bottoms, often associated with the shellbark hickory. The nuts are very much larger and harder to crack than those of the latter species. Its wood has similar properties and its uses are the same as those of the shellbark, although its bark, according to Professor Trelease, is usually less shaggy.

Hicoria pecan. Pecan Hickory.-This species belongs to the water hickories, having from 9-17 leaflets, and buds which resemble those of the bitternut hickory. It is found on bottomlands subject to overflow, and in some parts of the region under discussion specimens are left standing in the fields on account of the value of their crop of nuts. When other trees in the woods are removed from around pecan the crown spreads, making it more valuable for nut production. Its wood is the poorest of all the hickories.

Hicoria minima. Bitternut Hickory.-This is also one of the water hickories and can usually be identified by the more numerous and narrower leaflets, and by the twigs and buds-both of which are sometimes 
coated with a glandular yellow pubescence. The fruit sometimes has prominent sutures often slightly toothed, which split to a little below the middle of the nut. The kernel is bitter and not edible. It usually grows in moist situations along streams. The wood is white and the bark smooth.

Hicoria glabra. Pignut Hickory.-According to Trelease ('96) the typical eastern pignut hickory (Carya porcina), with nearly indehiscent husk, does not occur west of the Alleghanies, being replaced by the variety odorata. Dr. Trelease divides the species glabra into three varieties: odorata, the bark of which resembles that of the elm, being deeply ridged but not shaggy, with often nearly red twigs; villosa, a hill form with hairy twigs, with a bark resembling that of the persimmon tree; and microcarpa, which has a bark often as shaggy as the shagbark, and a nut usually gray to whitish, angled, and having a sweet kernel. The varieties odorata and microcarpa shade into each other, making their separation difficult. The wood of all the so-called pignut hickories differs little in character and may be used for wagon stock, spokes, handles, etc. In southern Illinois it is often sawed into pieces about 6 feet square, long known as trolley poles for mines. It is also used for sprags and mine ties.

Morus rubra. Red Mulberry.-The red mulberry has a very durable wood and is classed in this particular with such woods as chestnut, catalpa, and sassafras. Mulberry grows on small, rich bottoms, and farmers when making a timber sale usually reserve the mulberry because of its value for fence posts, although we have seen it among mine timbers and in charcoal wood. The heartwood is orange to yellowish brown, becoming russet-brown upon exposure to the weather. The sap-wood is thin and nearly white. It somewhat resembles the wood of Osage orange, which it approaches in durability.

Liquidambar styraciflua. Red Gum.-This is a species which improved methods of seasoning and drying have converted into a valuable wood for interior finish, all kinds of furniture, cooperage, and thin veneers suitable for crates and berry boxes. In the trade it is known as "satin walnut" owing to the fineness of its texture, the best grades going into veneer logs for furniture and interior finish. The wood is close-grained and tough, the color reddish brown, often with irregular dark streaks which make it valuable for doors and paneling. The tree is usually recognized by the star-shaped leaf and by its peculiar pronged fruits on long stalks.

Nyssa aquatica. Tupelo.-This is one of the most characteristic trees of the Mississippi and Cache river bottoms, where it is associated with such trees as the red gum, cypress, swamp white oak, and black gum, Nyssa sylvatica. There is very little distinction in color between the heartwood and sap-wood, although the former is sometimes 
cream-colored and is always the more durable. Former difficulties in seasoning this wood have been overcome, so that now it makes a fairly good lumber for floor mouldings, wagon-box boards, furniture, and veneer and interior finish. Preservative treatment makes it valuable for railroad ties and it is also a good wood for paper pulp and charcoal for gunpowder. It is sometimes sold in Europe under the name of bay poplar.

Nyssa sylvatica. Black Gum.-This tree is readily recognized by the fact that its leaves turn red or scarlet earlier than those of any other species, and that its branches come out almost at right angles to the stem. Its associates are about the same as those of the tupelo and its uses are similar. Its greatest economic development in Illinois is in its use for the manufacture of egg crates. Its wood is tough and fibrous, making it very hard to split, and it is not durable in the ground unless treated. It is one of the species which comes in great numbers after the logging of cypress, and men who have purchased land for cypress alone have found it becoming valuable on account of the spontaneous growth of black gum, tupelo, and red gum.

Pinus echinata. Shortleaf Pine.-It may be a point of interest to botanists to know that there is a stand of shortleaf pine in Illinois on an area commonly referred to as the "pine hills," a ridge above Wolf Lake Station, and paralleling Wolf Lake. This is an old ox-bow lake fed by springs and too deep to be successfully drained. Its location is shown on our map, and one of the plates in this report shows the character of the stand of timber, as well as a $\log$ house which is built entirely of shortleaf-pine logs. Judge Karraker, of Jonesboro, tells us that at one time a considerable number of logs were cut on these hills and sawed into boards. The soil is a dry cherty loam and, largely because of fires, the timber is not spreading, although trees of pole size are found in many places. The species can be identified by the needles, which are only about half as long as those of the longleaf pine (Pinus palustris), and by the bark, which at maturity is scaly and yellowish red, in very pronounced irregular plates. The nearest out-state location of this species is in Missouri, where it is mixed with hardwoods-mostly white, red, black, and black-jack oak.

Taxodium distichum. Bald Cypress.-The bald cypress is of considerable importance in Illinois, occurring in the bottoms of the Mississippi River, near McClure, and in those of the Cache River and the backwater's of the Ohio. In some small areas it occurs in pure stands; and elsewhere it is mixed with gums and other hardwoods. It has been rather closely culled out of the Cache River bottoms, the largest mill sawing cypress in quantities being that of Main Brothers, at Karnak, just outside this region. There is also a mill at Ullin belonging to the Defiance Box Company, of Defiance, Ohio, which saws some cypress into 
box boards for crockery crates. Main Brothers use the drainage ditches to float cypress to the mill. This species is easily recognized by its buttressed base and "cypress knees," and by the way in which it towers above the other swamp species. Reproduction is at too low an ebb to produce another crop after the present one is cut, and it is being succeeded by hardwoods.

Juniperus virginiana. Red Cedar.-This tree, of some importance for fence posts, often occurs in pure stands on limestone outcrops along river bluffs and scattered over old pastures. Some 235 stem analyses of this tree were made by the State Natural History Survey in co-operation with the State Department of Agriculture to determine its rate of growth under different conditions. It is injurious in fruit regions because it bears the teleutospore stage of the apple rust in the so-called cedar apples.

Fraxinus americana. White Ash. Gray Ash.-The white ash is found as a bottomland species, associated with such trees as beech, sugar maple, linden, elm, and red oak, preferring openings where there is considerable light. In such situations and with good soil conditions it produces a tall clean stem. The sap-wood is white and the heartwood light brown, the wood being heavy, hard, strong, and elastic. Its main uses are for handles, athletic goods, butter-tubs, car and vehicle stock, automobiles, and implements. Like hickory, the second-growth ash is stronger than old growth, because of the larger proportion of fiber in the summer wood. Clear ash down to a length of four feet can be sold in the form of bolts for handles.

Fraximus lanceolata. Green Ash.-The green ash is found in wetter situations than white ash, with such trees as white elm, red and silver maple, cottonwood, aspens, linden, and even with cypress. The wood is similar to that of white ash but is inferior in mechanical properties. It succeeds well in plantations, but is subject in this state to injury by the oyster-shell scale.

Acer saccharum. Hard Maple.-This is one of the best of the maples and is commonly associated with beech in the shadier situations, maple being very tolerant of shade. Hard maple is a good wood for furniture, flooring, and interior finish, and makes a good railway tie when treated. It is also suitable for the manufacture of basket veneers, and in this region most of it goes into the market for this purpose. Natural reproduction only takes place in shady, moist situations, such as are found in some of the ravines and small bottoms along streams.

Acer saccharinum. Soft Maple.-This tree occurs in the bottoms along with sycamore, elm, hackberry, and gums, and is used largely for veneers and railroad ties. It grows well from sprouts and should be successfully raised on the coppice system for charcoal. From the silvery appearance of the under side of the leaf it is sometimes called the "silver 
maple." The wood is lighter in weight than that of hard maple, but it is a much more rapid grower. Some very large maples were found in bottomlands of this region, one being measured near Ware, growing near the drainage ditch on the Spann tract, which scaled 1,173 board feet.

Differences between Hickories (Hicoria) and Walnuts (Juglans).Both these genera belong to the family Juglandaceae but can be distinguished by the fact that most of the hickories have nuts with a dehiscent husk splitting into four parts, or, if not, the husk splits part way down by following the ridges or sutures, while the butternut and the walnut must be "hulled" to get at the nuts. Both genera are alike in having compound leaves but different in the fact that the walnut and butternut twigs have a pith with black partitions across them, while the hickories have the ordinary unchambered pith, like the ash.

Juglans nigra. Black Walnut.-Black walnut was found as a scattered tree in the small bottoms of this region and sometimes along pastured ravines on farms, but it reaches its best development in the rich bottomlands of the Mississippi River, where it often occurs with pecan. Walnut is one of our most valuable woods for furniture and veneers, and burled specimens are found which have a grain resembling Circassian walnut. During the war it was sought for gun stocks and aeroplane propellers, and the dark brown heartwood ranks in durability with that of white oak and black locust. Prices for clear logs at the present time run from $\$ 40$ to $\$ 150$ a thousand feet, f.o.b. cars. Walnut should only be planted on good, rich bottomland, as it does very poorly on yellow silt loam soils.

Juglans cinerea. White Walnut.-An occasional tree of this species is found along streams and banks of ravines, a well-drained gravelly soil being preferred. It is easily distinguished from the black walnut by its grayer bark, by its clammy, almost sessile leaflets, and by the fact that the twigs, buds, and young fruits are covered with a glandular pubescence. The wood in microscopic structure can hardly be distinguished from black walnut, both being classed as "diffuse-porous" woods-that is, there is no marked contrast between the size of spring and summer pores as there is in oaks, ash, and chestnut, which are classed as "ring-porous" hardwoods. The heartwood is a light chestnut-brown, takes a good polish, and is easily worked, so that it is preferred by cabinet makers for the lining and sides of drawers. The nuts are edible and their hull contains a juice which was used by the pioneers for dyeing carpet-rags and clothing.

Magnolia acuminata. Cucumber-tree.-This is one of the magnolias whose range extends northward into the southern Illinois bottomlands. It grows in undrained swamps along with cottonwood, soft maple, tupelo, 
and black gum. Its wood can scarcely be distinguished from that of the tulip-tree, and it is used for the same purposes. It can be identified by the long pointed buds and by the fruit, which after the fall of the petals grows from the center of the flower to about the size and in the shape of a small cucumber.

Gleditsia triacanthos. Honey Locust.-There are two species of Gleditsia in our district, triacanthos and aquatica, the latter having been found in the woods around Ullin. The first mentioned is the more important commercial species, and is easily recognized by the long-branched thorns on trunk and branches, by the compound leaves, and by the long pods containing hard, dark-brown seeds. The heartwood is classed along with the larch for durability. The species is used for railroad ties, lumber, and charcoal. The wood has a pleasing grain when quarter-sawed, but in durability it does not rank with the black locust.

Tilia americana. Basswood.-This is primarily a tree of the river bottoms, where it is associated with elms, hackberry, tulip-tree, and black cherry. The wood is used for wooden-ware, carriage bodies, high-grade trunks and boxes, backing and drawers for furniture, excelsior, and matches. It is light but strong, resembling cottonwood. The genus Tilia may be known by the fruit, which consists of two or three nutlets attached to a foliar expansion which assists in scattering the fruit.

Sassafras sassafras.-This is a common tree coming in on old fields, along with persimmon and sumach. It can be identified by the frequently mitten-shaped leaves and the aromatic odor of the inner bark. Its heartwood is brown and very durable, so that it is used for fence posts, cooperage, and boat building. Its roots are used for tea.

Robinia pseudacacia. Black Locust.-This tree is quite common in the Ozark region, on slopes above the Ohio River, where it is not attacked by the locust-borer, which is so destructive to pure stands. The wood is strong, and in durability ranks with Osage orange, from which it is not easily distinguished except by the yellower color of the former. It is used for fence posts, telephone poles, and insulator pins, and during the war it was largely utilized for tree nails and for fastening together the parts of wooden ships. The destructiveness of the locust-borer makes it inadvisable to plant this species in southern Illinois, although it is one of the best trees for reclaiming worn-out soils subject to gullying, or for holding blow sand.

Prumus serotina. Wild Black Cherry.-Occasional specimens of this tree are found in bottomland forests. It can be recognized by the bark, which is broken up into square plates, and by its fruit, which grows in racemes. The heartwood is of a deep wine-red color, and fine in both grain and texture. It is a valuable cabinet, and an excellent propeller, 
wóod. It is used for fixtures, backing for cuts, car finish, professional and scientific instruments, furniture, handles, and brushes. It has a pleasing, though not striking, effect when quarter-sawed, and its advantage for furniture lies in the fact that it becomes deep red when varnished without any stain. The wood is durable in the soil.

Celtis occidentalis. Hackberry.-This species, as well as another of the genus (Celtis mississippiensis), is found in this region. It can be identified by the leaves, which resemble those of the elm, by the sweet berry, which is largely seed, and by the wart-like excrescences on the bark. Its wood, like that of the elm, is very hard to split. The sap-wood is lemon-yellow, and is hard to season without its splitting. It has no especial merit as lumber, but it is sometimes used for fence boards and is quite commonly made into railroad ties, which have to be treated, however. It can be classed as a bottomland species in this region, growing on land subject to overflow.

Ulmus americana. American Elm. White Elm.-This is the commonest of the elms in southern Illinois, although we also have the slippery elm, (Ulmus pubescens) and the winged elm (Ulmus alata). Ulmus serotina has been reported by Ridgway in the extreme northeast corner of Wayne county, but we have not yet found this species. The white elm is found in meadows where there is considerable seepage and in rich bottomland wood, where it reaches an immense size. One was measured on the Spann tract, in Union county, which was 30 inches in diameter breast-high, and scaled 921 board feet. Its total height was 60 feet and its merchantable length 42 feet. Such trees are used in the manufacture of rotary-cut veneer for baskets and coiled hoops; many of them go into railroad ties.

Red or slippery $\mathrm{elm}$ has more pubescent leaves and fruit than white elm, a pinkish, more durable wood, and is used for the same purposes.

The winged elm has smaller leaves than other species and the twigs have prominent ridges of cork to which it owes its name.

Populus heterophylla. Szwamp Cottonwood. Black Cottonzwood. Swamp Poplar.-This tree reaches its best size in river swamps along with red gum, soft maple, cucumber and tulip, attaining diameters of 4 to 6 feet, with very thick deeply ridged bark. According to Deam ('21), of Indiana, the pith of the shoots of this species is orange, while in all of the other cottonwoods it is white. The wood is white, light, and tough, and fairly easy to work, undergoing indentation without splitting. It is a valuable box and crate material, especially for eggs. It is also used for wagon-box boards, veneer, excelsior, paper pulp, and as match stock. Cottonwood thrives best in full sunlight, and for this reason readily gains a footing in old corn fields along the Mississippi River and on sand-bars 
with willow and sycamore. It is a prolific sprouter and if there were pulp mills in this region it could be raised profitably by the coppice method on a twenty-year rotation.

The common cottonwood (Populus deltoides) may be classed with this species so far as commercial uses are concerned. Both are grown easily from cuttings on overflow lands.

Platanus occidentalis. Sycamore.-This tree grows along streams in bottomlands and on sand-bars with willow and cottonwood. It is easily identified, even at a distance, by the green and white spotted bark and by the fruit, known as the buttonball, which is simply a head-like mass of seeds. The wood of sycamore gives a pleasing grain for interior finish when sawed radially, but most of it goes into veneer logs, ordinary dimension lumber, and railroad ties. It is also used for plug-tobacco boxes, and butcher blocks. It grows rapidly on overflow land, both from seedlings and sprouts, and might do well on gullied lands which are not too dry. The largest sycamore in the country is reported by Robert Ridgway ('82), of Olney, Illinois, as growing not far from Mt. Carmel, Ill., in the Wabash bottoms. His measurements show that it had a height of 160 feet, a diameter of 15 feet above the swell of the base, and a spread of 134 feet, making it probably the largest tree of any species east of California.

Salix nigra. Black Willow.-The black willow is prevalent along practically the whole course of the Mississippi and this species and the cottonwood are as a rule the first trees to appear on sand-bars and islands. Willow is a very light wood, with the sap-wood whitish to creamy yellow and the heartwood pink to reddish brown. The annual rings of all willows are relatively indistinct, and the wood is quite uniform throughout. Under the microscope black willow can be distinguished from the white by the tendency of the pores in the late wood to form wavy tangential lines. Willow wood is used for lumber, slack cooperage stock, excelsior, charcoal, pulp, artificial limbs, baskets, and fence posts. It is easily raised for revetment work and basketry by the system of pollarding. After cypress is cut in the Cache River bottoms there is a large amount of willow left which on a short rotation would be profitable for charcoal.

Dogwood, Persimmon, Redbud, Hop Hornbeam, and Blue Beech.These trees are of common occurrence but can not be rated as of much economic importance. Dogwood, (Cornus florida) forms an under story in some forests and is quite prominent after a cutting-over of the woods. Persimmon (Diospyros virginiana) grows in old fields and along roadsides and, with dogwood, might be used for shuttle blocks. Its heartwood is black and known as "American ebony." Redbud or Judas tree (Cercis canadensis) with its characteristic purple flowers, is found in bottomland woods along with dogwood, and may be recognized by its 
small pods and simple leaves. An occasional hop hornbeam (Ostrya virginiana) occurs on slopes along streams, and may be known by its hop-like fruit and by its bark, which exfoliates something like that of a red cedar. Blue beech (Carpinus caroliniana) is another small tree, with grayish bark and fluted stem, growing along small streams, and may be recognized by its fruit, which consists of a small nutlet at the base of a three-cleft bract. Both of these latter species may be classed as weed trees and should be removed to give room for more valuable species. Hop hornbeam, on account of its hardness and strength, is used for skids, handspikes, and wooden wedges.

Tabulated data obtained by a study of types of upland and bottomland timber follow. 
Table 1.-Numbers of Trees of Various Species* (Upland Type) on an Average Acre Based on 117.18 ACres, Alto Pass

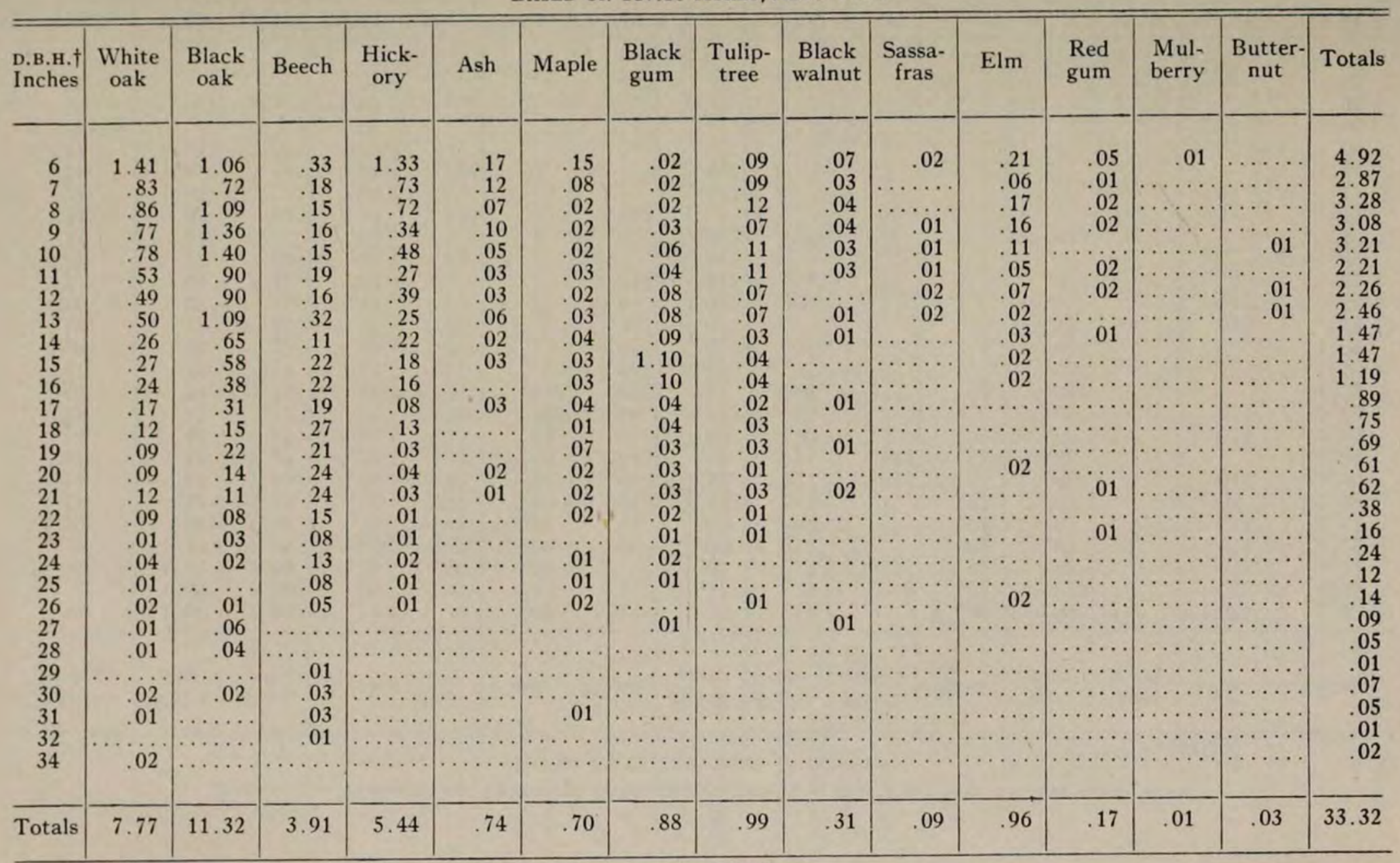

*Used, of course, in the sense of sort or kind. †Abbreviation for diameter breast-high. 
Table 2.- Numbers of Trees of Various Species (Upland Type) on an Average Acre BAsed ON 65.14 ACres, Jonesboro

\begin{tabular}{|c|c|c|c|c|c|c|c|c|c|c|c|c|c|c|}
\hline $\begin{array}{l}\text { D.B.H. } \\
\text { Inches }\end{array}$ & $\begin{array}{c}\text { White } \\
\text { oak }\end{array}$ & $\begin{array}{c}\text { Black } \\
\text { oak }\end{array}$ & Beech & $\begin{array}{l}\text { Hick- } \\
\text { ory }\end{array}$ & Ash & Maple & $\begin{array}{c}\text { Black } \\
\text { gum }\end{array}$ & $\begin{array}{c}\text { Tulip- } \\
\text { tree }\end{array}$ & $\begin{array}{c}\text { Black } \\
\text { walnut }\end{array}$ & Elm & $\begin{array}{l}\text { Red } \\
\text { gum }\end{array}$ & $\begin{array}{l}\text { Bass- } \\
\text { wood }\end{array}$ & Misc. & Totals \\
\hline $\begin{array}{r}6 \\
7 \\
8 \\
9 \\
10 \\
11 \\
12 \\
13 \\
14 \\
15 \\
16 \\
17 \\
18 \\
19 \\
20 \\
21 \\
22 \\
23 \\
24 \\
25 \\
26 \\
27 \\
28 \\
29 \\
30\end{array}$ & $\begin{array}{c}1.67 \\
1.09 \\
1.12 \\
.88 \\
.88 \\
.58 \\
.57 \\
.58 \\
.46 \\
.41 \\
.29 \\
.28 \\
.20 \\
.17 \\
.08 \\
.09 \\
.12 \\
.015 \\
.05 \\
.05 \\
.015 \\
.015 \\
\ldots .0 \\
.015 \\
\ldots .\end{array}$ & $\begin{array}{r}1.85 \\
1.80 \\
2.06 \\
1.98 \\
1.75 \\
1.38 \\
1.66 \\
1.29 \\
.95 \\
.77 \\
.57 \\
.51 \\
.27 \\
.26 \\
.15 \\
.11 \\
.06 \\
\ldots . .15 \\
\ldots \ldots \\
\ldots .015 \\
\ldots \ldots \\
\ldots \ldots \\
\ldots \ldots\end{array}$ & $\begin{array}{l}11 \\
.06 \\
.20 \\
.12 \\
.26 \\
.17 \\
.26 \\
.26 \\
.34 \\
.28 \\
41 \\
.38 \\
.40 \\
.17 \\
43 \\
.23 \\
.21 \\
.12 \\
.12 \\
.06 \\
.08 \\
.05 \\
08 \\
06 \\
015\end{array}$ & $\begin{array}{r}1.26 \\
.91 \\
.90 \\
.80 \\
.44 \\
.37 \\
.40 \\
.34 \\
.23 \\
.25 \\
.23 \\
07 \\
.03 \\
.06 \\
.05 \\
.03 \\
.08 \\
\ldots .015 \\
.015 \\
\ldots .015 \\
\ldots \ldots \\
\ldots \ldots \\
\ldots \ldots \\
\ldots \ldots\end{array}$ & 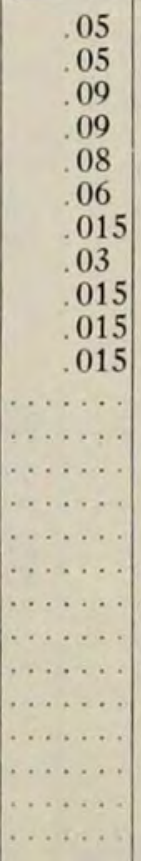 & 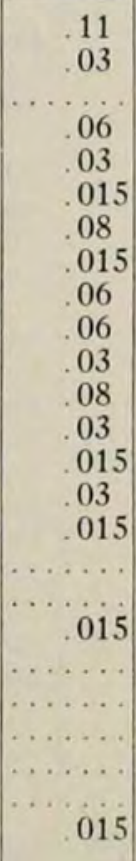 & $\begin{array}{r}.09 \\
.21 \\
03 \\
05 \\
.06 \\
.14 \\
.12 \\
.09 \\
.09 \\
.015 \\
.11 \\
12 \\
.015 \\
.015 \\
.015 \\
.015 \\
.015 \\
.015 \\
\ldots .015 \\
.015 \\
\ldots \ldots \\
\ldots \ldots \\
\ldots \ldots \\
\ldots \ldots\end{array}$ & 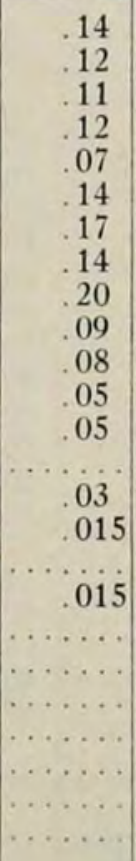 & 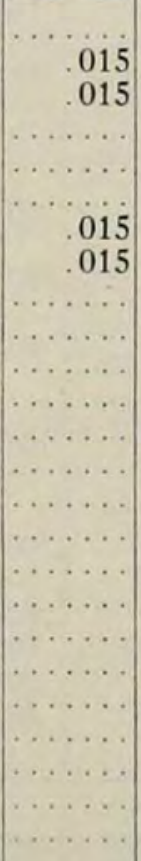 & 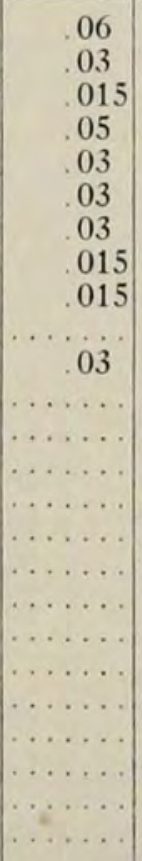 & $\begin{array}{l}.04 \\
.015 \\
.05 \\
.05 \\
.03 \\
.03 \\
.06 \\
.06 \\
.05 \\
.09 \\
.015 \\
.06 \\
.015 \\
.05 \\
\ldots .015 \\
\ldots \ldots \\
.015 \\
\ldots \ldots \\
\ldots \ldots \\
\ldots \ldots \\
\ldots \ldots\end{array}$ & 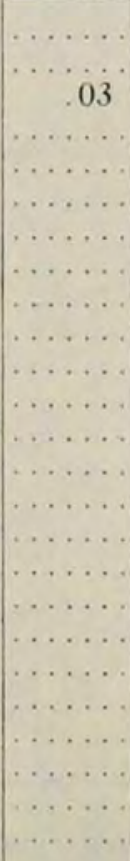 & 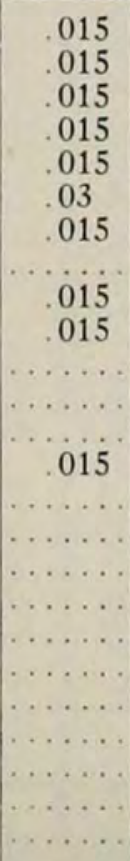 & $\begin{array}{l}5.40 \\
4.34 \\
4.64 \\
4.21 \\
3.65 \\
2.95 \\
3.39 \\
2.84 \\
2.43 \\
2.00 \\
1.78 \\
1.55 \\
1.01 \\
.75 \\
.78 \\
.52 \\
.49 \\
.18 \\
.21 \\
.12 \\
.12 \\
.08 \\
.08 \\
.08 \\
.03\end{array}$ \\
\hline Totals & 9.63 & 17.45 & 4.88 & 6.48 & .51 & .69 & 1. 26 & 1.54 & .06 & .31 & .64 & .03 & .17 & 43.65 \\
\hline
\end{tabular}


Table 3.-Estimate, by Species, of Board Feet in Stands (Upland Type) at Both Alto Pass and Jonesboro. Average for 182.32 ACres (BASEd on Data in Tables 1 and 2.)

\begin{tabular}{|c|c|c|c|}
\hline & Species & Alto Pass & Jonesboro \\
\hline - & 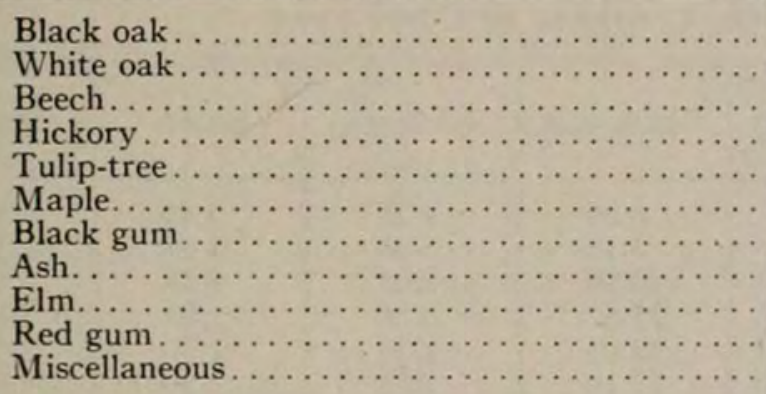 & $\begin{array}{r}608 \\
525 \\
415 \\
351 \\
124 \\
128 \\
114 \\
42 \\
40 \\
14 \\
41\end{array}$ & $\begin{array}{r}592 \\
357 \\
433 \\
238 \\
97 \\
58 \\
75 \\
29 \\
18 \\
37 \\
14\end{array}$ \\
\hline & Totals $\ldots \ldots \ldots \ldots \ldots \ldots \ldots \ldots$ & 2,362 & 1,948 \\
\hline
\end{tabular}

It can be seen from these figures that the species in order of importance are black oak, white oak, beech, and hickory, in both regions, followed by maple, tulip, and black gum. Species of minor importance are ash, elm, and red gum, with a few others such as walnut, mulberry, sassafras, butternut, and hackberry occurring only occasionally.

Combining the results obtained on the 182.32 acres at Alto Pass and Jonesboro, we get the following table of yield by species in board feet, with the per cent of the entire amount that each forms.

TABLE 4

\begin{tabular}{|c|c|c|}
\hline & Board ft. per acre & Per cent of stand \\
\hline Black oak. & $\ldots \ldots 603$ & 27.6 \\
\hline White oak... & $\ldots \ldots \quad 465$ & 20.8 \\
\hline Beech........ & $\ldots \ldots \quad 404$ & 18.1 \\
\hline Hickory.. & $\ldots \ldots$ & 14.1 \\
\hline Tulip... & $\ldots \ldots$ & 5.1 \\
\hline Maple........ & $\ldots \ldots$ & 4.6 \\
\hline Black gum... & … 100 & 4.5 \\
\hline Ash.......... & $\ldots \ldots \quad 37$ & 1.6 \\
\hline Elm......... & $\ldots \ldots$ & 1.4 \\
\hline Walnut...... & $\ldots \ldots$ & 1.0 \\
\hline Red gum.... & $\ldots \ldots$ & \\
\hline Miscellaneous & $\ldots$ & .004 \\
\hline Total. & $\ldots 2,228$ & 99.834 \\
\hline
\end{tabular}


The stand in cubic feet for the average acre for both tracts combined, by species, is given in the following table.

Table 5.-Volume by Species on an Average Acre, Upland Type (BASED ON THE 182.32 ACRES)

Total Contents in Cubic Feet

\begin{tabular}{|c|c|c|c|c|c|}
\hline $\begin{array}{l}\text { D. B. H. } \\
\text { Inches }\end{array}$ & White oak & Black oak & Hickory & Beech & Tulip-tree \\
\hline $\begin{array}{r}6 \\
7 \\
8 \\
9 \\
10 \\
11 \\
12 \\
13 \\
14 \\
15 \\
16 \\
17 \\
18 \\
19 \\
20 \\
21 \\
22 \\
23 \\
24 \\
25 \\
26 \\
27\end{array}$ & $\begin{array}{r}6.47 \\
5.47 \\
8.92 \\
9.02 \\
9.90 \\
7.97 \\
8.74 \\
11.07 \\
8.00 \\
12.48 \\
10.14 \\
10.23 \\
11.34 \\
9.23 \\
9.57 \\
8.03 \\
8.66 \\
10.08 \\
4.45 \\
3.21 \\
1.97 \\
1.49\end{array}$ & $\begin{array}{r}6.09 \\
7.18 \\
10.99 \\
12.52 \\
18.05 \\
17.10 \\
24.76 \\
29.75 \\
24.00 \\
23.78 \\
19.97 \\
20.29 \\
12.07 \\
15.60 \\
10.15 \\
8.80 \\
5.92 \\
.95 \\
1.75 \\
1.65 \\
4.62\end{array}$ & $\begin{array}{r}4.25 \\
5.08 \\
6.64 \\
6.65 \\
8.74 \\
8.76 \\
12.51 \\
8.92 \\
9.46 \\
11.55 \\
12.25 \\
4.68 \\
3.68 \\
2.34 \\
2.56 \\
1.89 \\
2.76\end{array}$ & $\begin{array}{r}5.50 \\
4.08 \\
4.78 \\
1.04 \\
2.30 \\
2.50 \\
3.46 \\
5.63 \\
5.94 \\
7.70 \\
12.71 \\
11.96 \\
14.00 \\
11.42 \\
22.00 \\
15.18 \\
13.14\end{array}$ & $\begin{array}{l}1.21 \\
1.47 \\
1.05 \\
1.62 \\
2.34 \\
5.00 \\
5.94 \\
5.86 \\
8.29 \\
6.57 \\
8.69 \\
6.44 \\
4.16 \\
4.06 \\
4.38 \\
3.28 \\
2.76\end{array}$ \\
\hline Totals & 176.44 & 275.99 & 112.72 & 143.34 & 73.12 \\
\hline
\end{tabular}

Grand total, 781.61 cubic feet, or 8.68 cords $(90 \mathrm{cu} . \mathrm{ft} .=1 \mathrm{cord})$.

Table 6.-Average Number of Board Feet per Acre, Bottomland Type

(Symbol, No. 2B*). Based on 13.63 ACres

\begin{tabular}{|c|c|}
\hline 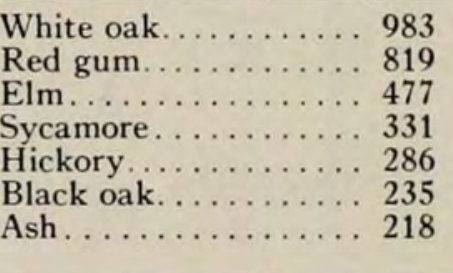 & 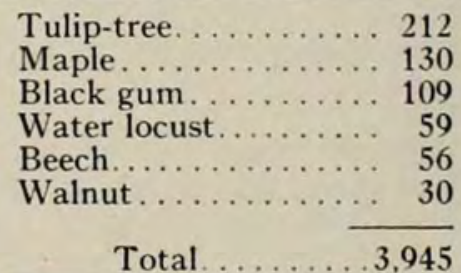 \\
\hline
\end{tabular}

N. B. - This bottomland tract of 13.63 acres averaged 33.38 trees per acre, but only those trees were measured whose D. B. H. (diameter breast-high) was 10 inches or more.

*For explanation of symbols see pages 298 and 299. 
Table 7.-Estimate, by Types, of Total Merchantable Timber for AREA MAPPED

\begin{tabular}{|c|c|c|c|}
\hline Type* & Acreage & $\begin{array}{l}\text { Average board feet } \\
\text { per acre }\end{array}$ & $\begin{array}{l}\text { Total board feet } \\
\text { for type }\end{array}$ \\
\hline \multicolumn{4}{|c|}{ UPLAND-131,217 ACRES } \\
\hline $\begin{array}{l}\text { No. } 1 \\
\text { No. } 2 \\
\text { No. } 3 \\
\text { No. } 4\end{array}$ & $\begin{array}{r}118,247 \\
12,584 \\
368 \\
18\end{array}$ & $\begin{array}{r}1,000 \\
3,750 \\
7,500 \\
12,000\end{array}$ & $\begin{array}{r}118,247,000 \\
47,190,000 \\
2,760,000 \\
216,000\end{array}$ \\
\hline \multicolumn{4}{|c|}{ BotToMLAND-16,419 ACRES } \\
\hline $\begin{array}{l}\text { No. 1B } \\
\text { No. 2B } \\
\text { 1B cypress } \\
\text { 2B cypress }\end{array}$ & $\begin{array}{r}12,473 \\
937 \\
2,894 \\
115\end{array}$ & $\begin{array}{l}1,000 \\
3,750 \\
1,000 \\
3,750\end{array}$ & $\begin{array}{r}12,473,000 \\
3,513,000 \\
2,894,000 \\
431,250\end{array}$ \\
\hline Totals & 147,636 acres & & $187,725,000$ board feet \\
\hline
\end{tabular}

ANNUAL CUT IN BOARD FEET

The total cut for the region under discussion and covered by our map is hard to estimate, but it was arrived at in the following manner: The best information obtainable was secured as to the amount of timber used by the veneer plants at Jonesboro, Anna, Cobden, and Dongolatowns which lie at the center of the fruit-producing section; the average railroad tie was figured as containing 33 board feet, and the estimate of timber going into them was based on returns from the various railroad companies as to the number of Illinois-produced ties requisitioned by them in 1921-a total of 913,940 . With this number as a basis for estimate it was assumed that southern Illinois in normal times produced 500,000 and that 300,000 of these at least would come from this region; the amount of sawed lumber was obtained by adding to the actual output of the large stationary mills an assumed amount for the smaller portable mills based on the actual number of days which they might run-which is quite a variable period; and the amount of mine timbers cut in the region and shipped to adjacent counties, upon which there is no definite check, was placed at 4,000,000 board feet. While the individual assignments are necessarily inexact we believe that the total, when made up as follows, is approximately correct.

Veneers $\ldots \ldots \ldots \ldots \ldots \ldots \ldots 2,000,000$ board feet

Cross-ties ...............10,000,000 " "

Sawed lumber ............. " " $4,000,000$ "

Mine timbers $\ldots \ldots \ldots \ldots \ldots \ldots, 4,000,000$ " "

Total $\ldots \ldots \ldots \ldots \ldots \ldots \ldots 20,000,000$ board feet 
Growth on the average acre, upland type.-Growth per cent on the average acre of upland timber was roughly figured by Pressler's formula,

$$
\frac{V-v}{V+v} \times \frac{200}{n},
$$

where $V$ equals the present volume on the average acre; and $v$, its volume $n$ or ten years ago. The merchantable volume at present was computed as 635.53 cubic feet and by figuring from growth tables the volume of each diameter class ten years ago, the total volume at that time was found to be 477.68 cubic feet. Using the formula, we get 2.87 as the growth per cent. This can be applied like simple interest to the present stand, giving the annual increment on the average acre as 18.05 cubic feet, or about $1 / 5$ of a cord per acre per annum. It would have been more exact to follow Recknagel's method (Recknagel, '16) and to have found a growth per cent for each diameter class, applying this as a percentage to get the increment on the volume of that diameter class and totaling these increments, but according to Chapman ('21) it is not safe to apply such a figure over large areas because the average age, thrift, or other conditions may differ widely from that of the sample area. If, however, this figure were applied to our 131,217 acres of upland merchantable timber it would give an annual increment of about $13,000,000$ board feet, assuming that a cubic foot is equivalent to 5.5 board feet.

Whether this growth of about $1 / 5$ of a cord per acre per year for upland timber is correct or not, it indicates that the annual growth is very low owing to poor stocking, to fires, and to lack of thinning at proper intervals. Baker ('21) cites an example of oak in the sandy region of southern New Jersey where a thinned acre had increased in volume at the rate of about one cord per acre per annum, whereas a check plot near it, not thinned, had only increased 1.1 cords in seven years. An improvement cutting in a stand of 20-year-old mixed hardwoods in the same state resulted in a gain of 9.4 cords per acre in 10 years, or, again, almost a cord per acre per year.

\section{Physiographic Features TOPOGRAPHY}

The area covered by this report may be divided for convenience into the Mississippi bottomlands and the interior highlands. The Mississippi bottomlands occupy about $18 \%$ of the total area of the 697,286 acres, with an average width of four and one-half miles. The relative width at two different places is shown on the Profiles sheet. This part of the area is cut by old river channels and is still subject to local overflows. Natural drainage is poor, the river having an average fall of only six or seven inches to the mile. 


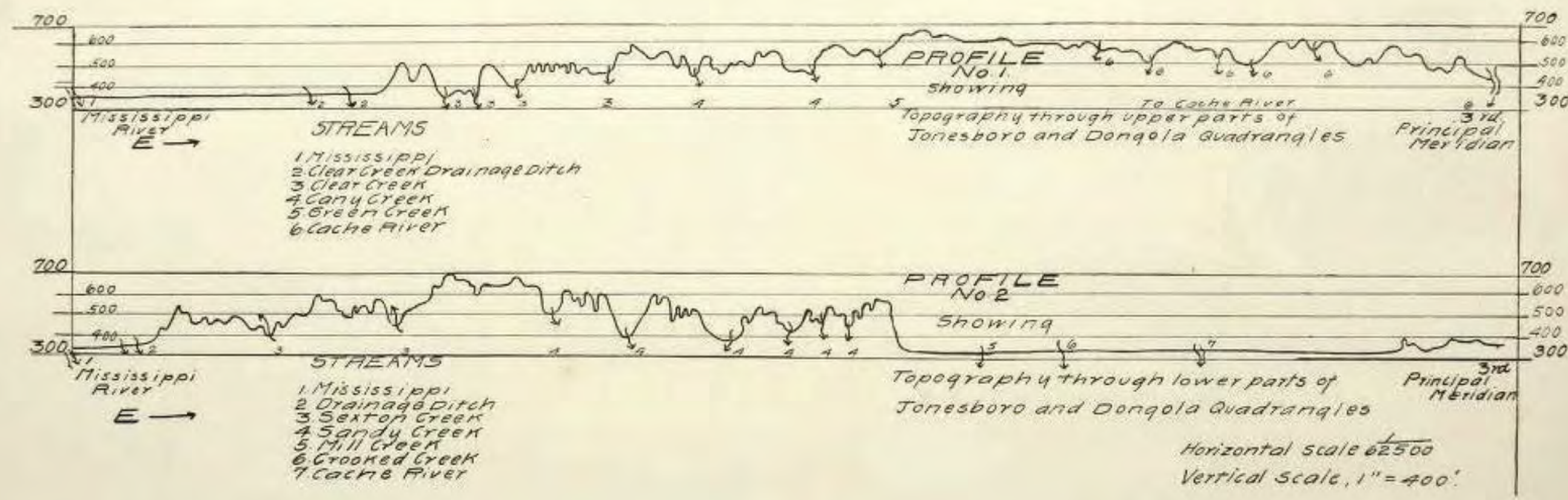


The former banks of the Mississippi rise abruptly above the floodplain to heights of 250 feet in places and this elevation continues across the southern part of the state as a part of the Ozark highlands. There is a north and south axis parallel to the Mississippi culminating near the western part of the Jonesboro quadrangle in bluffs which rise to the height of 700 feet in the north, increase to 880 feet in the middle portion, and decrease again to 700 feet in the southern section. A detached feature of these highlands rises like an island from the Mississippi plain at Fountain Bluff, but elsewhere they are continuous. The east and west axis ends in the chain of heights known as the Shawneetown hills, in Hardin county.

The highest point of our area is some six miles east of the western bluffs at Bald Knob, Union county, where the north and south axis is intersected by the Ozark east and west axis, reaching a height of 1,025 feet. Bald Knob, as already stated, is exceeded in height by Williams Mountain, in Pope county, and, again, by Charles Mound, in Jo Daviess county, but since Bald Knob overlooks the flat flood-plain of the Mississippi, its actual relief is probably much greater than that of the other two points.

Heavy erosion characterizes the western uplands, flanked as they are by the low Mississippi flood-plain. Innumerable short valleys with almost precipitous sides are found, separated by long, very narrow-topped ridges - a form of topography which does not readily lend itself to agriculture.

This minutely dissected upland occurs in a strip averaging five to ten miles in width. East of it the stream valleys are wider, the slopes less precipitous, and the ridge-tops broader, so that the eastern section is well adapted to fruit-growing and general agriculture. In the northeastern part, on the Big Muddy, and in the southeastern section, on the Cache River, wide flood-plains are found.

DRAINAGE

The northern and northwestern part of the region drains into Big Muddy River and its tributaries. Clear Creek, Dutch Creek, Harrison Creek, Horse Creek, and Sexton Creek break through the western bluffs into drainage ditches, emptying into the Mississippi River, while Mill Creek, Lingle Creek, Cooper Creek, and Sandy Creek, in the Jonesboro quadrangle, take their rise in the chert hills, and drain south or southeast into the Cache River. (See the Profiles sheet.) Geologists tell us that the Mississippi was at one time not the master stream, but that some of the streams now draining into it flowed south or southeast.

While the rock strata have in general a slope towards the southeast or east, faults have somewhat broken up the continuity of this slope. The fact that there is such slope can be brought out by comparing elevations 
prevailing at the western bluffs with those on the eastern border. At the north the difference in elevation is $300 \mathrm{feet}$, in the central portion about the same, and in the southern portion 260 feet.

GEOLOGY

A study of Plate LXXI, which was traced directly from the map of the State Geological Survey, will give a very good idea of the geology of this region from Thebes to Chester and west to the third principal meridian-the boundaries of the map. The oldest rocks are placed first in the legend. As we proceed eastward from the Mississippi we encounter successively younger strata, those laid down later in geological history. It should also be kept in mind that this whole region experienced periods of submergence beneath the sea, with a deposition of limestones, sandstones, or shales, depending upon the conditions of the inland waters, these periods of submergence alternating with periods of elevation and subsequent erosion down to base level so that where new layers of sediment were deposited upon the old eroded land forms, there are many examples of what the geologist calls "nonconformity."

The Ordovician and Silurian, which are the oldest rocks exposed by erosion in Union and Alexander counties, lie like a thin wedge between the Quaternary deposits on the west and the Devonian on the east, running north and south from Fayville to Reynoldsville, and consist mostly of limestones, sandstones, and shales. Since these Pre-Devonian rocks have been fully described by Savage ('08, '09, '10), any attempt at a full description would be out of place here.

The Devonian may be divided into the Lower, Middle, and Upper, and Savage ('20) says that the total thickness of the Devonian rocks in southwestern Illinois is not less than 800 feet. The lowest series of the Devonian is the Helderbergian, represented by Bailey limestone and Backbone limestone. The high bluff facing the Mississippi from Harrison Creek south to Thebes, which one passes in driving from Jonesboro to Reynoldsville along the Cape Girardeau road, may be classed as Helderberg limestone. The Clear Creek chert is a characteristic layer of the Middle Devonian and may be found in two forms: in limestone, as nodules from one inch to two inches in thickness; and as a regular formation constituting the axis of such elevations as Hamburg Hill, Atwood Ridge, Pine Knob, and Dago Hill, extending down through the Jonesboro quadrangle to Tamms. The gravel pit at Tamms is in this formation, and the silicon which is mined at Delta, in Alexander county, is in the Clear Creek chert which has disintegrated. We speak of it because it outcrops in the beds of so many streams, such as Clear Creek, and others, and is an important road-builder and soil-former. Overlying the Clear Creek chert is the Dutch Creek sandstone, so called because it is best 


\section{Plate LXXI}

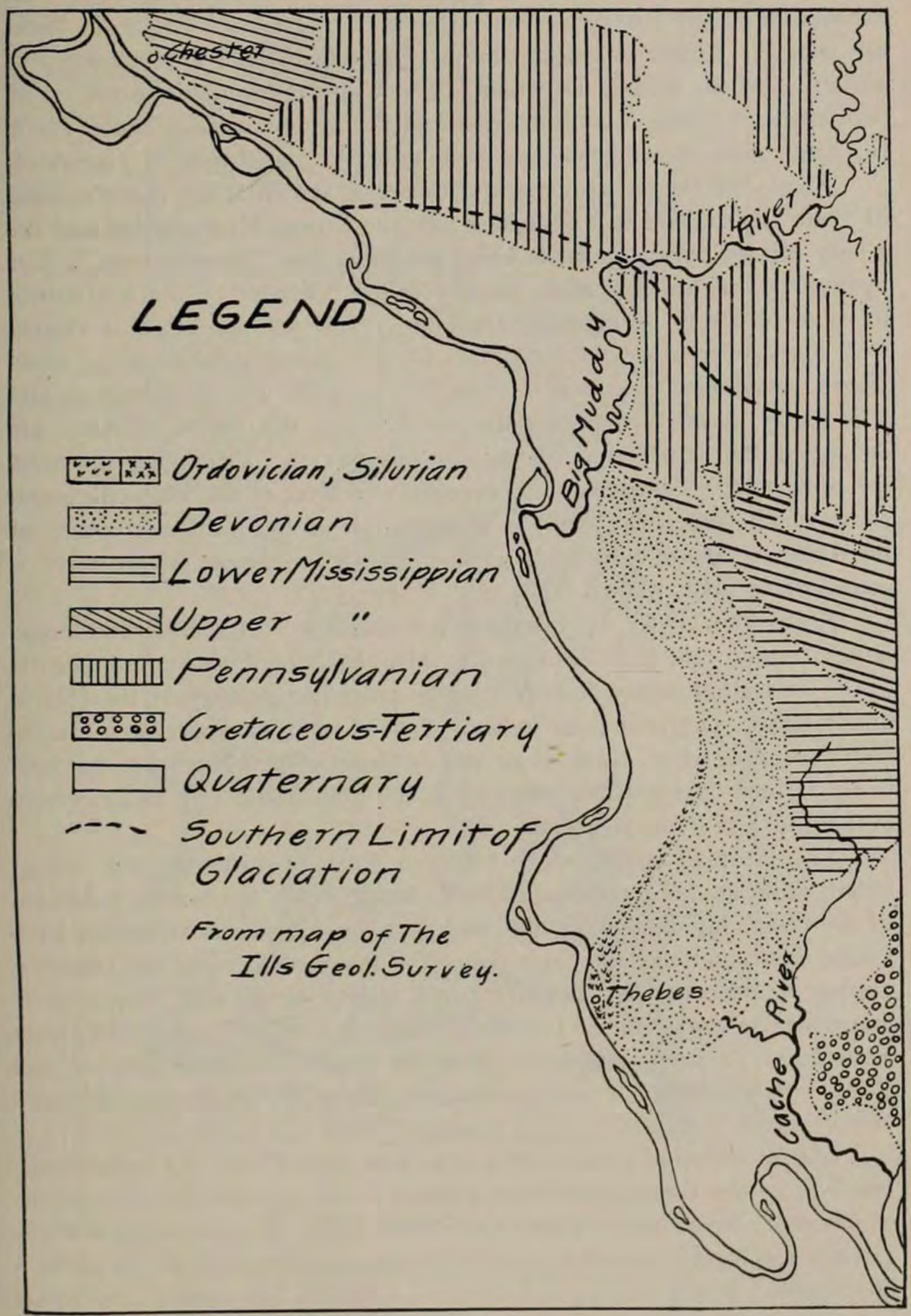


exposed along Dutch Creek, in the southwest corner of Union county. Grand Tower limestone, a layer about 150 feet in thickness, is well exposed in an old quarry a short distance east of Grand Tower, in Jackson county. Lingle limestone and Meisenheimer shale are other representatives of the Middle Devonian. The Upper Devonian is made up of two layers, the Alto Pass formation and the Mountain Glen shale, which is a black shale showing up near Mountain Glen, northwest of Jonesboro.

Above the Devonian is the Mississippian, shown at the extreme right of Plate LXXI, and this is divided into the Lower Mississippian and the Upper Mississippian, the latter being known as the "Chester group." The Springville, or "calico," shale (locally called "ganister",) which is mined in some places to be manufactured into refractory fire-brick, is classed with the Lower Mississippian. The Chester group is made up of limestones, sandstones, and shales, from 700 to 1,200 feet in thickness, and it is partly in this group that the sink-holes in the region of Anna are developed, that entire region being a limestone area. Proceeding upwards, we come to the Pennsylvanian, whose lower layer is the Pottsville sandstone which forms the bluffs at Pomona, all of the northeast corner of the Dongola quadrangle being in fact mostly sandstone where there is considerable poor, gullied land.

Above the Upper Mississippian are the layers of the Carboniferous which contain coal beds developed at Murphysboro, Herrin, and Harrisburg-more thoroughly described in the published geology of the Herrin quadrangle. The coal beds indicate that at intervals there were freshwater marshes which received an accumulation of plant remains, this coal being formed during what is known as the Carbondale and McLeansboro periods of the Pennsylvanian.

The Permian epoch, which followed the Carboniferous, was one of uplift, faulting, and intrusions of lava, during which the eastern extension of the Ozark highlands occurred, and as a consequence of which we have faults, dikes, and volcanic plugs formed in many of the southern counties. During Cretaceous and Tertiary times, clays, sands, and gravels were laid down, as shown in the lower right-hand corner of Plate LXXI, from Fayville to Tamms. After this came the deposit of sands, gravels, and clays, with glaciation of part of the area during the Quaternary or more recent period.

Glacial and wind action.- As can be seen from Plate LXXI, the southern limit of the Illinoian ice sheet extends across the northwestern corner of our area. According to Savage and Shaw ('12), this last advance of the glaciers southwards covered about 1000 square miles south of the parallel 38 degrees. It left no sign of a terminal moraine, but worked over material deposited previously, brought down rocks, such as quartz, from Canada, and filled up and modified former drainage channels. An example of 
Plate LXXII

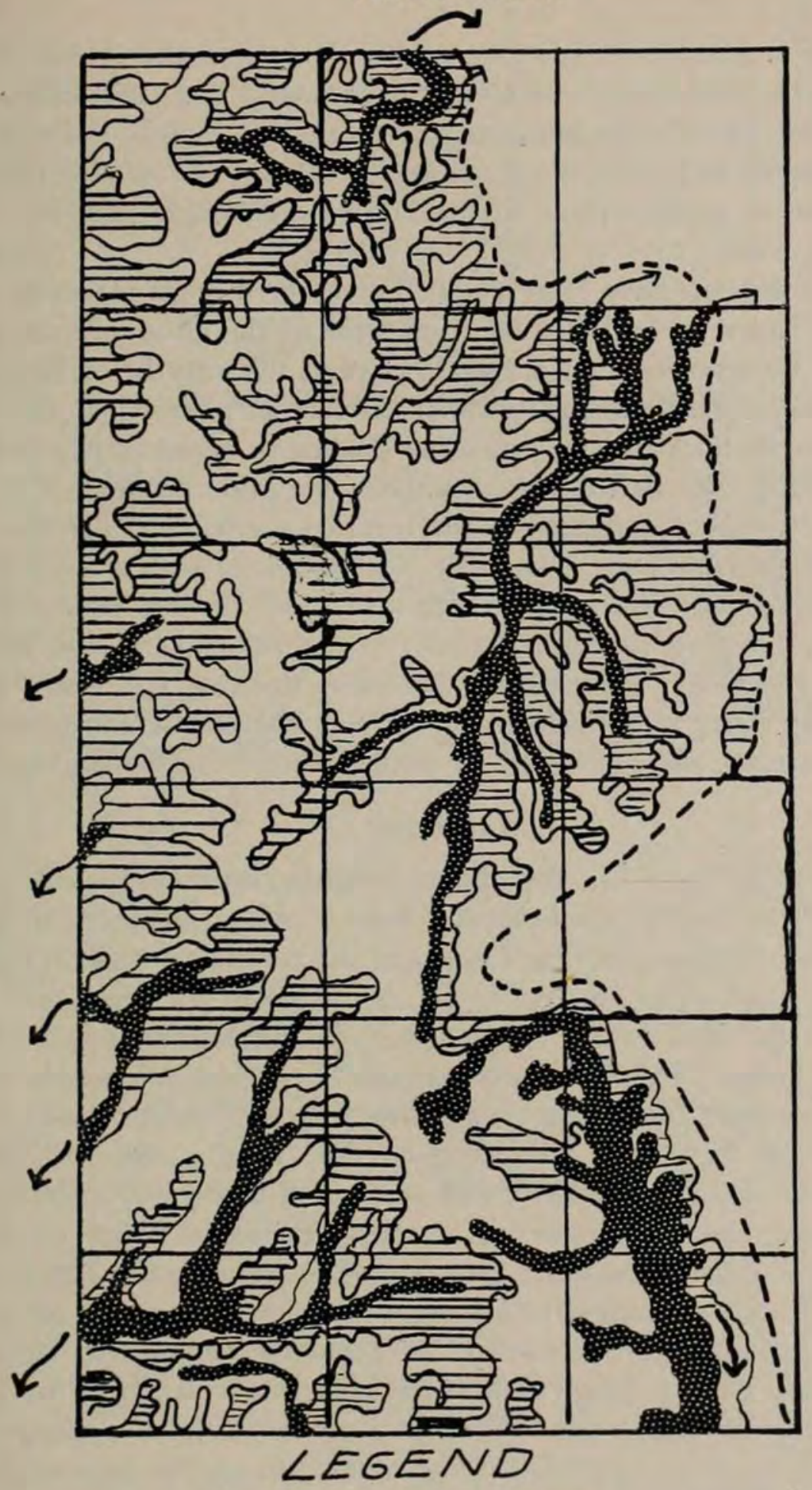

Eyellow Silt Loam

पyellow Graysilt Loam

Mixed Loam

Scale " $"=1$ Mile 
the latter is found in the fact that at one time the outlet of Big Muddy River into the Mississippi was filled up, forming a large lake called "Big Muddy Lake," which was northeast of this region. Glacial striae, having a general north and south direction, are found just east of this region at Bush, while in another place in the Herrin quadrangle they run south 30 degrees west.

Glacial deposits have been modified or covered up in places by loess, which was blown up by the wind from some of the great outwash plains formed by the glaciers. According to Savage, this may be of two kinds, the deep loess, which has a depth of 50 feet in places, and thin loess about 10 feet in thickness, the two often shading so imperceptibly into each other that they may be considered parts of the same deposit. The thick loess may have been deposited in the forested regions and the thin loess in the undrained lowlands. The true loess weathers with a more or less vertical face, gives a test for lime with acids, and contains the remains of land shells. A good example is found in the cut at Dug Hill, between Jonesboro and Ware, along what is known as the Dug Hill road. South of the Cache River in the Dongola quadrangle the loess is not typical but is non-calcareous, and can hardly be distinguished from the silt loams.

\section{SOIL TYPES}

A. Upland soils.-In the upland area the variation in soils is not marked. Prevailing opinion holds that loess is present in almost all of the upland soils in degrees varying from light deposits in the eastern sections covered by this report, increasing to the west, to the true deep loess deposits on the bluffs from Dutch Creek, in the Jonesboro quadrangle, south to Thebes. The true loess contains a considerable percentage of lime, and we have found lime concretions imbedded in the banks of the streams. The loess soils, according to the "county advisers" in this region whom we have consulted, will grow good blue-grass, sweet clover, or red clover, and the presence of certain leguminous plants on top of some of these ridges shows that the soil contains considerable lime; hence is not at all acid, as many of the soils on run-down farms are apt to be.

Two soil types, the yellow silt loam and the yellow-gray silt loam, together comprise over 80 per cent of the upland soils. They differ in the fact that the yellow-gray silt loam is an intermediate phase, approaching the gray silt loam on tight clay, being a mixture of the gray silt loams with the yellow silt.

The three main soil types are shown in Plate LXXII: the mixed loam in the bottoms; the yellow silt loam on the sides of the hills and ravines; and the yellow-gray silt loam on the tops of the ridges. Roughly speaking, the last two types are of about equal area, and are so represented. 


\section{Plate LXXIII}

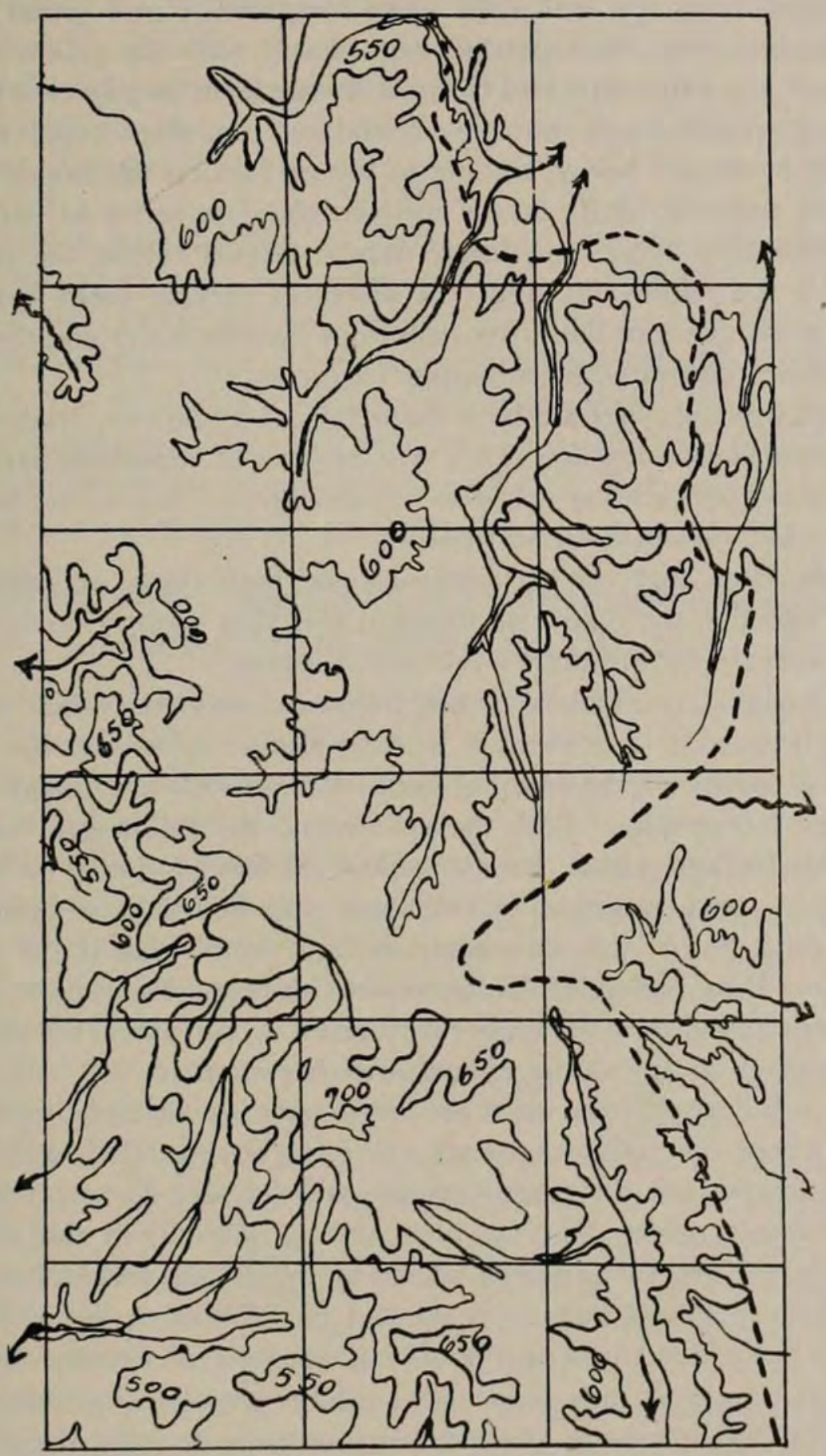

Topography corresponding to the soils shown in Plate LXXII. Contour interval 50 feet. Scale one inch to the mile. 
The soil surveyors cover each section by "forties" and their map agrees very closely with the topography (see Plate LXXIII). Near Alto Pass, when timber maps and soil maps were compared it was found that the present timber areas corresponded very closely with the yellow silt loam type of soil, the ridge tops and bottoms having been largely cleared.

The gray silt loams are also found on the ridge tops, while the yellow silt loams are below, coming to the surface on the slopes. As the topography near the bluffs on the western side is a series of narrow valleys separated by long, exceedingly narrow-topped ridges, the prevailing soil type is the yellow silt loam. At distances varying from four to five miles from the western bluff, the ridge tops become wider and the yellowgray silt loam occurs with increasing frequency.

These two soil types are both characterized by porous, friable surface soils and pervious subsoils. They are capable of absorbing large quantities of water and are very resistant to drought. They do not bake hard when dry, but remain loose and porous.

While rated high as agricultural soils, both types are deficient in nitrogen, although the yellow silt loams of this area seem richer in nitrogen than the average upland-timber yellow silt loams.

The body of continuous timber follows closely the yellow silt loam area, not because of any relation between timber types and the physical or chemical nature of the soil, but because these soils are found over the very rough topography. Both the yellow and the yellow-gray silt loams are suitable for agriculture, but the yellow silt loam is found on the steep slopes which tend to erode if cultivated and hence have been left in timber. As a test of this statement, we have found that if the soil map of the Alto Pass region of Union county showing the yellow silt loam were superimposed over the timber map made by our party, the two would closely coincide so far as the upland area is concerned.

The soils derived from chert are apt to have a poor moisture-retaining capacity where the rock fragments are fairly large. This kind of soil resembles gravel, but the fragments are angular and flinty. The degree of chertiness is reflected in the type of tree growth, in the extremely cherty soils, the general forest of white oak, black oak, and hickory giving way on them to a very inferior post-oak type. The shortleaf pine on the western slopes of the bluffs near Wolf Lake is on a moderately cherty soil.

$B$. Bottomland soils.-As the eroding process is general in the uplands, the flood-plains of the secondary streams draining these uplands are constantly receiving a portion of the wash from the slopes, strips of sedimentary deposits being thus formed. With the exception of the valleys of the Big Muddy and Cache rivers, these strips are very narrow. In general such soils are mixed loams (see Plate LXXII), and since they 
lend themselves readily to cropping after drainage, almost every acre of them has been cleared. An exception, however, is the gray silt loam on tight clay along the Big Muddy River. This does not drain well and may be classed as an absolute forest soil. Among the other bottomland-soil types are the yellow fine sandy loam, the brown sandy loam, brown silt loam, and drab clay loam. Cypress swamps seem to predominate on this last variety of soil.

\section{Climate}

At Chester, on the upper boundary of our area, the annual rainfall is 45.18 inches and at Anna the mean temperature is 57.3 degrees $\mathrm{F}$. The mildness of the climate at Anna can be judged by the fact that Magnolia grandiflora flourishes as a street tree. At Cairo, just beyond the lower boundary of the region, the mean annual temperature is 58 degrees $F$, and the annual rainfall 41.6 inches. From this it can be seen that both rainfall and temperature are favorable to tree growth; and only rarely is there a total loss of fruit due to spring frosts.

\section{Milling and Logging Operations and Wood-using Industries in Southern Illinois}

The sawmills of this region, portable and stationary, range in their daily cut from 2,000 to 20,000 feet. According to Seerey ('18), the smaller cut mentioned would rank a mill as belonging to Class A and the larger cut would indicate a Class B mill.

Portable mills are usually equipped with rack and pinion or cable drive and friction or belt feed or a combined belt and friction feed, though many in this region are run with a traction engine. A 25 horse-power engine, if properly handled, will keep a circular saw working to capacity and at the same time will run a small planer and edger. The owner usually has a circular saw, ranging in diameter from 54 inches upwards, with solid or inserted teeth. According to experts the diameter of the saw should be approximately one and one-half times the diameter of the largest $\log$ to be cut, that is, a 36 -inch $\log$ needs a 54 -inch saw and a 40 -inch $\log$ a 60 -inch saw. For very large logs in large mills a double circular saw must be used, that is, a smaller saw above the larger one, revolving in the opposite direction, commonly called a top-saw, so that the sawdust from the top-saw will not be thrown into the lower one, otherwise, in cutting large logs, the saw will not cut through the top of the log and the slab must be removed by means of an axe, resulting in much loss of time.

According to Seerey the life of a portable mill may be placed at 2 to 15 years, the maximum time it is operated each year being about 150 days.

The amount of lumber secured from a $\log$ depends upon several things-such as the condition of the saw and machinery, the defects in the 
$\log$, and, especially, upon the skill of the sawyer in getting the possible maximum of high-grade lumber out of every $\log$, that is, reducing the slabs and edging to the lowest possible figure. An experienced sawyer can "size up" a $\log$ before it comes on the carriage, and will know how to turn and handle it so as to get the most desirable and best-sized pieces out of it. One method is to saw the log "alive" or through and through, edging up the boards afterwards with the circular saw. Still another plan is to slab off the boards on four sides of the log, leaving the "wane," or bark, on each board and then cutting up the squared timber into planks or boards. The "waney" boards are then sent to the edger, which removes the bark, or, some small mills may ship them, since mills are not always equipped with an edger. The slabs may be cut into fire-wood with a cut-off saw or used as fuel for the engine.

Logging operations and costs.-With this digression into mills and machinery, we may next describe a specific logging and milling operation which we took a little time to follow in detail. It was conducted at Ava, Illinois, by the Old Ben Coal Company. The timber being handled was located about $4 \frac{1}{2} 2$ miles southwest of Ava, in Kinkaid township, Jackson county. The mill was in the S. E. corner of Section 32, T. 7 S., R. 4 W., and the cutting area included parts of sections 32 , T. 7 S., R. 4 W., and Section 5, T. 8 S., R. $4 \mathrm{~W}$. Land and timber had been purchased by the company and after cutting the timber the land was to be sold for farming or pasture purposes, at a price around $\$ 15.00$ an acre.

The ordinary operations connected with logging consist of felling, bucking, and loading the logs on drays or log-wagons for transportation to the mill. Skidding, which means hauling the logs for short distances to piles or skidways in the woods by means of horses or other power, was eliminated in this instance as the logs were hauled directly to the mill, about a mile distant, on log-wagons or drays.

The felling crews consisted of two men each, and for felling the trees and cutting them into log lengths they received $\$ 3.50$ per M. feet, the minimum top-diameter of logs being 12 inches, Doyle-Scribner scale. According to Seerey, two men working in timber which will run from 8 to 10 logs per 1,000 feet will ordinarily cut between 5,000 and 6,000 feet per day, the logs varying in length from 12 to 16 feet. In Illinois men could not do so well, but two men should cut 4,000 feet per day. Wages in this region have to be graded by what men can receive in the mines, so that good inducements must be offered woods workers, especially in the summer. Teamsters with their teams received about $\$ 8.00$ per M. feet for hauling logs to the mill and did their own yarding, swamping, and road-building.

The mill was above the average in efficiency and cut about 4,000 feet per day, this lumber being hauled to Ava, a distance of $4 \frac{1}{2}$ miles, at a 
probable cost of $\$ 7.00$ per thousand feet The lumber was well manufactured and there was very little waste, since almost everything could be utilized either for riprap lumber for the mines, or for cap-pieces, made out of the slabs. Six men were employed around this mill and wages ran from $\$ 3.00$ to $\$ 5.00$ per day. To run such a mill there would be required a sawyer, an engineer, a setter, one slab sawyer, an off-bearer, and a man to take away sawdust. After the logs had been taken out of the trees, other crews went in to make ties and mine props out of the tops, for which they were paid by the piece. It is the custom in some places to go through and take out the young white oak trees for legs and cross-bars, as it is claimed that such trees will be badly damaged by felling the large timber. All species were being cut in this operation and the average tree would yield not far from 100 board feet. We are indebted to Mr. Charles W. Weaver, superintendent of operations, for the many courtesies extended to us-following the felling crews and making stem analyses of trees, getting information about prices, etc., etc.

Log rule.-The official rule for scaling logs in the state of Illinois is the Doyle-Scribner rule, which Chapman calls a hybrid or combination $\log$-rule. The straight Doyle rule is based upon a rule of thumb which is supposed to make certain deductions for saw kerf and slabbing of the log, and reads: "Deduct 4 inches from the diameter of the log at the small end as an allowance for slab. Square one-quarter of the remainder and multiply by the length of the $\log$ in feet." For logs 16 feet in length this resolves itself into deducting 4 inches from the diameter at the small end and squaring the remainder, this giving the contents by the Doyle rule. For example, a 16-foot $\log 12$ inches at the top end inside the bark would have a content of 64 board feet. This makes it very easy to apply as a rule of thumb, but for small diameters it gives very low results as compared with some other log rules-about half as much as the Vermont rule for an 8-inch iog, the Doyle giving only 16 board feet where the Vermont gives 40 board feet. For large logs the Doyle rule gave large results, so for $\operatorname{logs} 28$ inches and over the Scribner rule values were taken and the combined rule was known as the Doyle-Scribner. The Forest Products Laboratory, Madison, Wisconsin, in commenting upon various log rules after an exhaustive study, says: "A combined Doyle-Scribner rule, using Doyle on logs up to 28 inches in diameter and Scribner for logs 28 inches and over gives the largest possible overrun for both large and small logs." The term "overrun" means the amount by which the mill tally of lumber sawed exceeds the scaled contents of the logs on the log deck or in the woods. So far as we have investigated the subject in this region the overrun given by the Doyle-Scribner rule is from $20 \%$ to $25 \%$, varying of course with the size and soundness of the logs and the degree of utilization practiced by the operator or in the region. 
List of Mills, with Location and Output

\begin{tabular}{|c|c|c|c|c|}
\hline $\begin{array}{c}\text { Name and address of operator } \\
\text { or manager }\end{array}$ & Location of mill or plant & Type & Condition & $\begin{array}{c}\text { Daily or yearly } \\
\text { capacity } \\
\text { board feet }\end{array}$ \\
\hline 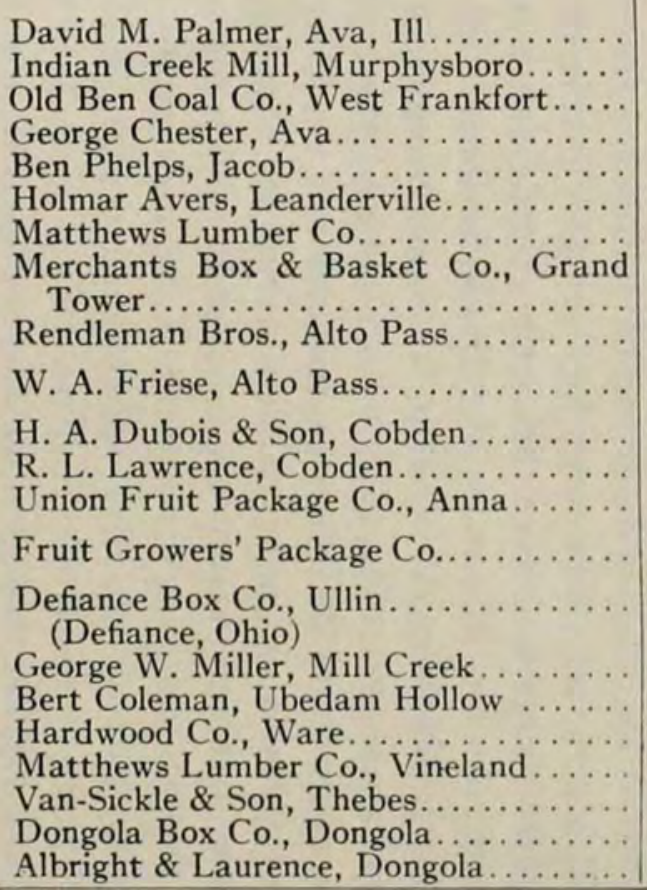 & 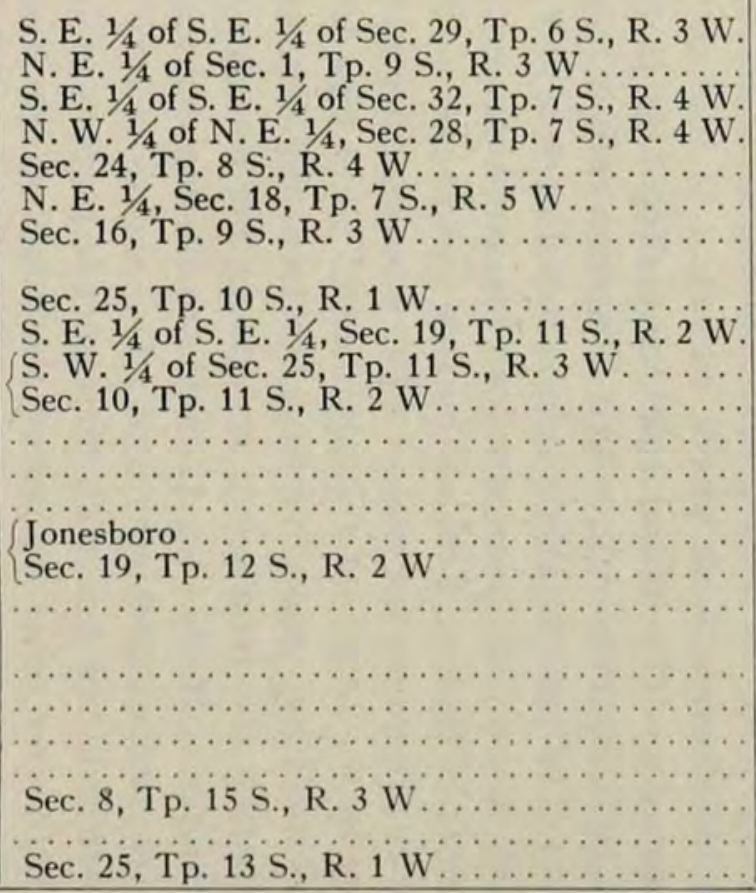 & $\begin{array}{l}\text { Portable. } \\
\text { Stationary } \\
\text { Portable.. } \\
\text { Portable. } \\
\text { Portable. } \\
\text { Portable. } \\
\text { Stationary } \\
\text { Stationary } \\
\text { Stationary } \\
\text { Portable.. } \\
\text { Stationary } \\
\text { Stationary } \\
\text { Stationary } \\
\text { Stationary } \\
\text { Stationary } \\
\text { Portable... } \\
\text { Stationary } \\
\text { Stationary } \\
\text { Portable.. } \\
\text { Stationary } \\
\text { Stationary } \\
\text { Stationary } \\
\text { Stationary } \\
\text { Portable.. }\end{array}$ & $\begin{array}{l}\text { Running.. } \\
\text { Running.. } \\
\text { Running.. } \\
\text { Running.. } \\
\text { Running.. } \\
\text { Idle...... } \\
\text { Idle...... } \\
\text { Idle...... } \\
\text { Running.. } \\
\text { Running.. } \\
\text { Idle...... } \\
\text { Running.. } \\
\text { Running.. } \\
\text { Running.. } \\
\text { Running.. } \\
\text { Running.. } \\
\text { Running.. } \\
\text { Running.. } \\
\text { Running.. } \\
\text { Running.. } \\
\text { Running.. } \\
\text { Running.. } \\
\text { Running.. } \\
\text { Running.. }\end{array}$ & $\begin{array}{l}2,000 \text { (daily) } \\
7,000 \text { (daily) } \\
4,000 \text { (daily) } \\
2,000 \text { (daily) } \\
2,000 \text { (daily) } \\
2,000 \text { (daily) } \\
\text { 2,000 (daily) } \\
12-14 \text { M. (daily) } \\
100 \mathrm{M} \text {. (yearly) } \\
2,000 \text { (daily) } \\
20 \mathrm{M} \text {. (daily) } \\
150 \mathrm{M} \text {. (yearly) } \\
150 \mathrm{M} \text {. (yearly) } \\
100 \mathrm{M} \text {. (yearly) } \\
200 \mathrm{M} \text {. (yearly) } \\
2,000 \mathrm{M} \text {. (daily) } \\
100 \mathrm{M} \text {. (yearly) } \\
\text { 2,000 M. (daily) } \\
\text { 2,000 M. (daily) } \\
5,000 \mathrm{M} \text {. (daily) } \\
5,000 \mathrm{M} \text {. (daily) } \\
5,000 \mathrm{M} \text {. (daily } \\
3,000 \mathrm{M} \text {. (daily) } \\
\text { 2,000 M. (daily) }\end{array}$ \\
\hline
\end{tabular}




\section{The Veneer Industry}

The term veneer covers thin strips or slices of wood used in the manufacture of crates, hampers, berry boxes, and baskets. The center of manufacture for this region may be said to be at Anna, Jonesboro, Cobden, Alto Pass, and Dongola. There are three kinds of veneer: sawed, sliced, and rotary cut, and most of the veneer manufactured in this region may be said to be of the last variety. The main logs going into this trade are socalled "softwoods," such as elm, sycamore, red and black gums, maple, cottonwood, and tulip-tree, which come from bottomlands that are being cleared for farming. Logs may be hauled in to the mills by dray or motor truck, shipped in on railroad cars, or rafted down the Ohio and Mississippi rivers. Very large logs are preferred for veneers, but they can be used down to 12 inches, or even less at the small end.

In making sliced or rotary cut veneers from the $\log$, it is first cut into bolts of certain lengths depending upon the length of the lathes upon which they are turned out, some running up to 76 inches; but usually the bolts are shorter. They are then steamed for 12 to 24 hours, to soften the wood, after which they are spanned in a machine resembling a lathe and turned past the edge of a large stationary knife which may take off a continual roll like a thin piece of paper, or short pieces such as go into the sides of hampers. There may be considerable waste in this process, due to twisted grain, splits, frost cracks, seams, knots, and other defects in the logs, but with a clear sound $\log$, the number of superficial feet of veneer secured is considerable. Rough waste may be used to fire the boilers, and the six- or eight-inch cores which are left at the center of the bolts may be used for the bottoms of berry boxes or sold to some pulp company for pulp-wood. Some of the processes in connection with the manufacture of different classes of veneered packages may now be considered in greater detail.

Bushel baskets for shipping fruit.-At present the main wood used for this purpose is black gum, as it makes a good-looking white basket. For the top hoop of the basket, oak was formerly used, but now good hoops are made from black gum and pecan, soaked before being bent. To make these hoops, which give strength to the top of the basket and over which the cover fits, logs are sent into the mill in lengths of five feet two inches. They are split into boards $7 / 8$ of an inch thick with a band-saw, having a kerf of $1 / 16$ of an inch, so that there is very little waste. These boards, after slabbing, are run through a machine with a series of small circular saws, like a lath-machine, which splits the boards into strips of a suitable thickness for bending. The main part of the basket, called the "web," is made by hand by laying strips on a circular form and joining 
them at the center. These "webs" are then sent to an automatic machine which turns out about five baskets per minute. Wire handles are also put on automatically from wire in rolls and the basket is ready for the cover. Baskets are dried outside on an open porch and the loss in drying is very small.

Hampers.-In the case of hampers which are used for shipping vegetables such as sweet potatoes, the staves are of veneering, each stave 24 inches long. The bottom is made of two half-circular boards joined together with a staple, "cores" left by the circular veneer machines, being used for this purpose. Hampers are made on automatic machines, the staves being fed into the machine with the two narrow flexible strips which, after being stapled, will hold them all together. Good operators when speeding up with these automatic stapling machines, can turn out 150 hampers per hour. Another form of package turned out by the mills and in large demand for shipping peaches and tomatoes is the popular four-basket crate, the baskets nesting in a box made from strips of veneering; and some mills turn out small baskets used for shipping cantaloupes and cucumbers.

\section{MANUFACTURERS IN THE REGION, AND PRODUCTS}

Among the manufacturers whom some of the members of our survey party have visited we may mention the following:

Merchant's Box and Basket Co., Grand Tower, Illinois. Their mill is located on the Mississippi River and gets $90 \%$ of its raw material from Arkansas, Mississippi, Louisiana, Kentucky, and Tennessee. It uses from three to four million feet yearly and employs from 100 to 125 hands, using daily about 12,000 to 15,000 board feet. It manufactures berry crates, grape baskets, bushel hampers, and half-bushel hand-baskets. The woods used are mainly red gum, sycamore, tulip-tree, and tupelo, but a very little beech is used. Logs from 16 inches in diameter and upwards are preferred, and the mill can handle a bolt as long as 76 inches. According to their statement there is very little prime veneer-timber left in Illinois, the best tract, near Reynoldsville, having been cut some years ago.

Rendleman Brothers, Alto Pass. This firm has a mill in the southeast corner of Section 19, Tp. 11 S., R. 2 W., which has been running for six years. It is located near the source of supply, and is equipped with a planer and a veneer machine. It employs six hands, uses annually about 100,000 board feet, and the product is hauled to Alto Pass or Cobden.

W. A. Friese, Alto Pass. Mr. Friese has two mills, one located on Clear Creek in Section 25, T. 11 S., R. 3 W., and another in Alto Pass. The town mill uses about 20,000 board feet annually in supplying part of the local trade with baskets, while the mill out of town saws lumber and railway ties. 
H. A. DuBois \& Son, Cobden. This firm specializes in fruit baskets and hampers, using about 150,000 board feet annually. The foregoing description of processes of making baskets and hampers (pp. 331, 332) was obtained on a visit to their mill.

R. L. Lawrence, Cobden. This manufacturer buys most of his logs in the state, and ships his products to eight states. He uses about 150,000 feet annually and turns out barrels, fruit crates, and fruit baskets. Staves for slack barrels can be made by the veneer process, but the price of barrels has advanced so much in this region within the last few years that it almost prohibits their use, so that smaller packages, like baskets and hampers, are being used.

The Union Fruit Package Co., Anna. Mr. John C. DeWitt is the manager of this company, which is organized on a co-operative basis to furnish growers with strawberry boxes, four-basket crates, and other containers for fruits and vegetables. It uses about 100,000 board feet annually, the logs being purchased locally.

Fruit Growers' Package Company. This company has a mill at Jonesboro, and another located in the woods near Ware, not far from the toll-gate. They are among the largest manufacturers, in this region, of four-basket crates for peaches and tomatoes, melon crates, and many other kinds of packages for local and outside trade. Much of the material is cut during the winter months, and stored and allowed to season for assembling in the summer.

Two other box concerns were found in this region, the Defiance Box Company, located at Ullin, with main office at Defiance, Ohio, making crockery crates; and the Dongola Box Company, at Dongola.

\section{NECESSITY FOR A LOCAL SUPPLY OF "SOFTWOODS" FOR VENEER PURPOSES}

Since southern Illinois is a fruit and vegetable country, we believe it to be very essential to the prosperity of its business that there should be a local supply of bottomland timber, such as elm, sycamore, cottonwood, and gum, for the making of packages for shipping fruit and vegetables. This is a point which we believe companies adding to their acreage of orchards are not appreciating as they should. Some of the local mills see only a five years' supply of local logs ahead of them, which means that when supplies of this kind have to be shipped from more distant points, the grower will have to pay more for them and this increase will have to be charged up to the consumer.

Col. Greeley cites the fact that the supply of lumber for boxes is getting to be a very serious matter with the citrus growers in Florida. They use 12,000 boxes yearly, each requiring about $5 \mathrm{r} / 2$ feet of lumber, while the shippers of truck-produce require about $13,000,000$ additional. 
The rapid exhaustion of southern pine may in a few years greatly hamper the expansion of the citrus industry.

The fact that southern Illinois faces a similar situation should, we believe, lead men who do not need wet bottomland tracts for farming to save these woods, since their growth is rapid and there should always be a good market for the faster growing varieties in the form of logs for veneer.

\section{Charcoal-Making \\ PROCESSES AND YIELDS}

Mr. J. E. Black, Ullin, Illinois, has a battery of six brick kilns, each with a capacity of about 60 cords, and about one mile southeast of Olive Branch, on the Illinois Central Railway, there is a battery of four kilns. Cordwood which comes from bottomlands in which the cypress has been cut out, costs about $\$ 3.00$ per cord, delivered at the plant, and the charcoal product from it is sold to companies making gunpowder. Almost any species of hardwood can be made into charcoal, but we are informed that to make the right kind of charcoal for blasting powder a mixture of the coals resulting from carbonizing different species must be made. As a rule the denser the wood the heavier the coal, charcoal made from cottonwood being about half as heavy as that from ash. For this reason, the lighter woods, such as willow and cottonwood, are better adapted to sporting powders.

The wood is cut into cordwood lengths and in the best practice is allowed to season for a year, either in the woods or at the plant. The main reason for this is that the higher water-content of the green wood necessitates more fuel for carbonization. Palmer ('14) says that hardwood is distilled in three forms of apparatus: $(a)$ in brick kilns, $(b)$ in retorts, and $(c)$ in ovens. The retort is the modern form of apparatus because the valuable vapors are saved and condensed to make wood alcohol and acetate of lime, and because the wood is drawn into them on steel cars, and less work is required for charging and recharging than with brick kilns. The kiln type is only economical when the chief product desired is charcoal, for which a fair price can be obtained, and in locations where wood is fairly cheap and plentiful.

The brick kiln has a circular base, the entire structure resembling a beehive in form. After it has been filled with wood it is lit at the top and closed up except for outlet holes near the base which can be opened or closed with brick or fire clay to increase or decrease the draft. The time required for finishing a kiln depends somewhat upon weather conditions, but it is usually from 12 to 22 days, including the charging of the kiln, the cooling, and the discharging. The yield (Geer '07) per cord of wood from the brick kiln is from 45 to 52 bushels of charcoal, and prices 
may vary from seven to ten cents per pound, depending upon market conditions. The fact that with oven retorts the charcoal is more or less of a by-product makes it very hard for operators of brick kilns to compete in the open market with the prices made by operators of retorts and ovens, since the latter can make a profit on other valuable products, such as wood alcohol and acetate of lime, and powder companies will not maintain kilns of their own when they can buy their charcoal in the open market for less than the cost of production.

\section{Ties and Mine Timbers \\ RAILROAD CROSS-TIES}

While tie-treating plants in the state are getting a very large majority of their ties from neighboring states to the south of us, Arkansas, Missouri, Tennessee, and Kentucky, the number of cross-ties actually produced in Illinois is by no means insignificant. Reports from ten railroad companies show that in 1921 , ties to the number of 913,940 were produced in Illinois and landed along their rights-of-way. Making an allowance for two roads out of this number which did not purchase their normal number in 1921 , we can safely say that one million ties is the normal output of the whole state of Illinois, and of this number from 300,000 to 500,000 would be produced in sonthern Illinois, the majority of these coming from the region covered by the forest survey party this past summer. Assuming that it takes 32 ties of good size to make 1,000 board feet of lumber, there would be $32,000,000$ board feet of timber required for this purpose every year in Illinois.

\section{Specifications, Grades and Sizes, Species}

According to the specifications of one of the leading railway companies purchasing ties in Illinois, "All ties shall be free from any defects that will impair their strength or durability as cross-ties, such as decay, splits, shakes, or large knots, and should be made from trees which have been felled not longer than one month. All ties shall be straight, well manufactured, cut square at the ends, bottom and top parallel, and have the bark entirely removed. All ties shall be 8 feet, or 8 feet 6 inches long."

Ties according to size are graded as follows:

TABLE 8

\begin{tabular}{|c|c|c|}
\hline Grade & $\begin{array}{c}\text { Sawed or hewn top, bottom, } \\
\text { and sides }\end{array}$ & Sawed or hewn top and bottom \\
\hline $\begin{array}{l}1 \\
2\end{array}$ & $\begin{array}{l}\text { None accepted } \\
6^{\prime \prime} \text { thick } \times 7^{\prime \prime} \text { wide on top }\end{array}$ & $\begin{array}{l}6^{\prime \prime} \text { thick } \times 6^{\prime \prime} \text { wide on top } \\
6^{\prime \prime} \text { thick } \times 7^{\prime \prime} \text { wide on top }\end{array}$ \\
\hline 3 & $6^{\prime \prime}$ thick $\times 8^{\prime \prime}$ wide on top & 7" thick $\times 7$ "' wide on top \\
\hline $\begin{array}{l}4 \\
5\end{array}$ & $7^{\prime \prime}$ thick $\times 8^{\prime \prime}$ wide on top & $7^{\prime \prime}$ thick $\times 8^{\prime \prime}$, wide on top \\
\hline
\end{tabular}


On the basis of the durability of the different woods, the same railway company divides them into two classes, ties which need to be treated and those which do not, with subclasses under each of these based on relative natural durability of the wood, as follows:

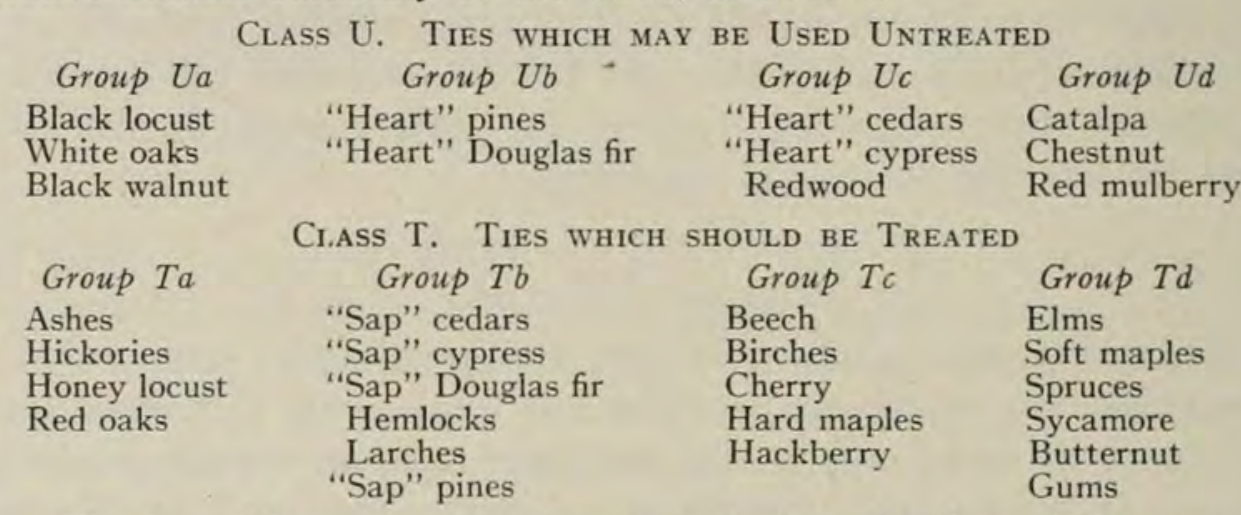

The board-foot contents of a cross-tie eight feet long (Chapman '21) may be found by looking up the log scale for a log of that length and diameter inside the bark, just as if the log were being scaled. Or the cubic-foot contents of the tie may be calculated from the basal areas of the top and bottom, converting this into board feet by the use of a converting factor. For ordinary purposes we may consider that a cubic foot is equivalent to 5.5 board feet, since in sawing a log quite a large amount is lost in edgings and sawdust. Mill men estimate that a tie eight feet long with a 6 -inch by 8 -inch face (a No. 3 tie) scales about 32 board feet and that 30 of such ties will make 1000 board feet of lumber. Ties which are $81 / 2$ feet long and have a 7 by 9 -inch face (No. 5 tie) contain from 40 to 44 board feet each, or we may say that it takes from 23 to 25 of them to make a thousand board feet of lumber. Switch ties are cut about twice the length of ordinary ties and consequently with this greater length would have a still greater content.

Out of a total of 280,077 railroad ties purchased by one road in Illinois in 1921, we find that 155,940 came in class $\mathrm{T} a$, comprising such species as the ashes, hickories, honey locust, and red oaks. This shows that over half of the ties came from species that were not durable by nature, but were used because of the growing scarcity and high price of white oak and other durable species. It also shows the increasing value of many of our bottomland species which have until very recently been considered of little value for ties. The reason for this will be discussed later under the head of wood preservation.

In the summer of 1919 prices received for ties as well as the price for making them, reached their peak, the former varying near Jonesboro from $\$ 1$ to $\$ 1.90$, the higher price being received for a No. 5 tie ( 7 by 9-inch face) of such species as hackberry and soft maple, delivered at the 
railroad. The prices paid for hewing ties varied from 30 cents for No. 1 up to 50 cents for No. 5, and about 25 cents each was paid for hauling them a distance of six miles. During the summer of 1921 prices had fallen considerably for both ties and labor, so that the best ties brought about $\$ 1$ delivered, and the cost of hewing was from 15 to 25 cents each.

Ties are produced in this region chiefly in three ways: (1) by small portable mills, sawing a large proportion of beech, (2) by farmers who get out ties during the winter or other slack periods, and (3) by professional "tie hackers" who generally work in pairs, maintaining a small temporary camp financed by the operator who has the contract. Where coal companies are clearing off timberland it is the custom to send in men after the logging to work up the tops of trees into railroad and mine ties, effecting in this way a rather close utilization of the tree contents.

\section{Wood Preservation and Tie-treating Plants in Illinois}

The increasing prevalence of preservative treatment in Illinois will vitally affect the future timber supply and forest management. Any process by which the durability of a species can be doubled or trebled will lessen to just that extent the drain upon our forests; and instead of taking a longer time to grow white oak, for example, attention may be given to cottonwood, soft maple, willow, sycamore, gum, and other fast-growing bottomland timber, on short rotations. According to C. P. Winslow, Director of the Forest Products Laboratory at Madison, Wisconsin, foresters are prone to emphasize the great loss in the forest through forest fires and say little about the amount of material saved to the country by preservative treatment. This is a phase of conservation which therefore deserves some consideration.

A complete list of the tie-treating plants in Illinois, several of which we have visited, is as follows:

American Creosoting Company, Marion

Ayer \& Lord Tie Company.... Carbondale

Joyce-Watkins Creosoting Co...Metropolis

Indiana Tie Company....... Joppa (Main office at Evansville, Ind.)

Kettle River Company...........Madison

T. J. Moss Tie Company.......Mt. Vernon and East St. Louis

C. B. \& Q. Treating Plant..... Galesburg

Midland Creosoting Co........ Granite City

We have visited personally the plants at Marion, Carbondale, Mt. Vernon, Metropolis, and Galesburg, to get some information about processes and number of ties and amounts of other timber treated annually. In general these plants may be divided into two classes, those which preserve ties for their own railroad lines, as those of the C. B. \& Q., and 
those which do commercial treating for several railroa's or for private companies. With the exception of the plants at Gaiesburg and Madison, these plants receive ties from the region now under discussion.

The railroad companies have taken the lead in timber preservation because of the increasing scarcity and high prices of railway ties, this being one class of material for which no satisfactory substitute has been invented. They have found that many species of timber not sufficiently durable for cross-ties may be made so by preservative treatment. Many of them have been creosoting timber long enough to obtain reliable data from experimental tracks laid with ties treated by various methods, upon which exact observations have been made through extended periods under all classes of climate and soil conditions.

A number of the large steam roads, for example, the Burlington in Illinois, have extensive treating plants fitted to handle large quantities of timber in an efficient manner. Starting in with cross-ties, many have found out that it effects a great saving to treat every stick of timber used for trestles, piling, bridge-stringers, and telephone poles. They have found out that all species need air-seasoning for a considerable length of time and some of them keep as much as six million feet of material in their yards for a year-which means carrying a heavy investment. The idea seems to be growing that all species are benefited by preservative treatment and that all can be treated successfully and advantageously.

Nearly all cross-ties are treated by the closed tank or "pressure process," in which the wood is subjected to treatment under pressure designed to secure a heavy absorption of the preservative. There may be as many as eight of these treating cylinders at one plant, each about 125 feet long and from five to six feet in diameter, with heavy air-tight doors which can be locked while the cylinder is being subjected to an initial vacuum or to pressure. Each cylinder will hold about 16 steel cars or "cylinder buggies," which after being loaded with 52 eight-foot ties, are drawn into the cylinders by means of cables or small donkey engines, each filling by these cars being known as a "charge." The displacement of one of these cylinders is about 3,900 cubic feet.

Preservatives used.-The principal preservatives in use at the present time are creosote oil, zinc chloride, and an emulsion of zinc chloride and creosote, treatment with the last being known as the "Card process" from its inventor. Modifications of the method known as the "pressure process" have been devised to bring about preservation without taking too much of the liquid. One of these, known as the Rueping process, is used with creosote at the plants at Metropolis and elsewhere. Since its design is to leave the creosote only in the cell walls and not in the pores of the wood cells, it is sometimes called the "empty cell" process. 
Creosote has the advantage that being more or less oily, it does not wash out of the wood readily, so that it is adapted to ties in wet places. Zinc chloride, while classed as a soluble salt, has given good satisfaction and is applied with pressure in the same manner as creosote, the process being known as "Burnettizing." We were shown a red oak tie at the Mt. Vernon plant which had been treated with zinc chloride in 1899 and the wood was still sound and heavy, the main failure being where it had been cut by the tie plates. This showed a durability of 22 years, whereas red oak untreated is rated at about eight or nine years only. This would seem to belie the statement that zinc chloride is unsatisfactory because of its solubility in water. There has been complaint that it interferes with the automatic signals by its effect on the electric current.

Results of treatment and effect on different species.-Mr. J. H. Waterman, Superintendent of the Galesburg plant, rates the value of the different processes in the following order: first, straight creosote; second, the Card process; and third, Burnettizing (zinc chloride). According to his experience the average life of an untreated tie is not over four years, but over twelve years' life are got out of some of their treated ties, with the possible exception of chestnut. He believes that much depends on the thoroughness of the treatment and the time of the year when the timber is cut. Thorough air-seasoning is recommended for every stick of timber treated.

His observations upon the ordinarily less durable species are of value in this discussion. He states that cottonwood if properly treated with creosote will give as long life as any tie he handles. Beech, birch, and maple will only give about four years' service without treatment, but make good ties when properly treated. As to hard maple, his road has in Nebraska a number of these treated ties in the track and he believes that they will get twenty years of life out of 90 per cent of them because they were cut in the winter months; and the same can be said of birch, soft maple, and beech if properly handled. The latter is a species which has been brought into the market within the last few years, altogether because of the use of preservatives. Mr. Waterman further believes that durability of ties will be doubled by the use of heavy rails and tie plates, since the failure of many softwood ties is due to cutting rather than to decay.

Ordinary pressure process.-Leaving out the Rueping process, the ordinary pressure process with zinc chloride or creosote is to put the trams carrying ties or other material into the retort and draw an initial vacuum of about 25 inches for one hour, more or less according to the specifications of different railroads. The creosote is then introduced under sufficient pressure to drive the preservative into the pores of the wood, the length of time for absorption depending upon the species of wood and, 
again, upon the specifications under which the contractors are working, but varying from two to three hours. The pressure is then removed, the preservative is withdrawn to the storage tanks, and the material is allowed to drip for some time before being returned on the trams into the yards. The amount of preservative is usually specified at so many pounds per cubic foot, a "full cell treatment" requiring 12 pounds per cubic foot of wood. Owing to the large amount of material kept on hand for seasoning and the space needed for storing, receiving, and dispatching it, these timber-treating plants are usually located at some distance from towns and adjacent to railway lines, with a large tract of land for buildings, spurs, and yards.

Some of these plants have been equipped for treating wood-block paving, the blocks being made at the plant from southern pines, and the process being similar to that for treating railway ties, except that the blocks are put in containers with perforated sides instead of being loaded upon trams. The plant at Granite City specializes on paving blocks and piling, and does not treat over 3,000 ties a year. It uses the Rueping process entirely.

\section{TIMBER USED IN COAL MINES}

Of the four counties coming within the scope of this report, only Jackson county mines any coal. It is credited with an output of $1,204,949$ tons for the year ending July 30, 1921. The timber supply of the other three counties, however, is very important as furnishing a supply of mine timbers to adjoining counties - to Williamson, which mined 10,822,566 tons, and to Franklin, which produced during 1921 12,723,700 tons, exceeding the amount produced by any other county in the state. High freight rates, of course, have their effect upon the distance to which mine timbers are shipped, but in general we may say that the coal-mining counties have naturally preferred to save some of their own timber and buy from outside sources.

Kind and description of timber used in coal mines.-The main kinds of timber used in coal mines may be listed as follows:

1. Cross-bars or legs. These must be made of white or bur oak. They vary from 10 to 16 feet in length, and must be not less than seven inches at the top end, inside the bark. Thrifty young white oaks are often cut for bars when by leaving them for a few years they might grow into trees of tie size.

2. Mine props. Mine props may be in the round, or split from large trees, and are from 5.5 to 10 feet in length and not less than four inches at the top end. They are classed as mixed oak, which brings the best prices, and miscellaneous, which includes almost any of the bottomland species except willow and cottonwood. 
3. Mine ties. These are of two kinds-room ties and motor ties. The former are of smaller size and are used by the miners in mining the coal out of a "room"; while motor ties must be larger, since over them the heavy motors run which convey coal to the hoisting shaft. Room ties are about 5 feet in length, of any kind of hardwood, hewed on two sides, and with a 4 -inch by 6 -inch face. Motor ties are usually $51 / 2$ feet long, hewed on two sides, with a face 5 by 7 inches. Sometimes the smaller ties are sawed out by a portable mill. So far as we have seen, creosoted mine-props are not being used, since it is not intended that they shall give a service of over three or four years. For more permanent construction near shafts and in fluor-spar mines, cement or steel may be used.

4. Mine caps. "Cap pieces." These are pieces of boards of mixed oak, 1 inch by 6 inches by 16 inches in length, which are placed on top of mine props to tighten them up. Some of the sawmills use defective lumber for this purpose.

5. Wooden tracking. This is used in pieces usually 8 feet long and 3 by 4 inches in diameter, to take the place temporarily of rough or poor grade lumber which may be used to keep coal from falling down. It may be sawed at portable mills, and is worth about $\$ 20$ per thousand board feet.

6. Riprap lumber. This term is used to designate a kind of rough or cheap grade of lumber which may be used to keep coal from falling down in mines or is used in cars and may be sawed at portable mills. It is worth about $\$ 20$ per thousand board feet.

7. Lagging. Small round poles or poor grades of slabs from portable mills used to keep coal from falling through.

8. Sprags. Pieces of hardwood, preferably hickory, 2 inches in diameter and 18 inches long, used by miners to thrust between the spokes of coal cars to stop them.

Besides the kinds enumerated, large amounts of yellow pine and other kinds of lumber not considered here are used for tipples, sheds, buildings, and offices.

Amount of timber required to mine a ton of coal.-This is a very hard point to determine. One operator states that ten times as much timber is required in the Danville district to mine a ton of coal as in the Taylorville district, due largely to a difference in roof conditions.

Figuring it, however, by four different methods from data given us by some of the largest coal companies on timber used and coal mined for a single period, we find by averaging the figures from five different sources, that it takes not far from .25 cubic foot of timber to mine one ton of coal, or $20,000,000$ cubic feet for the whole state, not including lumber used for buildings and other construction purposes. Hall and Ingall's ('11) estimate that it takes one-fifth of a cubic foot of wood to mine one 
ton of coal, agrees very well with our figure. This amount is less than that given by some other authorities. Andros ('15) says that for "longwall mines" in District 1 , from 1.5 to 3 props per ton of coal are needed and for "Rooms and Pillar" timbering from 2 to 12 props per ton of coal, depending upon roof conditions.

\section{Forest Problems}

FIRES

Fire is the most important single factor affecting the forests of this region, and fires must be controlled before any policy looking towards the securing of a fully stocked forest can be made effective. Some part of the continuous timbered bluff area is burned over every year. The fall of 1921 was unfavorable for forest fires because of heavy rain at the usual fire period, but with the rank vegetation now on the ground the spring of 1923 if fairly dry will be a dangerous period. Out of 33 sections in different parts of this region examined during the summer of 1921 , 12 had burned over completely or partially within the last three years.

The forest-fire hazard is quite pronounced for several reasons. Where the stands are well stocked with mature trees, the forest floor is carpeted with leaves in autumn; and where the stands have been opened up too freely grass and weeds grow luxuriantly on the fertile soil. Hence, throughout the wooded area conditions favor burning. Also the continuity of the wooded areas in the bluffs permits fires to spread if once started, and it is almost certain that they will be started somewhere in the hills by hunters, by travelers, by settlers clearing land, by tie hackers or other woods workers who have no. interest in the woods, by farmers burning along the edges of the woods to kill chinch-bugs, by railroad engines, by incendiaries, or by lightning. Probably hunters set more fires than any other class. Fires also burn into the hills from the Mississippi bottoms.

\section{DIRECT EFFECTS OF FIRES}

The direct damage done by fires (Hawley '21) consists in the injury to trees containing merchantable material, the injury to young growth, including reproduction, injury to the soil, and injury to the productive power of the forests. A temperature of 54 degrees Centigrade (129.2 F.) is sufficient to kill the cambium or growing layer of a tree, this layer being very much more sensitive to heat during the early part of the growing season. Trees standing upon slopes are usually damaged worst on the uphill side, if the fire is sweeping up the slope, because that side is more sheltered temporarily and there is usually a greater accumulation of leaves and litter there at the base of the tree so that the fire burns longer and more severely. 
We have found trees over 12 inches breast high burned down by repeated fires, which means, of course, a direct loss of the merchantable timber in these trees. If not killed outright by the intense heat, young trees are fire-scarred, the wood is finally exposed by the peeling off of the bark, and an entrance point thus made for the spores of wood-destroying fungi which start decay at the base of the tree. In such timber a heavy discount must be allowed in making estimates. If left for seed, it is very unlikely that such trees will survive long or produce good crops.

\section{INJURY TO REPRODUCTION}

Fires kill the young growth outright, both of sprout and seedling origin, the amount of complete destruction depending on the thickness of the bark, the black oaks and hickories evidently being more fire-resistant than the white oaks. Repeated burning off of sprouts may cause an abnormal growth of young sprouts, too dense to amount to much in restocking the stand and only adding fuel to the next fire. Acorns, nuts, and other seeds are also so scorched and burned that they will not germinate no matter how favorable soil conditions may be; and the opening up of the stand through repeated fires hinders the reproduction of the better species brought into unfavorable competition with a covering growth of weeds, grass, and inferior species like sassafras, persimmon, and sumach. This fact of worthless growth, and the consequent drying out of the soil due to burning, is changing the beech-maple type of forest to the more xerophytic oak-hickory type.

INJURY TO THE SOIL

Prior to the work of Hesselman, the main value of humus in forest soils was thought to be its effect upon the physical characteristics of the soil, increasing its water-holding capacity, rendering heavy clay soils lighter and better aerated, and making sandy soils more retentive of moisture and heat. Moore ('22) shows that humus in soil or even in sand has a decided effect to stimulate the growth of tree seedlings of various pines and the sugar maple. He also says that "the nutrient value of humus and its influence on rate of growth in certain forests seems amply demonstrated. Surface-burning in a forest, by adding ashes to the soil. may stimulate growth temporarily; but since it destroys the nitrogen, which seems to be such a large factor, and allows the remaining nutrients to be rapidly carried off by rain, its ultimate result must be to seriously check growth." This may explain the low humus content of our upland timber soils in many counties as referred to by the Soil Survey. These soils have undergone repeated burning, coupled with a leaching out of their soluble humus content. 


\section{INJURY TO PRODUCTIVE POWER OF THE FOREST}

Another fact emphasized by one of our field party is the injury to other trees by a reduction in the density of stocking. Through this thinning-out process due to fires, the young trees that are left lose the benefit of competition with their neighbors. In restocking a forest the most desirable trees for timber are those which have a long, straight, well-pruned trunk and a short crown. Such trees are produced only by crowding when young and by the consequent struggle upwards for the light. Under present conditions there is no crowding during the sapling and pole stages so that the young trees branch close to the ground, with not enough side shade to kill off the side branches and thus to make good, clear lumber.

This reduction of density in stands of mature timber is shown best by our stand tables (Nos. 1 and 2, pp. 313, 314) for average acres at Alto Pass and Jonesboro, where we have 43.65 trees per acre 6 inches and above in one case, and only 33.32 in the other owing to fires and culling. Normal yield-tables for hardwoods of similar age show that we should have 130 trees or more per acre in order that they may properly utilize the soil and prune each other sufficiently. Data following in tables 9 and 10 obtained (a) near Ava, Illinois, in a tract which, according to statements of the owner, was 35 years old and had been burned over 8 years before, and $(b)$ from an unburned New England stand will bring out more strongly this diminution in the number of trees and the consequent loss of volume-growth which results.

Three quarter-acre plots were laid off in the Ava tract and the trees one inch and upwards in diameter were calipered. As can be seen in Table 9, the main species were white oak, black oak, and hickory, the percentages as follows:

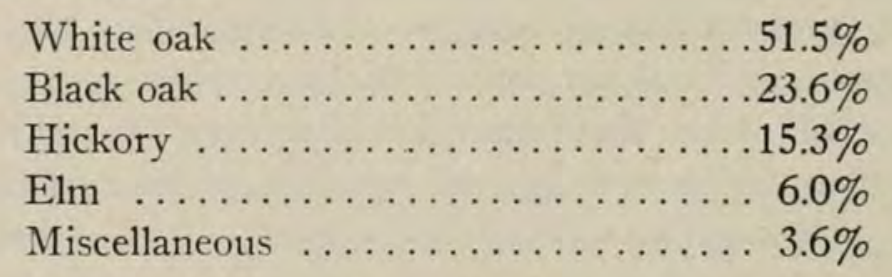

A comparison with an unburned inferior second-growth hardwood stand in New England (Spaeth, '20) thirty years old, is shown in Table 10 just below our figures for one acre of Ava woods. The sites, if compared on the average heights of the dominant trees, can be said to be fairly analogous, 34.4 feet in New England as against our 30 feet. A comparison of the basal areas of each acre shows that our stand was decidedly understocked, 85.3 square feet in New England as against 60.2 square feet for the Ava stand, this reduction in numbers resulting in a 
much smaller yield -9.8 cords per acre for the Ava stand and 20.63 cords for New England. The mean annual growth at Ava was only 21.3 cubic feet per acre for the 35 -year period as against 48.6 cubic feet in New England.

Table 9.-Data on Three 1/4-Acre Sample Plots-35-Year Stand, Upland

Type. Location, Sec. 8, Tr. 8 S., Range 4 W., Ava, Ill.

(Light Burn 8 Years Ago)

\begin{tabular}{|c|c|c|c|c|c|c|c|c|c|c|c|c|}
\hline \multirow[t]{2}{*}{$\begin{array}{l}\text { Diameter, } \\
\text { Inches }\end{array}$} & \multicolumn{2}{|c|}{$\begin{array}{l}\text { White } \\
\text { oak }\end{array}$} & \multicolumn{2}{|c|}{$\begin{array}{l}\text { Black } \\
\text { oak }\end{array}$} & \multicolumn{2}{|c|}{ Hickory } & \multicolumn{2}{|c|}{ Elm } & \multicolumn{2}{|c|}{$\begin{array}{l}\text { Miscel- } \\
\text { laneous }\end{array}$} & \multirow{3}{*}{ 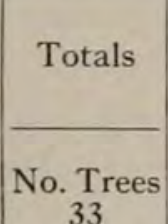 } & $\begin{array}{l}\text { Basal area } \\
\text { of stands } \\
\text { sq. } \mathrm{ft} .\end{array}$ \\
\hline & No. & Vol. & & Vol. & No. & Vol. & No. & Vol. & No. & Vol. & & \\
\hline 1 & 3 & cu. ft. & 2 & cu. ft. & 24 & cu. ft. & 3 & cu. ft. & 1 & cu. ft. & & . 198 \\
\hline 2 & 14 & 2.8 & 4 & .8 & 19 & 3.8 & 1 & .2 & 2 & .4 & 40 & .880 \\
\hline 3 & 47 & 18.8 & 25 & 10.0 & 6 & 2.4 & 3 & 1.2 & 2 & .8 & 83 & 4.117 \\
\hline 4 & 47 & 42.3 & 16 & 11.2 & 4 & 3.2 & 4 & 3.6 & 3 & 2.7 & 74 & 6.438 \\
\hline 5 & 40 & 56.0 & 15 & 21.0 & 2 & 2.6 & 4 & 5.6 & 4 & 5.6 & 65 & 8.840 \\
\hline 6 & 11 & 15.0 & 14 & 35.0 & 0 & & 5 & 12.5 & 0 & & 30 & 5.880 \\
\hline 7 & 12 & 40.8 & 9 & 30.6 & 0 & & 3 & 10.2 & 1 & 3.4 & 25 & 6.665 \\
\hline 8 & 13 & 57.2 & 2 & 8.8 & 2 & 8.8 & 0 & $\ldots$ & 1 & 4.4 & 18 & 6.282 \\
\hline 9 & 7 & 39.2 & 3 & 19.5 & 2 & 12.8 & & & & $\ldots$ & 12 & 5.304 \\
\hline 10 & 4 & 32.0 & 1 & 8.0 & & $\cdots$ & & & & & 5 & 2.725 \\
\hline 11 & 0 & & 0 & & & & & 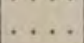 & & $\ldots$ & 0 & \\
\hline 12 & 1 & 13.0 & $\ldots$ & & 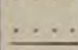 & $\cdots$ & $\ldots$ & $\cdots$ & $\ldots$ & $\ldots$ & 1 & .785 \\
\hline Totals & 199 & 327.1 & 91 & 144.9 & 59 & 34.6 & 23 & 34.3 & 14 & 17.3 & 386 & 48.21 \\
\hline
\end{tabular}

Table 10.-Comparison between Ava (Ill.) Stand aNd ONE IN NEW ENGLAND*

\begin{tabular}{c|c|c|c|c|c|c|c|c}
\hline \hline & $\begin{array}{c}\text { Total } \\
\text { number } \\
\text { of } \\
\text { trees }\end{array}$ & $\begin{array}{c}\text { Total } \\
\text { basal area } \\
\text { of stand } \\
\text { sq. ft. }\end{array}$ & $\begin{array}{c}\text { Average } \\
\text { height } \\
\text { in feet }\end{array}$ & $\begin{array}{c}\text { Total } \\
\text { volume } \\
\text { in } \\
\text { in. ft. }\end{array}$ & $\begin{array}{c}\text { Average } \\
\text { D.B.H. } \\
\text { inches }\end{array}$ & $\begin{array}{c}\text { Age } \\
\text { yrs. }\end{array}$ & $\begin{array}{c}\text { Volume } \\
\text { in } \\
\text { cords }\end{array}$ & $\begin{array}{c}\text { Mean } \\
\text { annual } \\
\text { growth } \\
\text { cu. ft. }\end{array}$ \\
\hline $\begin{array}{c}\text { Ava (III.) } \\
\text { 3/4-acre basis }\end{array}$ & 386 & 48.2 & 30 & 558.2 & $5.0^{\prime \prime}$ & 35 & 7.30 & 15.9 \\
One-acre basis & 441 & 60.2 & 30 & 747.7 & 5.0 & 35 & 9.8 & 21.3 \\
\hline $\begin{array}{c}\text { New England } \\
\text { 1-acre basis, } \\
\text { s e c o n d } \\
\text { g r o w t h } \\
\text { hardwoods. }\end{array}$ & 1,515 & 85.3 & 34.4 & 1,460 & 3.21 & 30 & 20.63 & 48.6 \\
\hline
\end{tabular}

\section{EFFECT OF SEVERE BURNING UPON YOUNG STANDS}

The effects of fire upon one stand are shown by the following figures, which were carefully taken on a quarter-acre plot in a thirty-year old stand where a severe fire had occurred in 1917. The trees were tallied, according to diameter, under two headings, "alive" and "dead," the diameter ranging from one inch to eight inches. We saw trees of this

*See Table 9 and pages 344-345. 
latter size which had been injured beyond any hope of recovery. As can be seen from the final figures, $70 \%$ of the stand had been killed, reducing the living trees from 632 to 188 per acre. A quarter-acre stand examined under similar conditions, but unburned, showed that there were on it 200 trees six inches and over in diameter, or 800 thrifty trees per acre.

Table 11.-Showing Fire Damage on 1/4-Acre Sample Plot, Burned in 1917, Section 8, TP. 8 S., Range 4 W., Near Ava.

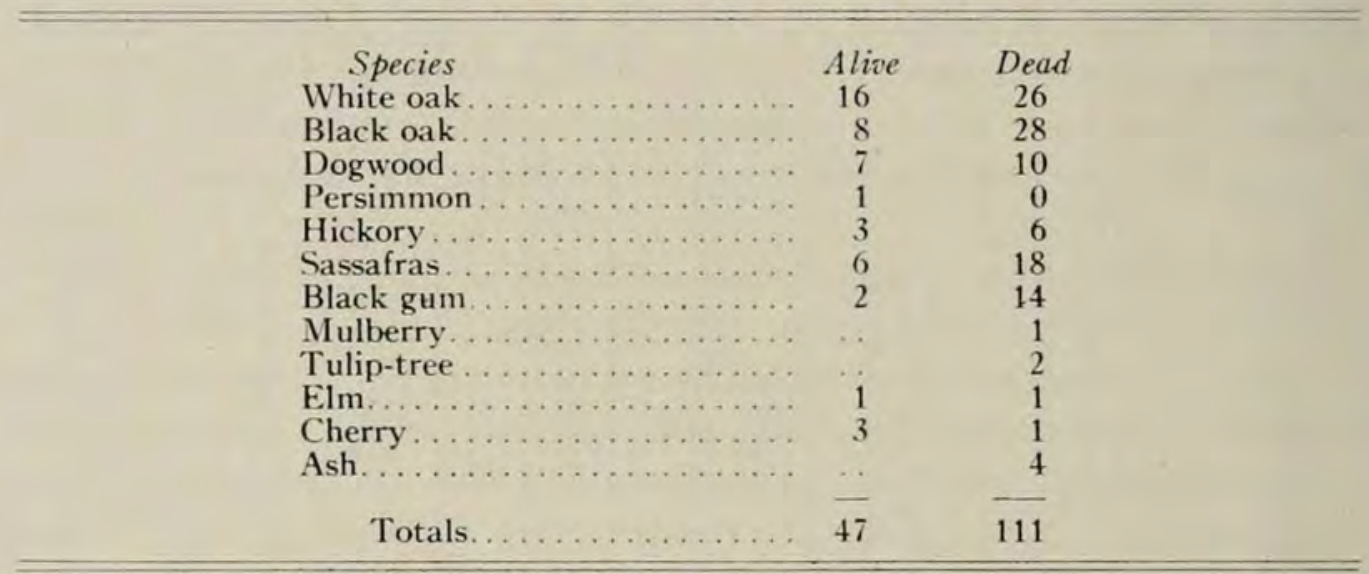

Per cent killed, $70 \%$

Note.-The total number of seedlings and saplings ranging in diameter from 1 inch to 8 inches, was 158 . or 632 per acre. The slope, exposed only in spots, was 30 degrees towards the north, ground grassy, with bare soil. Fire had resulted in a succession of sassafras, sumach, and grape-vines, with which the better species of seedlings would have to compete for light and growing space.

\section{Erosion}

Weller et al ('20), in speaking of topography and farming in Hardin county, say that not over half the total acreage is under cultivation and that gullying has followed the abandonment of the land. Steep slopes made cultivation difficult and also favored the washing away of the soil whose upper layers at least had been enriched by the organic matter deposited by the growth of plants and trees. They believe that for the future good of the county, "it would be well if all cleared lands having slopes of more than 600 feet per mile were reforested."

It seems that, in Union county at least, a separation of lands into those which will gully and those which will not on the basis of slope alone will hardly hold, since we have found erosion to be very serious on some long, gentle slopes of not over $5 \mathrm{r} / 2$ degrees, while other slopes of $23 \mathrm{de}-$ grees have withstood clearing and pasturing without showing serious signs of erosion. There are other factors which must be considered, such as the character of the soil and subsoil, the maintaining of the humus content of the soil by better methods of cropping, and the vigilance of the owner in filling up gullies as soon as they start. The disposition of gullied lands really brings up the question of an economic survey of such doubtful 
lands - a project which is a part of the program of the Natural History Survey.

Speaking of the encroachment of the forest upon the prairie through erosion along the water-courses, and of the fact that the organic matter in forest soils is only about 25 to 50 per cent of the amount present in adjoining prairie soils, Sampson ('21) says: "The farmers of the state have been slow in recognizing this effect of floral history upon the present value of soils. In my own community in the Southern Illinoisan glaciation the clearing and cultivation of forested areas seemed to have an alluring appeal entirely unrelated to economic values. Many of the farmers continued to clear the forest in spite of the fact that some of the forested areas after ten to fifteen years of cultivation yielded no better crops than adjacent prairie areas that had been cultivated for forty years. Many of the slopes formerly protected by forest vegetation have been cleared, farmed for a few years, and then abandoned to the forces of erosion. An intelligent constructive forest policy, that can be taught and convincingly explained to the farmers, is the only hope for remedying these regrettable conditions."

\section{GRAzING}

It is not the custom to graze the western section of the highlands where the wooded areas are extensive and relatively continuous. Here the clearings are fenced, while the wooded areas are not-probably because it involves too much trouble and expense. Unless opened up by heavy cuttings or repeated burning, the forest normally shades out the grasses so that very little pasturage is afforded. A heavy growth of grass or weeds indicates to the forester that the stand is not fully stocked, and our stand tables of the average acre for the Alto Pass and Jonesboro quadrangles, as cited previously, show this condition graphically. There is enough lime in the soil to favor the growth of blue grass, Japanese clover, blue stem, and sedge, and all of these varieties were found in the woods. It is unlikely that this rough wooded section will ever be made a field for cattle-raising on a large scale since the woods do not yield sufficient forage in dry seasons, and if cleared the extremely steep slopes will erode and form gullies.

Elsewhere in the highlands the woods generally occupy the slopes or ravines. Here the forests are more of the wood-lot type or else are strips along the slope. These wooded areas are often grazed to supplement the other pastures. Here grazing may cause serious ultimate loss, since the reproduction will be destroyed and grasses encouraged. The land has been kept in timber because it is too steep to clear, yet continued pasturing results in the disappearance of the timber and with it the top soils. 


\section{Forest Policy and Management}

The forestry problem in this region may be discussed with reference to three kinds of forest: (1) the large, more or less continuous tract of upland timber extending from Thebes to Chester which we have called the western region, which is most important for a future supply of crossties, mine props, and lumber; (2) farm wood-lots which are scattered and usually surrounded by roads; and (3) the overflow bottomlands, some already included in organized drainage projects, which will not be farmed for some years - at least not during the short rotation required to grow a timber crop of the faster-growing bottomland species.

\section{The Upland Timber Belt}

The upland timber belt presents some interesting problems. Dunlap ('21) mentions a fact in Missouri which finds its counterpart in this region, since this is a continuation of the Missouri Ozarks. He says that in this Missouri area there are from 5 to 10 millions of acres of timberland which are producing only three or four ties per acre per year when they might be producing ten ties per year. The technical side of timbergrowing in such a region is, according to him, quite easy, being largely a matter of suppressing forest fires and prohibiting grazing - at least while the areas are reproducing. A combination of forestry in the hills and farming in the narrow valleys will furnish employment for farmers in summer and for woods workers in winter, thus bringing about a better economic and social condition; whereas destruction of the timber means abandonment of many farms and decreased revenue to their owners.

Where private owners and companies do not take sufficient interest in these large tracts to protect them, the question is one of the wisdom of enforcing certain silvicultural requirements in the interest of the public - which undoubtedly is concerned in a permanent timber supply-or of state or other public ownership of such tracts. Whenever the time is ripe for the state to purchase these lands-after a careful valuation-to protect them from fire, to carry on improvement cuttings and thinningsthus affording at times a revenue to reduce the initial investment-and to hold them for a future timber supply and protection forest, this would be one possible solution. By means of its aggregation as a unit capable of successful forest-management, and its nearness to markets whose demands promise to increase rather than to diminish, the entire situation of this tract is both unique and strategic in Illinois, and we know of no other equal area in the state which combines like advantages.

OUTLINE OF PROPOSED FIRE-PROTECTION SYSTEM FOR UPLAND TIMBER BELT

In general, the attitude of these timber owners is favorable to protection, and their co-operation could be secured if they were convinced 
that effective protection could be given. The essential parts of such a system are fire prevention and fire control.

The necessary steps in the direction of fire prevention would be a campaign of education emphasizing the need of fire protection, and the posting of notices explaining the fire danger and the penalties for starting fires. Actual fire control will require (1) a centrally located station where a lookout may be established. At times during the fire season a lookout man might not be able to locate fires because the smoke in the hills makes seeing over five miles very difficult, and his main work would be telephoning over the district to find out about the presence of fires. (2) A division of the area into districts, with telephone connections from the lookout station, and a responsible person in each district closely in touch with woodland owners who will assist in assembling and organizing men for fire-fighting.

This system should work out about as follows: If any one notices a fire he telephones its location and probable size to the lookout man, who, in turn, calls up the district leader and gives him the details so far as he has learned them. The district leader summons local help and puts out the fire, which would usually not be difficult if fires are caught when they start, and the men properly equipped with tools. The lookout man would receive a monthly wage during the fire seasons of spring and fall, giving his entire time to the work. The district leader and the local fire fighters would be paid for the number of hours actually spent in fire-fighting. Such fires can be whipped out with brooms, burlap bags dipped in water, or green brush, and the most important point is to get to the fire early with from ten to twelve men. The keeping of important ridge trails and roads scraped bare might also be helpful wherever such roads and trails would serve as a means of stopping fires or as a vantage point for fighting them as they came up to the top of the ridge. So far as we have seen, these roads are well located for fire lines, and it would be neither a difficult nor an expensive matter to keep them open.

\section{The So-called Farm Wood-Lots}

The scattered farm wood-lots are being fairly well managed on the whole, many of them being held by the older citizens who see the advantage of conserving them and who are deriving some profit from the sale of timber at more or less regular intervals. Timber alone on forty acres of such land sells for $\$ 1,000$, or $\$ 25$ per acre, with no expense to the owner of handling it, aside from fire protection. Those farmers who do not appreciate the advantage to themselves or to others of taking care of their timber can be reached through the county farm advisers. 


\section{The Ovfrflow Bottomlands}

Since a very large proportion of the bottomlands of the Mississippi, Big Muddy, and Cache rivers yet in timber will in time be cleared and cultivated, the main work here consists of separating those areas which can not be drained from those which are true farming soils. Some of these stands, after they have been cut over by veneer or lumber companies, still contain a good stock of bottomland species which grow very rapidly and will soon be again of merchantable size. We have been told by a large manufacturer of veneer material in the Cache River district that he has enough of this kind of land with gum up to ten inches in diameter on the stump to supply a charcoal company with wood for ten years. Willow and cottonwood will likely dominate such stands after a partial clearing of the other hardwoods, and willow can be used for charcoal wood or excelsior, and cottonwood is now being marketed for soda pulp on the upper parts of the Mississippi and Illinois river bottoms. The erection of up-to-date wood-distillation plants and a pulp mill to use such bottomland hardwoods might apparently be a good business investment and distinctly favor forestry in this region. Besides, there is a demand for about 2,000,000 board feet of "softwoods" of the larger diameters coming from the veneer mills located in an important fruitgrowing section of the state; and we have been informed by operators of such mills that when the local supply of this bottomland timber is exhausted, which will probably be within five years, they will be compelled to move to Arkansas or Missouri, nearer the source of supply.

\section{Volume and Growth Studies}

The volume and growth of any species are best studied by making complete stem analyses of felled trees, since haphazard stump measurements are of little value, especially if made from a small number of trees. It was difficult to find in southern Illinois lumbering operations suited to the requirements for growth measurements, but two very good opportunities were afforded, one at Ava, and another at Indian Creek, near Murphysboro. One disadvantage in following the choppers is that logs are not cut by them in the ten-foot lengths preferred by the forester and the cutting is not carried up to a certain minimum top diameter, as the smallest diameter of the logs depends on the degree of utilization characteristic of the region. During the summer, however, complete stem analyses were made of 67 black oaks, 68 white oaks, and 33 trees classed as miscellaneous, along with many measurements for the volume tables. In the Appendix, pp. 367-371, are given the results obtained from these stem analyses of white and black oak, but a study of the growth of 
tulip-tree, hickory, sycamore, and other species must be deferred until more measurements are secured in this region. It is realized that the number of black and white oak trees is small, but it is believed that the figures are reliable for the area covered by our map.

\section{Stem Analysis}

For the benefit of those who are not familiar with the field measurements taken on an individual felled tree, a stem analysis blank such as was used is reproduced on page 352 , filled out as it was in the field by a party of three men. Two men make the required measurements for each section of the tree as sawn by the choppers, and a third makes the record. The diameter at $41 / 2$ feet above the ground (D. B. H.) can be taken with calipers before felling, or measured with a $4 \mathrm{~T} / 2$ foot stick held on the bole of the tree after felling.

It will be seen that this sheet contains all of the data necessary to a calculation of the growth of the tree in height, diameter, and volume, so the rest of the work can be done in the office. We have also the growth at different ages as shown at different heights above the ground. Since we know the diameter inside the bark and the length of each section, we have all the data needed to scale the logs by any $\log$ rule or to compute in cubic feet the volume of the separate logs, stump, or top. It will be noticed that the fifth section of this tree, left in the woods on account of crook, had a length of 12 feet and diameters at the ends inside the bark of 16.3 and 12.9 inches respectively, and that it scaled 61 board feet, and measured 9.84 cubic feet by the Smalian formula for computing volumes. By adding together the contents of all the unused pieces for the whole number of trees analyzed, a very reliable discount or "cull factor" for crook or rot can be obtained for any species, and this can be applied to the total estimate for that species.

The procedure in the office is as follows, and Graphs I (p. 372), III, IV, V, and VI illustrate some of the steps taken.

1. Separate the blanks into classes based on their D. B. H. (diameter breast-high); for example, putting 10.6-inch trees into the 11-inch class, 10.5 -inch trees into the 10 -inch class.

2. Make curves of height and D. I. B. (diameter inside bark) for each D. B. H. class represented, plotting D. I. B. at the top of each section as recorded, including the stump.

3. From the curves thus plotted, read off sets of D. I. B. tables for logs at $8,10,12,14$, etc., feet above an average stump height of 2 feet.

4. Harmonize the last readings by making curves for each 2- or 4foot section, based on diameters breast-high. Read off for final taper-table (see Table XII, App.), giving the D. I. B. at different heights above the 


\section{STEM ANALYSIS FIELD-SHEET}

Locality, Ava, Illinois Species, Tulip-tree

Date, Oct. 8, 1921

No. 69-Stump height, 3 feet

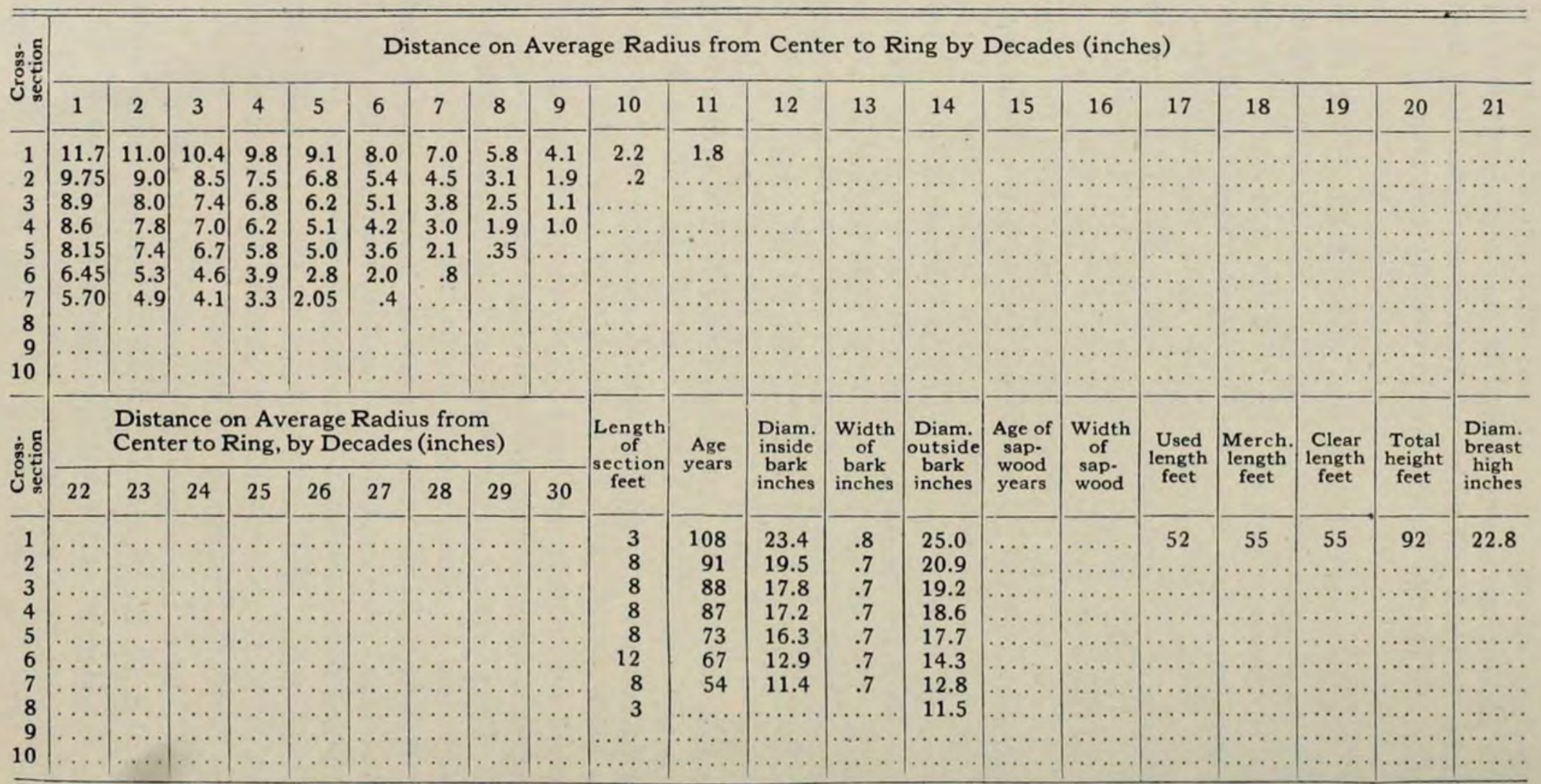


stump for different diameters breast-high. It can be seen that with such a table, which is a "taper table," the size of the average tree can easily be ascertained, and that all the data are in hand necessary for scaling its contents by any log rule or for computing its volume in cubic feet.

5. Plot curves of total and merchantable heights based on D. B. H. for both black and white oaks. Also make up tables from curves showing the board foot and cubic foot contents of trees based on D. B. H.

6. To get volumes based on age, plot the measurements taken under the heading "Distance on average radius from center to ring by decades" shown on the field sheet. Taking the stump section first, plot the diameter grown in ten years, by doubling the radius measurement each time. Diameter inside the bark is used as the ordinate and age as the abscissa for the curve.

7. Repeat the same procedure for the other sections, or logs, marked $1,2,3,4,5$, and 6 , on separate sheets of cross-section paper, and finally assemble all of these curves on one sheet. In this case the curves for different lengths are moved out to the age corresponding to the number of years required to grow up to that height from the ground.

8. With such a set of curves of diameter-growth at different heights, read off the time required to grow a $\log$ of any length or any top diameter inside the bark by following with the eye a line from the D. I. B. across to the curve representing the length desired. Project a line down from that curve to the base line and read the age required for the growth from the ground of such length of $\log$.

9. After this set of curves is made, the results can be read off to form a table, and the volume of the logs can be computed, since their top diameters and lengths are known.

As stated by Pegg ('19), working up the data from stem analysis sheets can be greatly facilitated by the use of an adding machine and a slide rule. 


\section{BIBLIOGRAPHY}

Andros, S. O.

1915. Coal mining in Illinois. Bul. 13, Ill. Coal Mining Investigations.

Baker, Willis, M.

1921. One cord an acre a year. Jour. Forestry, 19 (No. 7) : 755-756. Chapman, H. H.

1921. Forest mensuration. Wiley \& Sons, New York.

Colyer, Frank H.

1922. The geography of the Ozarks. Trans. Ill. Acad. Sci. 14: 36-43.

Deam, Charles C.

1915. Fifteenth Annual Report Indiana State Board of Forestry. Conservation Commission of Indiana.

1921. Trees of Indiana. Department of Conservation, State of Indiana, Publication 13. Indianapolis.

Dunlap, Frederick N.

1921. Growth of oak in the Ozarks. Research Bul. 41, Missouri Agr. Exp. Sta. Columbia, Mo.

Fuller, George D., and Miller, R. B.

1922. Forest conditions in Alexander county, Illinois. Trans. Ill. Acad. Sci. 14: 92-108.

Geer, W. C.

1907. Wood distillation. Forest Service Circular 114, U. S. Dept. Agr., Washington, D. C.

Graves, Henry S.

1921. New Hampshire and the new movement in forestry. Published by the Society for the Protection of New Hampshire Forests, 4 Joy Street, Boston.

Hall, R. C., and Ingall, O. D.

1911. Forest conditions in Illinois. Bul. Ill. State Lab. Nat. Hist., Vol. IX, Art. IV.

Hawley, L. F., and Palmer, R. C.

1914. Yields from the destructive distillation of certain hardwoods.

Bul. U. S. Dept. Agr. No. 129. 
Hawley, Ralph, C.

1921. The practice of silviculture, with particular reference to-its application in the United States. Wiley \& Sons, New York.

Lovejoy, P. S.

1919. The segregation of farm from forest land. Jour. Forestry, 17 (No. 6) : 645, 646.

\section{Moore, Barrington}

1922. Influence of certain soil factors on the growth of tree seedlings and wheat. Ecology, 3 (No. 1): 69-70.

Palmer, R. C.

1914. Distillation of hardwood. Compiled from bulletins of the

U. S. Forest Service. Forest Products Laboratory, Madison, Wisconsin.

Pegg, Ernest C.

1919. Mechanical aids in stem analysis. Jour. Forestry, 17 (No. 6) : 682-685.

Recknagel, A. B.

1916. A practical application of Pressler's formula. Forestry Quarterly, 14 (No. 2) : 263.

Ridgway, Robert

1883. Notes on the native trees of the lower Wabash and White River valleys in Illinois and Indiana. Proc. U. S. Nat'l Mus. 5: 49-88.

1895. Additional notes on the native trees of the lower Wabash Valley, Proc. U. S. Nat'l Mus. 17: 409-421.

Sampson, Homer C.

1921. An ecological survey of the prairie vegetation of Illinois. Bul.

Ill. State Nat. Hist. Surv. 13 (Art. 16) : 547-548.

Savage, T. E.

1908. The Lower Palaeozoic formations in southwestern Illinois. Am. Jour. Sci. 25 : 431-443.

1909. The Lower Palaeozoic formations in southwestern Illinois. Ibid. 28: 509-519.

1910. The Pre-Devonian of southern Illinois. Yearbook Ill. Geol. Surv., 1909, Bul. 16: 304-341.

1920. The Devonian formations of Illinois. Am. Jour. Sci. 49: 169-182.

Savage, T. E., and Shaw, E. W.

1912. Geological atlas of the United States, Murphysboro-Herrin folio. Surveyed in co-operation with the Geological Survey of Illinois. 
Seerey, Daniel F.

1918. Small sawmills, their equipment, construction and operation. Bul. 718, U. S. Dept. Agr. Contribution from the Forest Service, Washington, D. C.

Spaeth, J. Nelson

1920. Growth study and normal yield tables for second growth hardwood stands in New England. Harvard Forest Bul. No. 2. Petersham, Mass.

Trelease, Wm. T.

1896. Juglandaceae of the United States. Seventh Ann. Rep. Mo. Botanical Garden, p. 25.

Weller, Stuart, et al., in co-operation with the U. S. Geol. Survey 1920. The geology of Hardin county and the adjoining part of Pope county. Bul. 41, Ill. State Geol. Survey, pp. 43-44. Urbana, Illinois. 


\section{APPENDIX}

\section{Volume Tables for Leading Species, and Taper and Growth \\ Tables and Graphs for Black and White OAK}

From measurements taken on felled trees of leading species it was possible to make local volume tables for white and black oak. Since the number of field measurements made on trees of other species was not sufficient for the formation of a satisfactory basis for volume tables, it was thought wise to collect in the appendix the best tables extant for the other species which the wood-lot owner would ordinarily encounter. For convenience in citing to this article these tables are numbered consecutively beginning with one (I), but the original, author's, table-number, if any, is retained as facilitating reference to the table in its original connection.

\section{TABLE I*}

Table ViI.-Showing Total Height, Clear Length and Volume For Cypress of Different Diameters. Mississippi Bottoms

\begin{tabular}{|c|c|c|c|}
\hline $\begin{array}{l}\text { Diameter } \\
\text { Breast High } \\
\text { Inches }\end{array}$ & $\begin{array}{c}\text { Total } \\
\text { Height } \\
\text {-Feet }\end{array}$ & $\begin{array}{l}\text { Clear Length } \\
\text { Feet }\end{array}$ & $\begin{array}{c}\text { Volume } \\
\text { [Doyle Rule } \\
\text { Board Feet }\end{array}$ \\
\hline 10 & 78 & 4,3 & 89 \\
\hline 11 & 82 & 46 & 116 \\
\hline 12 & 85 & 49 & 147 \\
\hline 13 & 88 & 53 & 184 \\
\hline 14 & 90 & 56 & 231 \\
\hline 15 & 93 & 59 & 280 \\
\hline 16 & 95 & 62 & 336 \\
\hline 17 & 97 & 65 & 399 \\
\hline 18 & 100 & 68 & 468 \\
\hline 19 & 102 & 71 & 546 \\
\hline 20 & 104 & 73 & 632 \\
\hline 21 & 106 & 76 & 715 \\
\hline 22 & 108 & 79 & 817 \\
\hline 23 & 109 & 81 & 928 \\
\hline 24 & 111 & 83 & 1,037 \\
\hline 25 & 113 & 85 & 1,153 \\
\hline 26 & 114 & 87 & 1,277 \\
\hline 27 & 116 & 89 & 1,309 \\
\hline 28 & 117 & 91 & 1,551 \\
\hline 29 & 119 & 92 & 1,700 \\
\hline 30 & 120 & 93 & 1,840 \\
\hline 31 & 122 & 94 & 1,986 \\
\hline 32 & 123 & 95 & 2,139 \\
\hline 33 & 124 & 96 & 2,290 \\
\hline 34 & 125 & 97 & 2,450 \\
\hline 35 & 126 & 97 & 2,620 \\
\hline 36 & 128 & 98 & 2,800 \\
\hline
\end{tabular}

*From the Woodsman's Handbook. Part 1, by Henry S. Graves, U. S. Department of Agriculture, Bureau of Forestry, Bulletin No. 36, 1903. 
TABLE II*

Tulip Tree (Yellow Poplar)

\begin{tabular}{|c|c|c|c|}
\hline $\begin{array}{l}\text { Age } \\
\text { Years }\end{array}$ & $\begin{array}{l}\text { D. B. H. } \\
\text { Outside Bark } \\
\text { Inches }\end{array}$ & $\begin{array}{l}\text { Height } \\
\text { Feet }\end{array}$ & $\begin{array}{c}\text { Volume } \\
\text { [Doyle Rule] } \\
\text { Board Feet }\end{array}$ \\
\hline 60 & 10 & 78 & 22 \\
\hline 68 & 11 & 82 & 32 \\
\hline 75 & 12 & 86 & 47 \\
\hline 82 & 13 & 89 & 63 \\
\hline 90 & 14 & 92 & \\
\hline 97 & 15 & 95 & 113 \\
\hline 104 & 16 & 97 & 150 \\
\hline 112 & 17 & 99 & 190 \\
\hline 120 & 18 & 101 & 238 \\
\hline 128 & 19 & 103 & 290 \\
\hline 136 & 20 & 104 & 352 \\
\hline 144 & 21 & 105 & 420 \\
\hline 152 & 22 & 106 & 490 \\
\hline 160 & 23 & 107 & 565 \\
\hline 169 & 24 & 107 & 644 \\
\hline 178 & 25 & 108 & 725 \\
\hline 186 & 26 & 108 & 813 \\
\hline 195 & 27 & 109 & 905 \\
\hline 204 & 28 & 109 & 1,002 \\
\hline 212 & 29 & 110 & 1,106 \\
\hline 221 & 30 & 110 & 1,215 \\
\hline 230 & 31 & 111 & 1,327 \\
\hline 240 & 32 & 111 & 1,445 \\
\hline 248 & 33 & 112 & 1,563 \\
\hline 258 & 34 & 112 & 1,685 \\
\hline 267 & 35 & 113 & 1,811 \\
\hline 276 & 36 & 113 & 1,940 \\
\hline 286 & 37 & 113 & 2,074 \\
\hline 296 & 38 & 114 & 2,210 \\
\hline 306 & 39 & 114 & 2,342 \\
\hline 317 & 40 & 115 & 2,475 \\
\hline
\end{tabular}

*From measurements taken on 403 trees in Scottfand Anderson counties, Tennessee, by F. E. Olmsted, of the.U. S. Forest Service. 
TABLE III*

"Table 8 gives cubic contents of hickory trees according to diameter and merchantable length. It is based upon the measurements of 630 trees. By its use the total contents of a tree may be estimated without reference to the individual logs."

TABLE 8-Cubic contents of hickory according to diameter and merchantable length.

\begin{tabular}{|c|c|c|c|c|c|c|c|c|c|c|c|c|c|c|}
\hline \multirow{3}{*}{$\begin{array}{c}\text { Diameter } \\
\text { breast- } \\
\text { high- } \\
\text { inches }\end{array}$} & \multicolumn{13}{|c|}{ Merchantable length-feet } & \multirow{3}{*}{$\begin{array}{c}\text { Diam. } \\
\text { eter } \\
\text { inside } \\
\text { bark of } \\
\text { top- } \\
\text { inches }\end{array}$} \\
\hline & 5 & 10 & 15 & 20 & 25 & 30 & 35 & 40 & 45 & 50 & 55 & 60 & 65 & \\
\hline & \multicolumn{13}{|c|}{ Volume-cubic feet } & \\
\hline 5. & 1.0 & 1.8 & 2.3 & & & & & & & & & & & 4 \\
\hline $6 .$. & 1.3 & 2.5 & 3.2 & 3.6 & & & & & & & & & & 5 \\
\hline $7 \ldots$ & 1.6 & 3.2 & 4.2 & 5.0 & 5.7 & & & .. & .. & & & $\cdots$ & $\cdots$ & 6 \\
\hline $8 \ldots$ & 2.0 & 4.0 & 5.4 & 6.5 & 7.5 & & & $\cdots$ & $\begin{array}{l}\cdots \\
\text {. }\end{array}$ & & & & $\ldots \ldots$ & 6 \\
\hline $9 .$. & 2.5 & 4.8 & 6.6 & 8.2 & 9.6 & 10.0 & & .... & ... & & ...... & $\ldots \ldots$ & $\ldots \ldots$ & 7 \\
\hline $10 \ldots$ & 3.0 & 5.8 & 8.1 & 10.0 & 11.5 & 13.0 & & ... & ...... & ... & .... & ...... & $\ldots \ldots$ & 8 \\
\hline 11. & 3.5 & 6.9 & 9.7 & 12.0 & 14.0 & 16.0 & 18.0 & & & & & & & 8 \\
\hline $12 \ldots$ & 4.1 & 8.0 & 11.5 & 14.5 & 17.0 & 20.0 & 21.5 & 23.5 & & & & & & 9 \\
\hline $13 \ldots \ldots$ & 4.8 & 9.3 & 13.5 & 17.0 & 20.5 & 23.5 & 26.0 & 28.5 & 31 & & & & & 10 \\
\hline $14 \ldots \ldots$ & 5.5 & 10.5 & 15.5 & 20.0 & 24.0 & 27.5 & 31.0 & 34.0 & 37 & & & & ....... & 11 \\
\hline $15 \ldots$ & 6.2 & 12.0 & 17.5 & 23.0 & 27.5 & 32.0 & 36.0 & 39.0 & 43 & . & & & ...... & 11 \\
\hline $16 \ldots$ & 7.0 & 14.0 & 20.0 & 26.5 & 31.0 & 36.0 & 41.0 & 45.0 & 50 & 54 & & & ....... & 12 \\
\hline $17 \ldots$ & 8.0 & 15.5 & 23.0 & 29.5 & 36.0 & 41.0 & 46.0 & 51.0 & 56 & 61 & 66 & & & 13 \\
\hline $18 \ldots$ & ...... & 17.5 & 25.5 & 33.0 & 40.0 & 46.0 & 52.0 & 58.0 & 63 & 69 & 74 & & $\ldots$ & 14 \\
\hline $19 \ldots$ & ....... & 19.5 & 28.5 & 37.0 & 45.0 & 52.0 & 58.0 & 64.0 & 70 & 76 & 82 & & & 14 \\
\hline $20 \ldots$ & $\ldots \ldots$ & 21.5 & 32.0 & 41.0 & 50.0 & 57.0 & 64.0 & 71.0 & 78 & 84 & 90 & 97 & 103 & 15 \\
\hline $21 \ldots$ & ....... & 24,0 & 35.0 & 45.0 & 54.0 & 63.0 & 71.0 & 79.0 & 86 & 93 & 100 & 107 & 113 & 16 \\
\hline 22 . & ...... & 26.0 & 38.0 & 50.0 & 60.0 & 69.0 & 77.0 & 86.0 & 94 & 102 & 110 & 118 & 126 & 16 \\
\hline 23. & & 28.5 & 42.0 & 54.0 & 65.0 & 75.0 & 84.0 & 93.0 & 102 & 111 & 120 & 128 & 137 & 17 \\
\hline $24 \ldots$ & & 31.0 & 45.0 & 59.0 & 70.0 & 81.0 & 91.0 & 102.0 & 111 & 121 & 130 & 139 & 148 & 18 \\
\hline $25 \ldots$ & $\ldots .$. & 34.0 & 49.0 & 64.0 & 76.0 & 88.0 & 99.0 & 110.0 & 121 & 130 & 140 & 149 & 158 & 19 \\
\hline $26 \ldots$ & & 36.5 & 53.0 & 69.0 & 82.0 & 95.0 & 107.0 & 119.0 & 130 & 140 & 151 & 161 & 171 & 19 \\
\hline 27 . & & ........ & 57.0 & 74.0 & 89.0 & 103.0 & 116.0 & 128.0 & 140 & 151 & 162 & 173 & 183 & 20 \\
\hline $28 \ldots \ldots$ & & ....... & 61.0 & 80.0 & 97.0 & 112.0 & 125.0 & 137.0 & 149 & 161 & 173 & 185 & 197 & 20 \\
\hline
\end{tabular}

*From Bulletin 80, Forest Service, U. S. Department of Agriculture, "The Commercial Hickories," by Anton T. Boisen and J. A. Newlin, 1910. 
TABLE IV*

Table No. 16 -Volume Table for Red Maple

\begin{tabular}{|c|c|c|c|c|c|c|c|c|}
\hline \multirow{2}{*}{$\begin{array}{c}\text { Diam- } \\
\text { eter, } \\
\text { breast } \\
\text { high } \\
\text { (inches) }\end{array}$} & \multicolumn{7}{|c|}{ Total height of tree (feet) } & \multirow{2}{*}{$\begin{array}{c}\text { Basis } \\
\text { (trees) }\end{array}$} \\
\hline & 20 & 30 & 40 & 50 & 60 & 70 & 80 & \\
\hline $\begin{array}{r}2, \ldots \\
3, \ldots \\
4, \ldots \\
5, \ldots \\
6, \ldots \\
7, \ldots \\
8, \ldots \\
9, \ldots \\
10, \ldots \\
11, \ldots \\
12, \ldots \\
13, \ldots \\
14, \ldots \\
15, \ldots \\
16, \ldots \\
17, \ldots\end{array}$ & $\begin{array}{c}\text { Cu.Ft. } \\
0.25 \\
.60 \\
1.00 \\
- \\
- \\
- \\
- \\
- \\
- \\
- \\
= \\
= \\
- \\
-\end{array}$ & $\begin{array}{c}\text { Cu. Ft. } \\
0.35 \\
.71 \\
1.30 \\
2.15 \\
- \\
- \\
- \\
- \\
- \\
- \\
- \\
- \\
- \\
- \\
-\end{array}$ & $\begin{array}{c}\text { Cu. Ft. } \\
0.55 \\
1.00 \\
1.65 \\
2.40 \\
3.45 \\
4.70 \\
6.05 \\
7.65 \\
- \\
= \\
= \\
= \\
= \\
= \\
= \\
-\end{array}$ & $\begin{array}{c}\text { Cu. Ft. } \\
-. .2 \\
1.2 \\
2.0 \\
3.0 \\
4.3 \\
5.9 \\
7.8 \\
10.1 \\
12.7 \\
15.6 \\
18.9 \\
22.6 \\
26.8 \\
31.5 \\
36.6 \\
-\end{array}$ & \begin{tabular}{|c|} 
Cu. Ft. \\
- \\
- \\
- \\
3.6 \\
5.2 \\
7.1 \\
9.4 \\
12.0 \\
15.0 \\
18.5 \\
22.5 \\
26.8 \\
31.6 \\
37.0 \\
43.2 \\
-
\end{tabular} & $\begin{array}{c}\text { Cu. Ft. } \\
- \\
- \\
- \\
\overline{6} \\
6.2 \\
8.4 \\
10.8 \\
13.5 \\
16.7 \\
20.5 \\
24.8 \\
29.7 \\
35.0 \\
40.7 \\
47.0 \\
-\end{array}$ & $\begin{array}{c}\text { Cu. Ft. } \\
- \\
- \\
- \\
- \\
- \\
- \\
11.8 \\
14.8 \\
18.2 \\
22.0 \\
26.4 \\
31.4 \\
36.7 \\
42.7 \\
49.7 \\
58.4\end{array}$ & $\begin{array}{r}59 \\
51 \\
36 \\
38 \\
42 \\
25 \\
39 \\
28 \\
20 \\
23 \\
10 \\
9 \\
8 \\
3 \\
4 \\
2\end{array}$ \\
\hline
\end{tabular}

*This volume table was constructed by E. E. Carter and first published in the Bulletin of the Harvard Forestry Club, Vol. 2, 1913. A revised and enlarged form of it appeared in "The Northern Hardwood Forest: Its Composition, Growth and Management." Bul. 285 of the U. S. Dept. of Agr., pp. 61-63. 
TABLE V

Composite Volume-Table for White Oak Contents in Board Feet

\begin{tabular}{|c|c|c|c|c|}
\hline $\begin{array}{l}\text { D. B. H. } \\
\text { inches }\end{array}$ & $\begin{array}{l}\text { Ava table } \\
\text { (Maine rule) }\end{array}$ & $\begin{array}{c}\text { Maryland table } \\
\text { (Maine rule) }\end{array}$ & $\begin{array}{l}\text { By Doyle- } \\
\text { Scribner rule }\end{array}$ & $\begin{array}{l}\text { By Doyle-Scrib- } \\
\text { ner rule, plus } \\
25 \% \text { over-run }\end{array}$ \\
\hline $\begin{array}{r}8 \\
9 \\
10 \\
11 \\
12 \\
13 \\
14 \\
15 \\
16 \\
17 \\
18 \\
19 \\
20 \\
21 \\
22 \\
23 \\
24 \\
25 \\
26\end{array}$ & $\begin{array}{r}9 \\
18 \\
28 \\
41 \\
51 \\
77 \\
97 \\
120 \\
147 \\
172 \\
222 \\
245 \\
285 \\
323 \\
366 \\
413 \\
464 \\
520 \\
582\end{array}$ & $\begin{array}{r}4 \\
15 \\
20 \\
25 \\
50 \\
65 \\
80 \\
100 \\
150 \\
175 \\
210 \\
235 \\
260 \\
295 \\
325 \\
465 \\
510 \\
560 \\
600\end{array}$ & $\begin{array}{r}2 \\
4 \\
10 \\
16 \\
24 \\
34 \\
48 \\
65 \\
84 \\
105 \\
143 \\
168 \\
207 \\
243 \\
281 \\
329 \\
372 \\
426 \\
467\end{array}$ & $\begin{array}{r}2 \\
5 \\
12 \\
20 \\
30 \\
42 \\
60 \\
81 \\
105 \\
131 \\
169 \\
210 \\
259 \\
304 \\
350 \\
411 \\
465 \\
532 \\
584\end{array}$ \\
\hline
\end{tabular}

N. B.-The figures in column 4 of the table give what an average tree of a certain diameter should actually saw out at the mill. The difference between what it saws out and its scale in the woods or on the log-deck is called "over-run." The figures in column 2 were derived from contents of trees measured at Ava, Jackson county, scaled by the Maine rule. The figures in column 3 of the table were secured from State Forester F. W. Besley, for white oak trees in Maryland which were scaled by the Maine rule. 
TABLE VI*

Composite Volume-Table for Black OAK Contents in Board Feet

\begin{tabular}{c|c|c|c|c}
\hline \hline $\begin{array}{c}\text { D. B. H., } \\
\text { inches }\end{array}$ & $\begin{array}{c}\text { Ava table } \\
\text { (Maine rule) }\end{array}$ & $\begin{array}{c}\text { Maryland } \\
\text { table } \\
\text { (Maine rule) }\end{array}$ & $\begin{array}{c}\text { By Doyle- } \\
\text { Scribner rule }\end{array}$ & $\begin{array}{c}\text { By Doyle-Scribner } \\
\text { rule, plus 25\% } \\
\text { over-run }\end{array}$ \\
\cline { 2 - 3 } 8 & & & & \\
\hline 9 & 20 & 12 & 4 & 5 \\
10 & 39 & 15 & 15 & 19 \\
11 & 51 & 20 & 20 & 25 \\
12 & 64 & 30 & 28 & 35 \\
13 & 103 & 45 & 37 & 46 \\
14 & 129 & 55 & 51 & 64 \\
15 & 154 & 105 & 70 & 101 \\
16 & 185 & 120 & 89 & 136 \\
17 & 215 & 140 & 111 & 230 \\
18 & 263 & 165 & 184 & 271 \\
19 & 289 & 240 & 217 & 324 \\
20 & 344 & 275 & 259 & 470 \\
21 & 394 & 315 & 304 & 511 \\
22 & 455 & 355 & 376 & 580 \\
23 & 506 & 400 & 409 & 756 \\
24 & 560 & 445 & 464 & 814 \\
25 & 621 & 490 & 515 & 900 \\
26 & 695 & 550 & 605 & 998 \\
27 & 770 & 605 & 651 & 1,125 \\
28 & 845 & 665 & 720 & \\
29 & 920 & 725 & 798 & \\
30 & 1,000 & 805 & 900 & \\
\hline
\end{tabular}

*The explanations below preceding table for white oak, are also applicable to this table. 
TABLE VII*

Volume Table for Red OAK

(Based on 130 Trees Measured at New Haven, Conn.)

\begin{tabular}{|c|c|c|c|c|c|c|c|c|}
\hline \multirow{3}{*}{$\begin{array}{l}\text { Diam- } \\
\text { eter } \\
\text { breast } \\
\text { high, } \\
\text { inches }\end{array}$} & \multicolumn{8}{|c|}{ Height of tree in feet } \\
\hline & 20 & 25 & 30 & 35 & 40 & 45 & 50 & 55 \\
\hline & \multicolumn{8}{|c|}{ Merchantable cord-wood in cubic feet $[\dagger]$} \\
\hline 5 & 1. 23 & 1.61 & 1.91 & 2.24 & 2.55 & 2.91 & 3.12 & 3.40 \\
\hline 6 & 1.78 & 2.31 & 2.83 & 3.31 & 3.77 & 4.22 & 4.61 & 5.04 \\
\hline 7 & & & 3.79 & 4.40 & 5.08 & 5.68 & 6.25 & 6.79 \\
\hline 8 & & ....... & 4.88 & 5.75 & 6.56 & 7.31 & 7.99 & 8.75 \\
\hline 9 & & & & & 8.31 & 9.27 & 10.13 & 10.97 \\
\hline 10 & & & & & & & 12.62 & 13.64 \\
\hline 11 & & & & & & & 15.70 & 16.87 \\
\hline
\end{tabular}

TABLE VII* (continued)

\begin{tabular}{|c|c|c|c|c|c|c|c|}
\hline \multirow{3}{*}{$\begin{array}{c}\text { Diameter } \\
\text { breast } \\
\text { high, } \\
\text { inches }\end{array}$} & \multicolumn{7}{|c|}{ Height of tree in feet } \\
\hline & 60 & 65 & 70 & 75 & 80 & 85 & 90 \\
\hline & \multicolumn{7}{|c|}{ Merchantable cord-wood in cubic feet } \\
\hline 5 & 3.66 & & & & & & \\
\hline 6 & 5.45 & 5.81 & 6.16 & & & & \\
\hline 7 & 7.32 & 7.81 & 8.31 & 8.78 & 9.27 & & \\
\hline 8 & 9.43 & 10.07 & 10.70 & 11.31 & 11.93 & & \\
\hline 9 & 11.76 & 12.62 & 13.31 & 14.04 & 14.75 & & \\
\hline 10 & 14.63 & 15.62 & 16.52 & 17.42 & 18.30 & 19.20 & \\
\hline 11 & 18.04 & 19.16 & 20.18 & 21.17 & 22.15 & 23.12 & 24.06 \\
\hline 12 & 12.33 & 23.62 & 24.90 & 26.04 & 27.15 & 28.16 & 29.14 \\
\hline 13 & 27.33 & 28.85 & 30.34 & 31.62 & 32.98 & 34.21 & 35.40 \\
\hline
\end{tabular}

*From "Forest Mensuration," by Henry S. Graves.

tCubic feet can be converted into corde by dividing by 90 . 
TABLE VIII*

Table 7.-Black Willow-Mississippi Valley [Doyle Rule]

\begin{tabular}{|c|c|c|c|c|c|c|c|c|c|c|}
\hline \multirow{3}{*}{$\begin{array}{l}\text { Diam- } \\
\text { eter } \\
\text { breast- } \\
\text { high }\end{array}$} & \multicolumn{8}{|c|}{ Total height of tree - feet } & \multirow{3}{*}{$\begin{array}{l}\text { Diam- } \\
\text { eter } \\
\text { inside } \\
\text { bark } \\
\text { of top }\end{array}$} & \multirow{3}{*}{ Basis } \\
\hline & 60 & 70 & 80 & 90 & 100 & 110 & 120 & 130 & & \\
\hline & \multicolumn{8}{|c|}{ Volume-board feet } & & \\
\hline $\begin{array}{c}\text { Inches } \\
14\end{array}$ & 52 & 64 & 82 & 100 & 130 & 140 & & & $\begin{array}{c}\text { Inches } \\
10\end{array}$ & $\begin{array}{l}\text { Trees } \\
\ldots .\end{array}$ \\
\hline & 60 & 80 & 100 & 120 & 150 & 160 & & & 11 & \\
\hline 16 & 68 & 97 & 120 & 150 & 170 & 180 & 190 & & 12 & 3 \\
\hline 17 & 73 & 110 & 150 & 170 & 190 & 210 & 220 & & 12 & 11 \\
\hline 18 & 79 & 130 & 170 & 200 & 220 & 240 & 250 & 270 & 13 & 9 \\
\hline 19 & & 150 & 200 & 230 & 250 & 270 & 290 & 310 & 14 & 6 \\
\hline 20 & & 180 & 230 & 270 & 290 & 310 & 330 & 350 & 14 & 12 \\
\hline 21 & & 200 & 260 & 300 & 330 & 360 & 370 & 390 & 15 & 23 \\
\hline 22 & & 230 & 290 & 340 & 370 & 400 & 420 & 440 & 16 & 25 \\
\hline 23 & & 260 & 330 & 380 & 410 & 450 & 470 & 490 & 17 & 23 \\
\hline 24 & & 290 & 360 & 420 & 460 & 500 & 520 & 540 & 17 & 23 \\
\hline 25 & & & 400 & 470 & 510 & 550 & 570 & 600 & 18 & 15 \\
\hline 26 & & & 450 & 510 & 560 & 600 & 620 & 660 & 19 & 15 \\
\hline 27 & & & 490 & 560 & 610 & 650 & 680 & 710 & 19 & 16 \\
\hline 28 & & & 540 & 610 & 660 & 710 & 740 & 770 & 20 & 9 \\
\hline 29 & & & 590 & 660 & 720 & 760 & 800 & 840 & 21 & 7 \\
\hline 30 & & & 650 & 710 & 770 & 820 & 860 & 900 & 22 & 8 \\
\hline 31 & & & & 760 & 820 & 880 & 920 & 970 & & 8 \\
\hline 32 & & & & 810 & 870 & 940 & 990 & 1,040 & 23 & 3 \\
\hline 33 & & & & 860 & 920 & 1,000 & 1,050 & 1,100 & 24 & 6 \\
\hline 34 & & & & 920 & 980 & 1,060 & 1,120 & 1,170 & 24 & 3 \\
\hline \multirow{3}{*}{$\begin{array}{l}35 \\
36\end{array}$} & & & & 970 & 1,030 & 1,120 & 1,190 & 1,240 & 25 & 1 \\
\hline & & & & 1,020 & 1,090 & 1,180 & 1,250 & 1,310 & 26 & 1 \\
\hline & & & & & & & & & & 229 \\
\hline
\end{tabular}
Lamb.

*From Bul. No. 316. U. S. Dept. Agr.: "Willows: their Growth, Use and Importance," by George N. 
TABLE IX

Frothingham, 1915

VOlume TABLE-BeEch

U. S. Forest Service Bulletin No. 285

Michigan: Based on 285 trees

\begin{tabular}{|c|c|c|c|c|c|c|c|}
\hline \multirow{3}{*}{$\begin{array}{c}\text { D.B.H.ob } \\
\text { in } \\
\text { inches }\end{array}$} & \multicolumn{7}{|c|}{ Merchantable Volume in Board Feet } \\
\hline & \multicolumn{7}{|c|}{ Number of 16 -foot logs } \\
\hline & 1 & $11 / 2$ & 2 & $21 / 2$ & 3 & $31 / 2$ & 4 \\
\hline 10 & 22 & 32 & 47 & 67 & 87 & 110 & \\
\hline 11 & 25 & 36 & 52 & 77 & 100 & 130 & \\
\hline 12 & 29 & 42 & 61 & 91 & 120 & 150 & 170 \\
\hline 13 & 35 & 50 & 74 & 110 & 140 & 170 & 200 \\
\hline 14 & 42 & 60 & 92 & 130 & 170 & 200 & 230 \\
\hline 15 & 50 & 75 & 120 & 160 & 200 & 230 & 270 \\
\hline 16 & & & 150 & 190 & 230 & 270 & 310 \\
\hline 17 & & & 180 & 220 & 270 & 310 & 360 \\
\hline 18 & & & 220 & 260 & 310 & 350 & 410 \\
\hline 19 & & & . & 290 & 350 & 400 & 460 \\
\hline 20 & & & & 330 & 390 & 450 & 510 \\
\hline 21 & & & & 370 & 430 & 500 & 570 \\
\hline 22 & & & C. & 400 & 470 & 560 & 640 \\
\hline 23 & & & & 440 & 520 & 610 & 710 \\
\hline 24 & & & $\ldots$ & 490 & 570 & 670 & 780 \\
\hline 25 & & & & 530 & 620 & 740 & 870 \\
\hline
\end{tabular}

TABLE $\mathrm{X}$

Volume Table-BeEch

Waha and Cheever, 1903

New York: Based on 485 trees

Merchantable Volume in Standard Railroad Ties

\begin{tabular}{c|c||c|c}
\hline D.B.H. ob, inches & $\begin{array}{c}\text { Number of } \\
\text { standard ties, } \\
7^{\prime \prime} \times 9^{\prime \prime} \times 8^{\prime}\end{array}$ & D.B.H. ob, inches & $\begin{array}{c}\text { Number of } \\
\text { Nundard ties, } \\
\text { stand } \\
7^{\prime \prime} \times 9^{\prime \prime} \times 8^{\prime}\end{array}$ \\
\cline { 1 - 2 } 12 & 1 & 22 & 7 \\
13 & 2 & 23 & 8 \\
14 & 3 & 24 & 9 \\
15 & 3 & 25 & 10 \\
16 & 3 & 26 & 11 \\
17 & 4 & 27 & 11 \\
18 & 4 & 29 & 13 \\
19 & 5 & 30 & 14 \\
20 & 6 & & \\
\hline
\end{tabular}


TABLE XI*

Table 9.-Showing Total Height, Clear Length and Volume for Different Diameters of Cottonwood Growing in Mississippi Bottoms

\begin{tabular}{|c|c|c|c|}
\hline $\begin{array}{l}\text { Diameter } \\
\text { Breast High } \\
\text { inches }\end{array}$ & $\begin{array}{l}\text { Total height } \\
\text { feet }\end{array}$ & $\begin{array}{c}\text { Clear length, } \\
\text { feet }\end{array}$ & $\begin{array}{c}\text { Volume } \\
\text { board feet }[\dagger]\end{array}$ \\
\hline $\begin{array}{r}6 \\
7 \\
8 \\
9 \\
10 \\
11 \\
12 \\
13 \\
14 \\
15 \\
16 \\
17 \\
18 \\
19 \\
20 \\
21 \\
22 \\
23 \\
24 \\
25 \\
26 \\
27 \\
28 \\
29 \\
30 \\
31 \\
32 \\
33 \\
34 \\
35 \\
36 \\
37\end{array}$ & $\begin{array}{r}58 \\
65 \\
72 \\
78 \\
83 \\
86 \\
93 \\
97 \\
101 \\
105 \\
109 \\
113 \\
116 \\
119 \\
122 \\
125 \\
127 \\
130 \\
132 \\
134 \\
136 \\
138 \\
140 \\
141 \\
143 \\
144 \\
146 \\
147 \\
148 \\
149 \\
150 \\
151\end{array}$ & $\begin{array}{l}24 \\
28 \\
31 \\
34 \\
36 \\
38 \\
40 \\
42 \\
44 \\
46 \\
47 \\
48 \\
50 \\
51 \\
52 \\
53 \\
54 \\
54 \\
55 \\
56 \\
56 \\
57 \\
57 \\
58 \\
58 \\
58 \\
59 \\
59 \\
59 \\
59 \\
59 \\
59\end{array}$ & $\begin{array}{r}. \\
. \\
. \\
. \\
20 \\
40 \\
60 \\
85 \\
115 \\
145 \\
180 \\
225 \\
275 \\
340 \\
405 \\
480 \\
560 \\
645 \\
735 \\
820 \\
910 \\
1,000 \\
1,090 \\
1,175 \\
1,265 \\
1,360 \\
1,450 \\
1,540 \\
1,635 \\
1,725 \\
1,820\end{array}$ \\
\hline
\end{tabular}

*Compiled by S. J. Record.

†Doyle Rule 
Table XiI.-Taper Table for White OAK, Ava, Illinois

\begin{tabular}{|c|c|c|c|c|c|c|c|c|c|c|c|c|c|}
\hline \multirow{3}{*}{$\begin{array}{l}\text { D.B.H. } \\
\text { Inches }\end{array}$} & \multicolumn{13}{|c|}{ Feet above the Stump } \\
\hline & 8 & 10 & 12 & 14 & 16 & 20 & 24 & 28 & 30 & 32 & 36 & 40 & 42 \\
\hline & \multicolumn{13}{|c|}{ Diameters inside Bark (inches) } \\
\hline 6 & 4.6 & 4.3 & 4.1 & $\ldots$ & & $\ldots$ & $\cdots$ & $\ldots$ & $\ldots$ & $\ldots$ & $\ldots$ & $\ldots$ & $\ldots$ \\
\hline 7 & 5.6 & 5.1 & 4.9 & $\ldots$ & 4.3 & & $\ldots$ & $\ldots$ & $\ldots$ & $\ldots$ & $\ldots$ & $\ldots$ & $\ldots$ \\
\hline 8 & 6.4 & 5.9 & 5.7 & & 5.1 & 4.4 & 4.0 & $\ldots$ & $\ldots$ & $\ldots$ & $\ldots$ & $\ldots$ & $\ldots$ \\
\hline 9 & 7.3 & 6.8 & 6.5 & 6.2 & 5.9 & 5.1 & 4.7 & $\ldots$ & $\ldots$ & $\ldots$ & $\ldots$ & $\ldots$ & $\ldots$ \\
\hline 10 & 8.1 & 7.6 & 7.3 & 7.0 & 6.7 & 5.9 & 5.5 & $\ldots$ & $\cdots$ & $\ldots$ & $\ldots$ & $\ldots$ & $\ldots$ \\
\hline 11 & 9.0 & 8.4 & 8.1 & 7.8 & 7.5 & 6.7 & 6.3 & $\cdots$ & $\ddot{q} \ddot{0}$ & $\ldots$ & $\cdots$ & $\cdots$ & $\ldots$ \\
\hline 12 & 9.8 & 9.2 & 9.0 & 8.6 & 8.4 & 7.5 & 7.1 & $\begin{array}{l}6.1 \\
60\end{array}$ & 6.0 & $\because \ddot{i}$ & $\cdots$ & $\cdots$ & $\ldots$ \\
\hline 13 & 10.7 & 10.0 & 9.7 & 9.4 & 9.2 & 8.3 & 7.9 & 6.9 & 6.8 & 6.4 & & $\ldots$ & $\ldots$ \\
\hline 14 & 11.5 & 10.9 & 10.5 & 10.2 & 10.0 & 9.1 & 8.7 & 7.8 & 7.6 & 7.2 & 6.8 & & $\ldots$ \\
\hline 15 & 12.3 & 11.7 & 11.3 & 10.9 & 10.9 & 10.0 & 9.5 & 8.6 & 8.4 & 8.0 & 7.6 & 6.2 & $\ldots$ \\
\hline 16 & 13.2 & 12.5 & 12.1 & 11.8 & 11.8 & 10.8 & 10.3 & 9.4 & 9.2 & 8.8 & 8.4 & 7.0 & $\ldots$ \\
\hline 17 & 14.0 & 13.3 & 12.9 & 12.6 & 12.6 & 11.6 & 11.1 & 10.2 & 10.0 & 9.6 & 9.2 & 7.8 & 6.3 \\
\hline 18 & 14.9 & 14.1 & 13.7 & 13.4 & 13.4 & 12.4 & 11.9 & 11.0 & 10.8 & 10.4 & 10,0 & 8.6 & 7.2 \\
\hline 19 & 15.7 & 15.0 & 14.5 & 14.2 & 14.1 & 13.3 & 12.7 & 11.8 & 11.6 & 11.2 & 10.8 & 9.4 & 8.1 \\
\hline 20 & 16.6 & 15.9 & 15.3 & 15.0 & 15.0 & 14.0 & 13.5 & 12.6 & 12.4 & 12.0 & 11.5 & 10.2 & 9.0 \\
\hline 21 & 17.4 & 16.7 & 16.1 & 15.8 & 16.5 & 14.7 & 14.3 & 13.4 & 13.2 & 12.8 & 12.2 & 11.0 & 9.9 \\
\hline 22 & 18.3 & 17.5 & 17.0 & 16.6 & 16.6 & 15.5 & 15.1 & 14.2 & 14.0 & 13.6 & 13.0 & 11.8 & 10.8 \\
\hline 23 & 19.1 & 18.3 & 17.8 & 17.5 & 17.5 & 16.3 & 15.9 & 15.0 & 14.8 & 14.4 & 13.7 & 12.7 & 11.7 \\
\hline 24 & 19.9 & 19.1 & 18.6 & 18.3 & 18.3 & 17.1 & 16.7 & 15.8 & 15.6 & 15.1 & 14.4 & 13.5 & 12.6 \\
\hline 25 & 20.8 & 20.0 & 19.4 & 19.1 & 19.1 & 18.0 & 17.5 & 16.6 & 16.4 & 15.9 & 15.2 & 14.3 & 13.5 \\
\hline 26 & 21.7 & 20.8 & 20.2 & 20.0 & 20.0 & 18.8 & 18.3 & 17.4 & 17.2 & 16.5 & 15.9 & 15.1 & 14.4 \\
\hline 27 & 22.5 & 21.7 & 21.1 & 20.8 & 20.8 & 19.6 & 19.1 & 18.2 & 18.0 & 17.4 & 16.6 & 15.6 & 15.3 \\
\hline 28 & 23.3 & 22.5 & 21.9 & 21.7 & 21.7 & 20.4 & 19.9 & 19.0 & 18.8 & 18.2 & 17.4 & 16.7 & 16.2 \\
\hline
\end{tabular}

NOTE.-A taper table shows the diameter inside the bark at specified heights above the stump, the average stump height in this case being taken as two feet. With such a table one can read for a tree with a given diameter breast-high outside the bark (o.b.) its size inside the bark at $8,10,12,14$, 16 , etc., feet above estimating top diameters of railroad ties. Volume tables in board-foot or cubic-foot units can also be easily made from good taper tables. 
Table Xili.-Taper Table for Black Oak, Ava, Illinois

\begin{tabular}{|c|c|c|c|c|c|c|c|c|c|c|c|c|c|}
\hline \multirow{3}{*}{$\begin{array}{l}\text { D. B.H. } \\
\text { Inches }\end{array}$} & \multicolumn{13}{|c|}{ Feet above the Stump } \\
\hline & 8 & 10 & 12 & 14 & 16 & 20 & 24 & 28 & 30 & 32 & 36 & 40 & 42 \\
\hline & \multicolumn{13}{|c|}{ Diameters inside Bark (inches) } \\
\hline 8 & 7.2 & 7.0 & 6.7 & 6.4 & 6.0 & 5.5 & $\ldots$ & & $\ldots$ & & $\ldots$ & & \\
\hline 9 & 8.1 & 7.8 & 7.5 & $\begin{array}{l}0.4 \\
7.2\end{array}$ & $\begin{array}{l}0.0 \\
6.9\end{array}$ & $\begin{array}{l}5.5 \\
6.3\end{array}$ & & $\because$ & & $\cdots$ & $\cdots$ & $\cdots$ & $\cdots$ \\
\hline 10 & 8.9 & 8.6 & 8.3 & 8.0 & 7.7 & 7.1 & 6.5 & & $\ldots \ldots$ & $\ldots$ & $\ldots$ & $\ldots$ & $\ldots$ \\
\hline 11 & 9.7 & 9.4 & 9.1 & 8.8 & 8.5 & 7.9 & 7.3 & 6.7 & .... & $\ldots$ & $\cdots$ & $\cdots$ & $\cdots$ \\
\hline 12 & 10.5 & 10.2 & 10.0 & 9.6 & 9.3 & 8.7 & 8.1 & 7.5 & & $\cdots$ & $\ldots$ & $\ldots$ & $\ldots$ \\
\hline 13 & 11.3 & 11.0 & 10.7 & 10.4 & 10.1 & 9.5 & 8.9 & 8.3 & 8.1 & $\ldots$ & $\ldots$ & $\ldots$ & $\ldots$ \\
\hline 14 & 12.1 & 11.8 & 11.6 & $\begin{array}{l}11.2 \\
11.2\end{array}$ & 11.0 & 10.3 & $\begin{array}{l}0.9 \\
9.7\end{array}$ & 9.1 & 8.9 & 8.6 & $\ldots$ & $\ldots$ & $\ldots$ \\
\hline 15 & 12.9 & 12.6 & 12.4 & 12.0 & 11.7 & 11.1 & 10.5 & 10.0 & 9.7 & 9.4 & $\ldots$ & $\ldots \ldots$ & $\ldots$ \\
\hline 16 & 13.7 & 13.4 & $\begin{array}{l}13.4 \\
13.2\end{array}$ & 12.8 & 12.5 & 12.0 & 11.4 & 10.8 & 10.5 & 10.2 & 9.6 & $\ldots$ & $\ldots$ \\
\hline 17 & 14.6 & 14.2 & 14.0 & 13.6 & 13.3 & 12.8 & 12.2 & 11.6 & 11.3 & 11.0 & 10.4 & $\ldots$ & $\ldots$ \\
\hline 18 & 15.4 & 15.0 & 14.8 & 14.4 & 14.2 & 13.6 & 13.0 & 12.4 & 12.1 & 11.8 & 11.2 & & $\ldots$ \\
\hline $\begin{array}{l}10 \\
19\end{array}$ & 16.2 & 15.8 & 15.6 & 15.2 & 15.0 & 14.4 & 13.8 & 13.2 & 13.0 & 12.6 & 12.0 & 11.4 & $\cdots$ \\
\hline 20 & 17.0 & 16.6 & 16.4 & 16.1 & 15.8 & 15.2 & 14.6 & 14.0 & 13.8 & 13.4 & 12.8 & 12.2 & \\
\hline 21 & 17.8 & 17.5 & 17.2 & 16.9 & $\begin{array}{l}16.6 \\
\text { S }\end{array}$ & 16.0 & 15.4 & 14.8 & 14.6 & 14.2 & 13.7 & 13.1 & 12.8 \\
\hline 22 & 18.6 & 18.3 & 18.0 & 17.7 & 17.4 & 16.8 & $\begin{array}{l}1.4 \\
16.2\end{array}$ & 15.6 & 15.4 & 15.0 & 14.5 & 13.9 & 13.6 \\
\hline 23 & 19.4 & 19.1 & 18.8 & 18.5 & 18.2 & 17.6 & 17.0 & $\begin{array}{l}16.4 \\
\end{array}$ & $\begin{array}{l}16 . \\
16.2\end{array}$ & 15.8 & 15.3 & 14.7 & 14.5 \\
\hline 24 & 20.3 & 19.9 & 19.6 & 19.3 & 19.0 & 18.4 & 17.9 & 17.2 & 17.0 & 16.6 & 16.1 & 15.5 & 15.3 \\
\hline 25 & 21.1 & 20.7 & 20.4 & 20.1 & 19.8 & 19.2 & 18.7 & 18.0 & 17.8 & 17.4 & 17.0 & 16.3 & 16.1 \\
\hline 26 & 21.9 & 21.6 & 21.3 & 20.9 & 20.7 & 20.1 & 19.5 & 18.9 & 18.6 & 18.3 & 17.8 & 17.1 & 16.9 \\
\hline 27 & 22.7 & 22.4 & 22.1 & 21.7 & 21.5 & 20.9 & 20.3 & 19.7 & 19.4 & 19.1 & 18.6 & 18.0 & 17.7 \\
\hline 28 & 23.5 & 23.2 & 22.9 & 22.5 & 22.3 & 21.7 & 21.1 & 20.5 & 20.2 & 20.0 & 19.4 & 18.8 & 18.6 \\
\hline 29 & 24.3 & 24.0 & 23.7 & 23.3 & 23.1 & 22.5 & 21.9 & 21.3 & 21.0 & 20.8 & 20.2 & $\begin{array}{l}10.0 \\
19.6\end{array}$ & $\begin{array}{l}10.0 \\
19.4\end{array}$ \\
\hline 30 & 25.1 & 25.8 & 24.5 & 24.2 & 24.0 & 23.4 & 22.8 & 22.2 & 21.9 & 21.6 & 21.1 & 20.5 & 20.2 \\
\hline
\end{tabular}


TABLE XIV

Black Oak Growth-Table, showing Total Height, Age on Stump, and Volume in Cubic Feet and Board Feet based on

D. B. H., Ava, Illinois

\begin{tabular}{|c|c|c|c|c|c|c|}
\hline $\begin{array}{l}\text { D.B.H. } \\
\text { inches }\end{array}$ & $\begin{array}{l}\text { Age on } \\
\text { stump, } \\
\text { years }\end{array}$ & $\begin{array}{l}\text { Total } \\
\text { height, } \\
\text { feet }\end{array}$ & $\begin{array}{c}\text { Total } \\
\text { volume, } \\
\text { cu. } \mathrm{ft} .\end{array}$ & $\begin{array}{l}\text { Merchant- } \\
\text { able }\end{array}$ & $\begin{array}{l}\text { Volume in } \\
\text { board feet, } \\
\text { (Ava table*) }\end{array}$ & $\begin{array}{c}\text { No. of } \\
\text { trees } \\
\text { measured }\end{array}$ \\
\hline $\begin{array}{r}6 \\
7 \\
8 \\
9 \\
10 \\
11 \\
12 \\
13 \\
14 \\
15 \\
16 \\
17 \\
18 \\
19 \\
20 \\
21 \\
22 \\
23 \\
24 \\
25 \\
26 \\
27 \\
28 \\
29 \\
30\end{array}$ & $\begin{array}{r}45 \\
51 \\
56 \\
62 \\
67 \\
73 \\
76 \\
79 \\
83 \\
86 \\
89 \\
93 \\
96 \\
99 \\
102 \\
106 \\
109 \\
112 \\
114 \\
117 \\
119 \\
121 \\
123 \\
125 \\
127\end{array}$ & $\begin{array}{l}35 \\
39 \\
43 \\
46 \\
50 \\
53 \\
57 \\
60 \\
64 \\
67 \\
70 \\
72 \\
74 \\
76 \\
78 \\
80 \\
81 \\
82 \\
83 \\
84 \\
84 \\
84 \\
84 \\
84 \\
85\end{array}$ & $\begin{array}{r}7.00 \\
7.50 \\
11.50 \\
15.00 \\
19.50 \\
25.00 \\
30.00 \\
35.50 \\
42.50 \\
49.50 \\
57.50 \\
65.00 \\
72.50 \\
80.00 \\
87.50 \\
95.00 \\
103.00 \\
110.00 \\
117.50 \\
125.00 \\
137.50 \\
157.50 \\
178.00\end{array}$ & $\begin{array}{r}4.00 \\
6.00 \\
8.00 \\
11.00 \\
14.50 \\
18.50 \\
22.50 \\
26.00 \\
30.00 \\
35.50 \\
41.00 \\
47.50 \\
54.00 \\
61.00 \\
68.00 \\
75.00 \\
82.50 \\
90.00 \\
97.50 \\
107.00 \\
117.00 \\
127.00 \\
140.00\end{array}$ & $\begin{array}{r}20 \\
39 \\
51 \\
64 \\
83 \\
103 \\
129 \\
154 \\
178 \\
215 \\
263 \\
298 \\
344 \\
394 \\
455 \\
506 \\
560 \\
621 \\
695 \\
770 \\
845 \\
920 \\
1,000\end{array}$ & $\begin{array}{l}1 \\
1 \\
1 \\
1 \\
1 \\
1 \\
6 \\
6 \\
6 \\
7 \\
7 \\
3 \\
8 \\
6 \\
6 \\
4 \\
4 \\
2 \\
2 \\
1 \\
1 \\
1 \\
1 \\
2 \\
1\end{array}$ \\
\hline & & & & & & Tot. 68 \\
\hline
\end{tabular}

The results in column 6 were obtained from averages of trees scaled by the Maine rule. 
TABLE XV

White Oak Growth-Tarle, showing Total Height, Age on Stump, and Volume in Cubic and Board Feet based on D. B. H. Ava, Illinois

\begin{tabular}{|c|c|c|c|c|c|c|}
\hline \multirow{2}{*}{$\begin{array}{l}\text { D.B.H. } \\
\text { inches }\end{array}$} & \multirow{2}{*}{$\begin{array}{l}\text { Age on } \\
\text { stump } \\
\text { years }\end{array}$} & \multirow{2}{*}{$\begin{array}{l}\text { Total } \\
\text { height }\end{array}$} & \multicolumn{2}{|c|}{ Volume in cubic feet } & \multirow{2}{*}{$\begin{array}{l}\text { Board feet* } \\
\text { (Ava table) }\end{array}$} & \multirow{2}{*}{$\begin{array}{c}\text { Number o } \\
\text { trees } \\
\text { measured }\end{array}$} \\
\hline & & & Total & $\begin{array}{l}\text { Merchant- } \\
\text { able }\end{array}$ & & \\
\hline $\begin{array}{r}6 \\
7 \\
8 \\
9 \\
10 \\
11 \\
12 \\
13 \\
14 \\
15 \\
16 \\
17 \\
18 \\
19 \\
20 \\
21 \\
22 \\
23 \\
24 \\
25 \\
26\end{array}$ & $\begin{array}{r}60 \\
63 \\
66 \\
70 \\
74 \\
80 \\
86 \\
94 \\
103 \\
111 \\
120 \\
130 \\
140 \\
150 \\
160 \\
170 \\
180 \\
191 \\
201 \\
211 \\
222\end{array}$ & $\begin{array}{l}34 \\
39 \\
44.5 \\
48 \\
52 \\
54.5 \\
57.5 \\
59.5 \\
62 \\
64 \\
66 \\
68 \\
69.5 \\
71 \\
72.5 \\
73.5 \\
74.5 \\
75.5 \\
76.5 \\
77.5 \\
78\end{array}$ & $\begin{array}{r}7.5 \\
8.5 \\
9.5 \\
11.0 \\
12.5 \\
14.5 \\
16.5 \\
20.5 \\
25.0 \\
32.0 \\
39.0 \\
46.5 \\
54.0 \\
61.0 \\
68.5 \\
76.5 \\
82.5 \\
90.5 \\
99.0 \\
107.0 \\
116.0\end{array}$ & $\begin{array}{l}4 \\
5.5 \\
6.5 \\
7.5 \\
8.5 \\
10.5 \\
12.5 \\
15 \\
18 \\
23 \\
27.5 \\
33 \\
38 \\
43 \\
49 \\
55 \\
61.5 \\
68 \\
75 \\
82 \\
89\end{array}$ & $\begin{array}{r}r \\
5 \\
9 \\
18 \\
28 \\
41 \\
57 \\
77 \\
97 \\
120 \\
147 \\
172 \\
222 \\
245 \\
285 \\
323 \\
366 \\
413 \\
464 \\
520 \\
582\end{array}$ & $\begin{array}{r}2 \\
4 \\
4 \\
7 \\
6 \\
10 \\
8 \\
1 \\
1 \\
1 \\
2 \\
4 \\
3 \\
0 \\
2 \\
4 \\
2 \\
2 \\
1 \\
3 \\
1 \\
\text { Tot. } 68\end{array}$ \\
\hline
\end{tabular}

*The results in column 6 were obtained from averages of trees scaled by the Maine rule. 
TABLE XVI

Taper Table for Black OAK (All-aged Stand) READ FROM GRAPH V

\begin{tabular}{|c|c|c|c|c|c|c|c|c|}
\hline $\begin{array}{c}\text { Age } \\
\text { years }\end{array}$ & $\begin{array}{l}\text { Diameter } \\
\text { on stump } \\
\text { inside } \\
\text { bark, } \\
\text { inches }\end{array}$ & $\begin{array}{c}\text { Diameter } \\
\text { breast- } \\
\text { high out- } \\
\text { sidebark, } \\
\text { inches }\end{array}$ & $\begin{array}{l}\text { Diameter } \\
\text { at } 8 \mathrm{ft} \text {. } \\
\text { above } \\
\text { stump in- } \\
\text { sidebark, } \\
\text { inches }\end{array}$ & $\begin{array}{l}\text { Diameter } \\
\text { at } 16 \mathrm{ft} . \\
\text { above } \\
\text { stump }\end{array}$ & $\begin{array}{c}\text { Diameter } \\
\text { at } 24 \mathrm{ft} . \\
\text { above } \\
\text { stump }\end{array}$ & $\begin{array}{l}\text { Diameter } \\
\text { at } 32 \mathrm{ft} \text {. } \\
\text { above } \\
\text { stump }\end{array}$ & $\begin{array}{l}\text { Diameter } \\
\text { at } 40 \mathrm{ft} . \\
\text { above } \\
\text { stump }\end{array}$ & $\begin{array}{c}\text { Volume } \\
\text { in } \\
\text { cubic } \\
\text { feet }\end{array}$ \\
\hline 10 & .6 & 0 & 0 & 0 & 0 & 0 & 0 & \\
\hline 20 & 20 & 1.5 & 1.0 & 0 & 0 & 0 & 0 & .112 \\
\hline 30 & 3.3 & 3,2 & 2.4 & 1.3 & .2 & 0 & 0 & .88 \\
\hline 40 & 5.0 & 5.1 & 4.0 & 3.0 & 1.9 & .7 & 0 & 1.70 \\
\hline 50 & 6.6 & 6.8 & 5.7 & 4.6 & 2.6 & 2.5 & 0 & 3.72 \\
\hline 60 & 8.4 & 8.6 & .7 .5 & 6.2 & 5.1 & 4.3 & 2.0 & 7.71 \\
\hline 70 & 10.2 & 10.5 & 9.2 & 8.0 & 6.8 & 6.0 & 4.4 & 12.75 \\
\hline 80 & 13.0 & 13.2 & 11.4 & 10.2 & 9.0 & 8.1 & 6.8 & 21.31 \\
\hline 90 & 16.2 & 16.2 & 13.9 & 12.7 & 11.6 & 10.4 & 9.2 & 33.51 \\
\hline 100 & 19.2 & 19.2 & 16.2 & 15.1 & 14.1 & 12.8 & 11.8 & 48.3 \\
\hline 110 & 22.0 & 221 & 18.8 & 17.7 & 16.4 & 15.4 & 14.2 & 67.2 \\
\hline 120 & 24.5 & 24.9 & 21.2 & 19.8 & 18.6 & 17.4 & 16.3 & 83.9 \\
\hline 130 & 26.2 & 26.6 & 22.8 & 21.6 & 20.4 & 19.3 & 18.2 & 98.56 \\
\hline
\end{tabular}

TABLE XVII

Taper Table for White Oak (All-aged Stand)

READ From Graph VI

\begin{tabular}{|c|c|c|c|c|c|c|c|c|}
\hline $\begin{array}{l}\text { Age } \\
\text { years }\end{array}$ & $\begin{array}{c}\text { Diameter } \\
\text { on stump } \\
\text { inside } \\
\text { bark, } \\
\text { inches }\end{array}$ & $\begin{array}{c}\text { Diameter } \\
\text { breast- } \\
\text { high out- } \\
\text { sidebark, } \\
\text { inches }\end{array}$ & $\begin{array}{l}\text { Diameter } \\
8 \mathrm{ft} . \\
\text { above } \\
\text { stump }\end{array}$ & $\begin{array}{c}\text { Diameter } \\
16 \mathrm{ft} . \\
\text { above } \\
\text { stump }\end{array}$ & $\begin{array}{l}\text { Diameter } \\
24 \mathrm{ft} . \\
\text { above } \\
\text { stump }\end{array}$ & $\begin{array}{l}\text { Diameter } \\
32 \mathrm{ft} . \\
\text { above } \\
\text { stump }\end{array}$ & $\begin{array}{c}\text { Diameter } \\
40 \mathrm{ft} . \\
\text { above } \\
\text { stump }\end{array}$ & $\begin{array}{c}\text { Volume } \\
\text { in } \\
\text { cubic } \\
\text { feet }\end{array}$ \\
\hline 10 & 2 & 0 & 0 & 0 & 0 & 0 & 0 & \\
\hline 20 & .8 & 0 & 0 & 0 & 0 & 0 & 0 & \\
\hline 30 & 1.7 & 1.0 & 0 & 0 & 0 & 0 & 0 & \\
\hline 40 & 3.0 & 2.2 & 1.0 & 0 & 0 & 0 & 0 & \\
\hline 50 & 4.8 & 3.8 & 2.7 & 1.6 & 0 & 0 & 0 & .96 \\
\hline 60 & 6.8 & 6.2 & 4.6 & 3.6 & 2.3 & .4 & 0 & 2.61 \\
\hline 70 & 8.8 & 9.0 & 7.3 & 5.9 & 4.7 & 2.7 & 1.2 & 7.32 \\
\hline 80 & 11.6 & 10.1 & 9.0 & 7.5 & 6.3 & 4.4 & 3.0 & 11.79 \\
\hline 90 & 13.0 & 12.6 & 10.2 & 8.8 & 7.5 & 5.9 & 4.2 & 15.96 \\
\hline 100 & 14.1 & 13.8 & 11.3 & 9.8 & 8.4 & 7.0 & 5.2 & 20.32 \\
\hline 110 & 15.3 & 14.9 & 12.2 & 10.8 & 9.4 & 8.0 & 6.2 & 24.16 \\
\hline 120 & 16.3 & 16.0 & 13.1 & 11.7 & 10.2 & 8.8 & 7.1 & 31.3 \\
\hline 130 & 17.3 & 17.0 & 14.0 & 12.6 & 11.1 & 9.6 & 7.9 & 32.7 \\
\hline 140 & 18.2 & 18.0 & 14.9 & 13.4 & 11.9 & 10.4 & 8.6 & 37.65 \\
\hline 150 & 19.2 & 18.9 & 15.7 & 14.2 & 12.7 & 11.2 & 9.4 & 42.03 \\
\hline 160 & 20.2 & 19.9 & 16.6 & 15.0 & 13.5 & 12.0 & 10.2 & 47.24 \\
\hline 170 & 21.1 & 21.0 & 17.4 & 15.8 & 14.3 & 12.8 & 11.0 & 52.52 \\
\hline 180 & 22.0 & 21.9 & 18.3 & 16.6 & 15.1 & 13.6 & 11.8 & 58.26 \\
\hline 190 & 22.8 & 22.9 & 19.1 & 17.4 & 15.8 & 14.3 & 12.7 & 63.80 \\
\hline 200 & 23.8 & 23.8 & 19.9 & 18.2 & 16.5 & 15.1 & 13.5 & 68.90 \\
\hline 210 & 24.7 & 24.7 & 20.7 & 19.1 & 17.3 & 15.8 & 14.3 & 73.35 \\
\hline 220 & 25.5 & 25.5 & 21.5 & 19.9 & 18.1 & 16.4 & 15.0 & 82.58 \\
\hline
\end{tabular}


GRAPH I

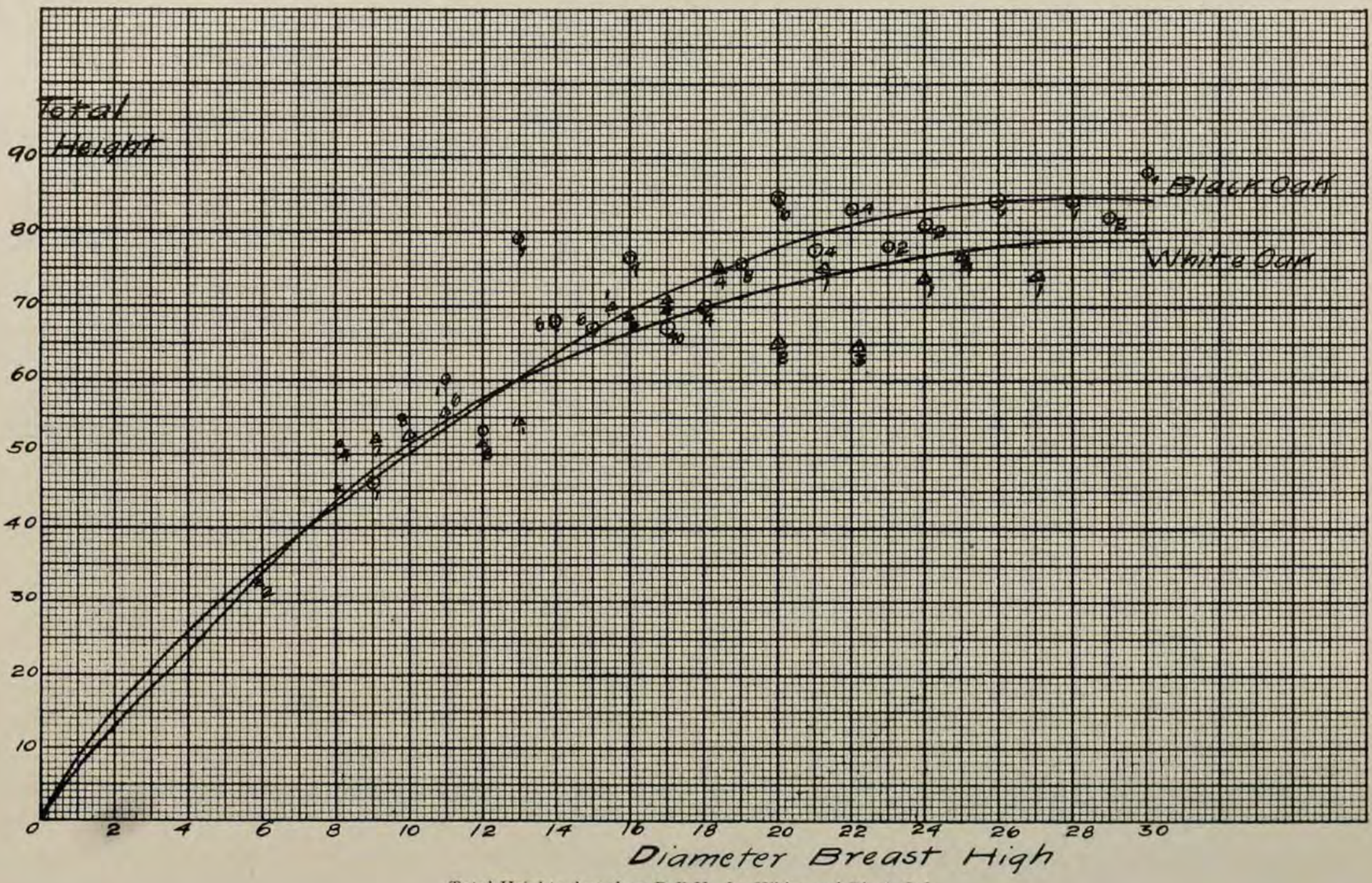

Total Heights, based on D.B.H., for White and Black Oak. 
GRAPH II

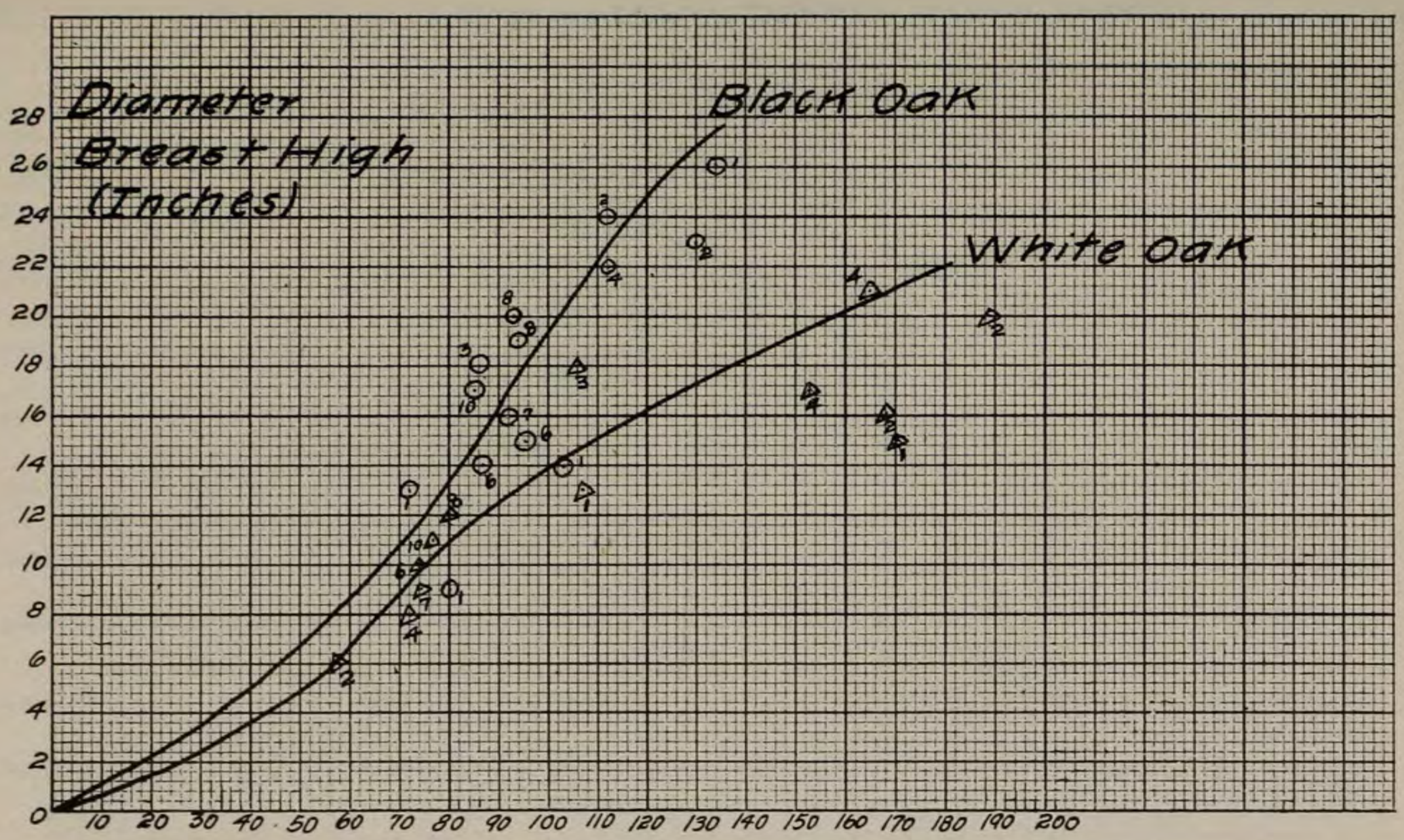

age on stump (Years)

Diameter Growth outside Bark at D.B.H. for White and Black Oak. 
GRAPH III

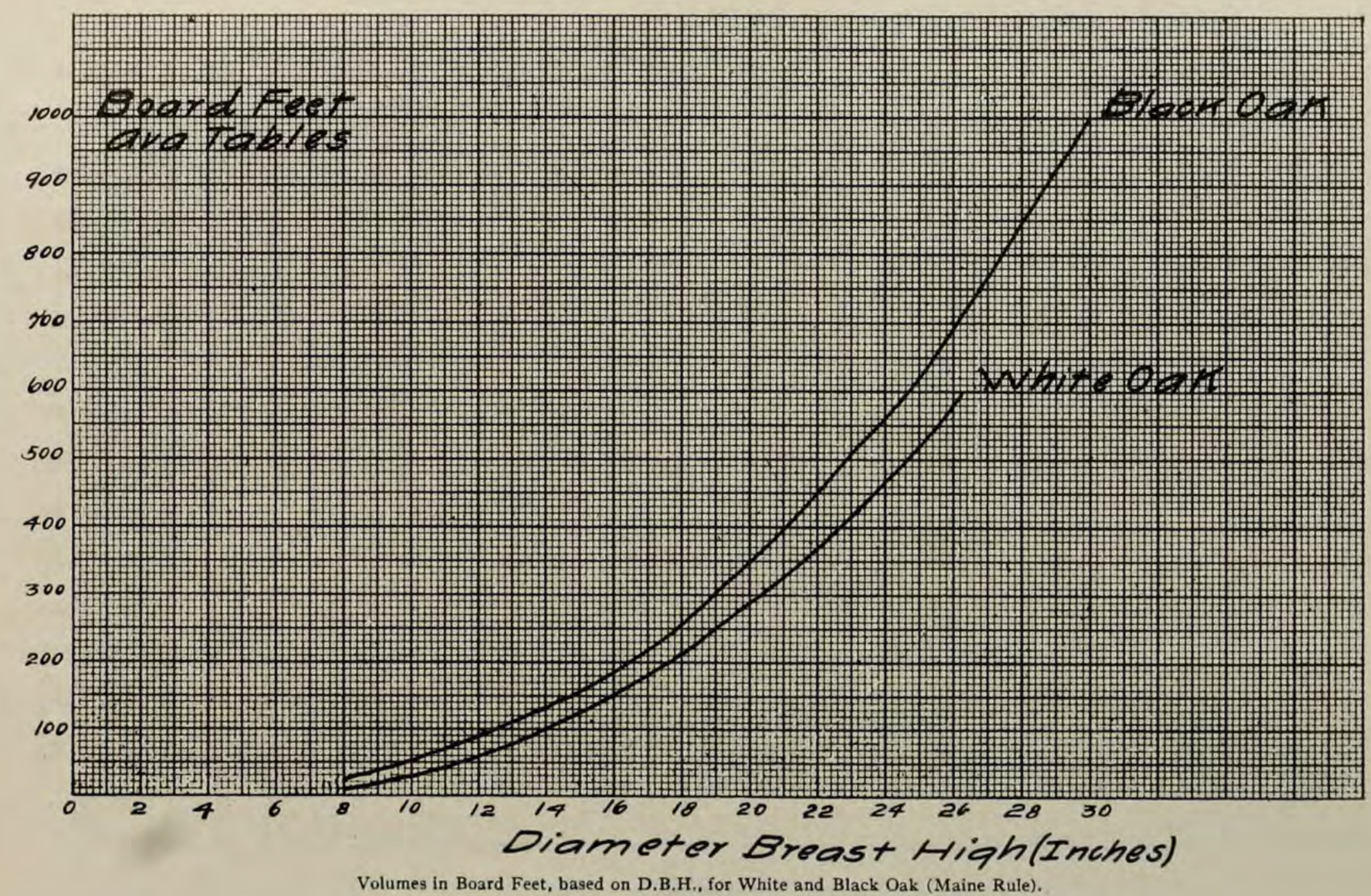


GRAPH IV

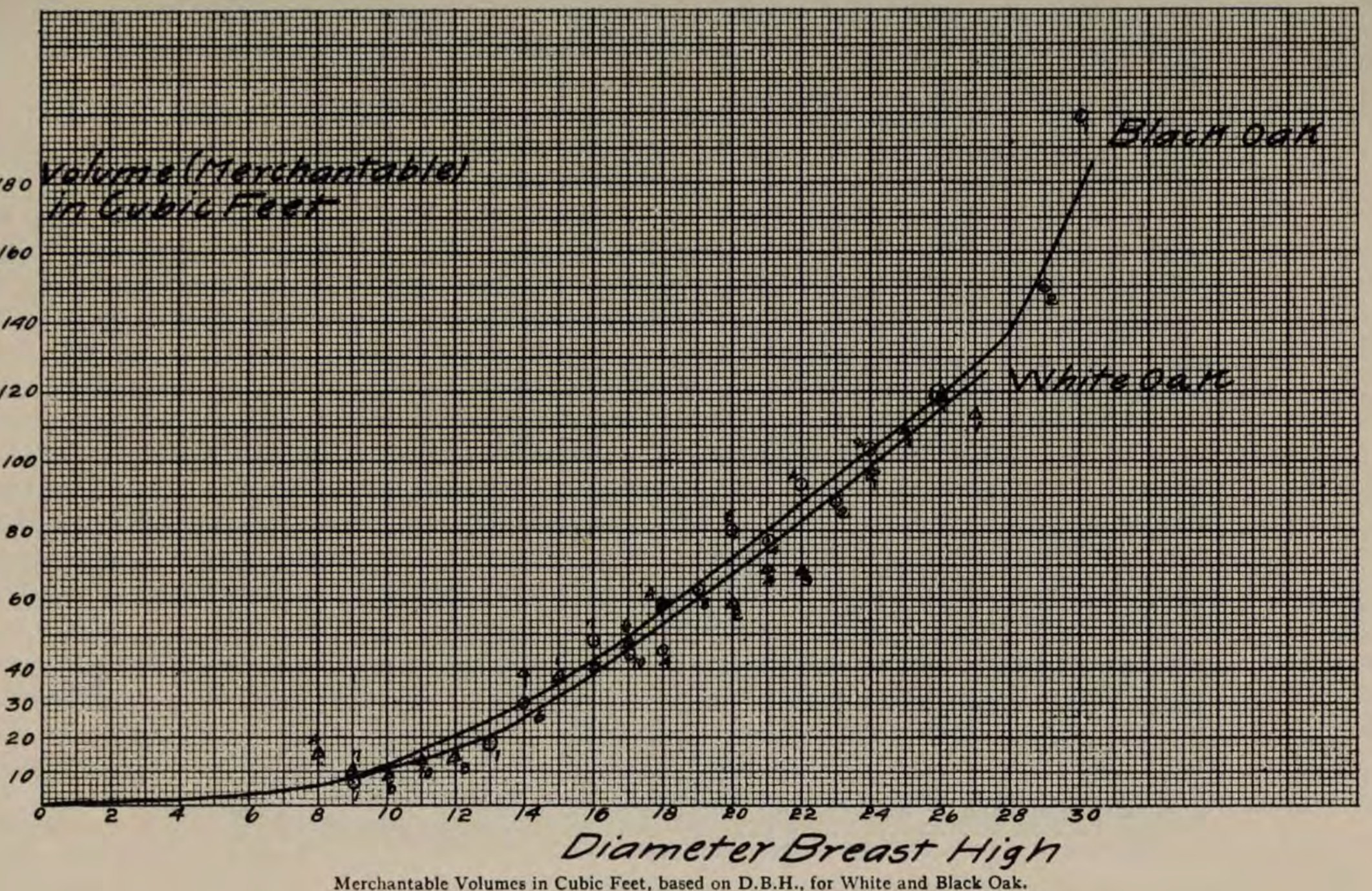


GRAPH V

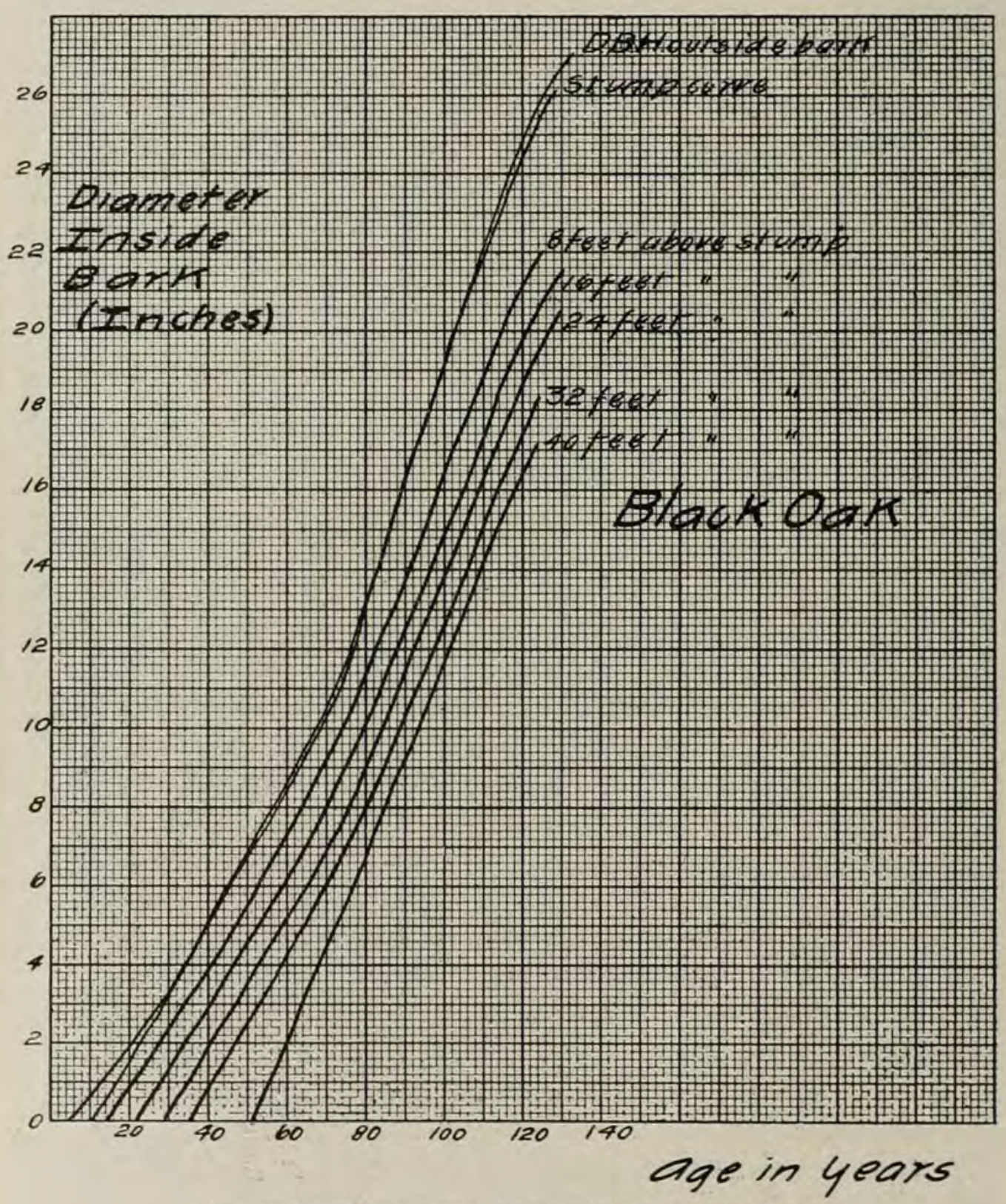

Diameter Growth inside Bark for Black Oak at different Heights. 
GRAPH VI

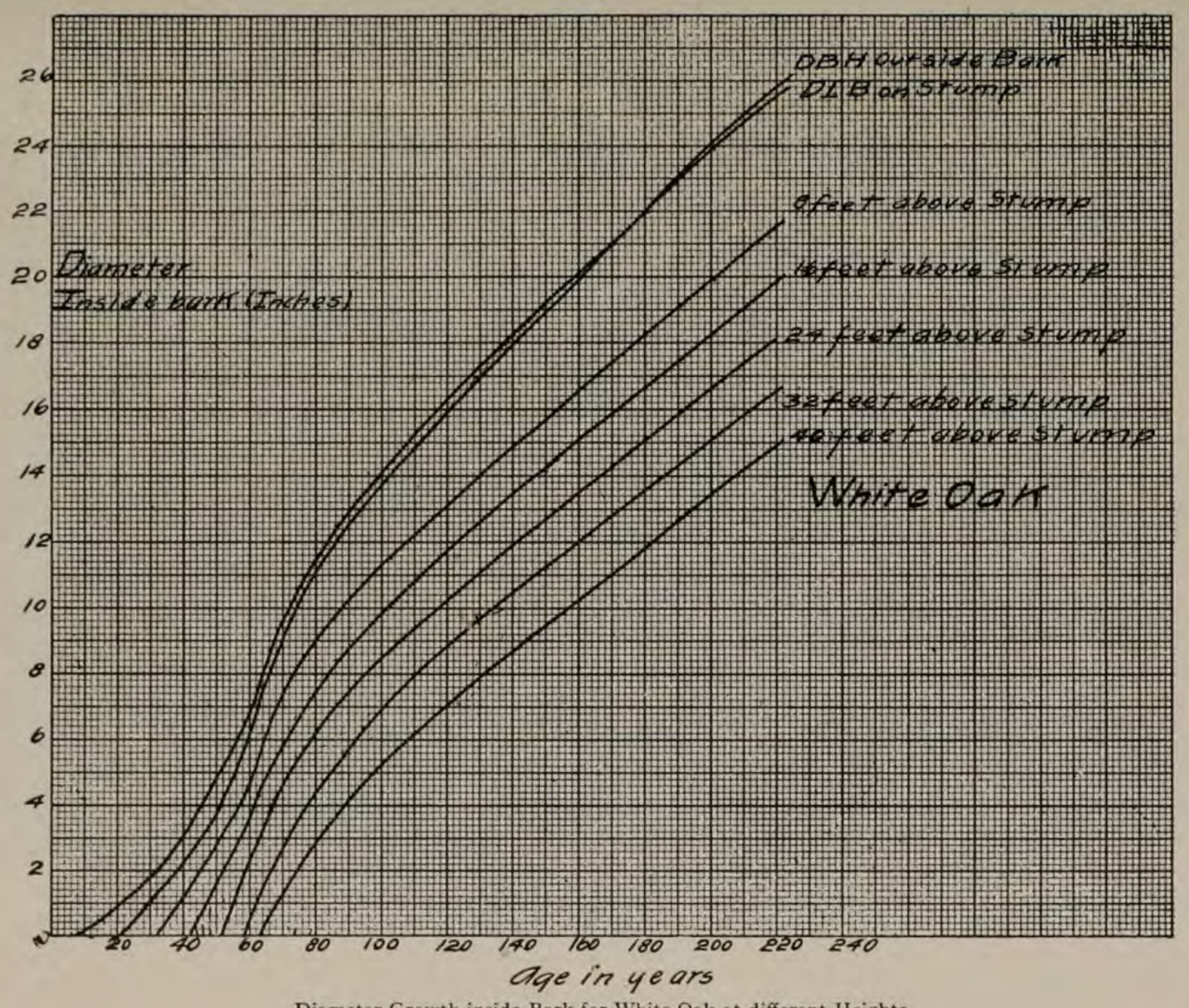

Diameter Growth inside Bark for Whitc Oak at different Heights. 


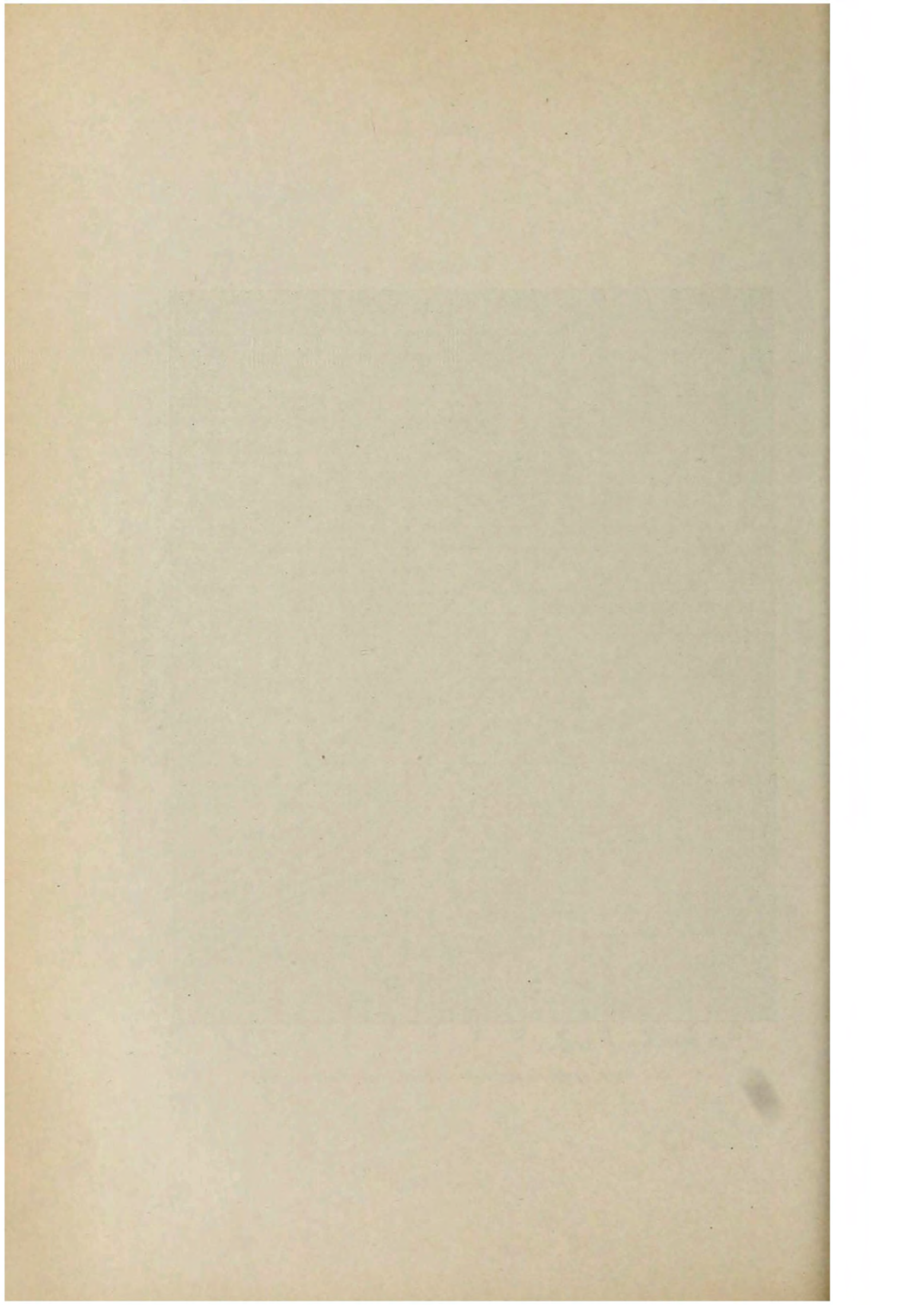


Plate LXXIV

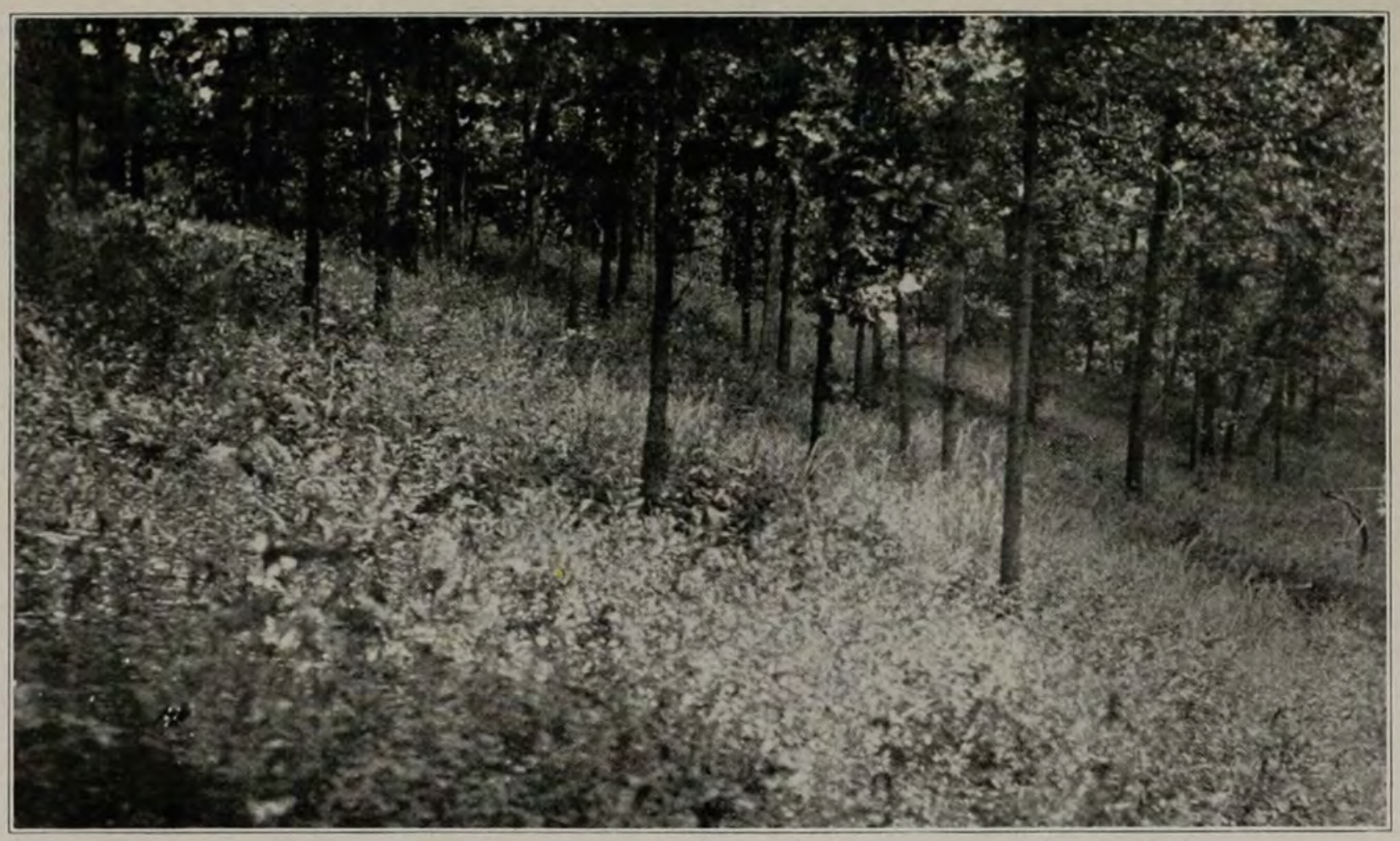

Dry oak-hickory forest, Clear Creek region, Jonesboro quadrangle. The dense growth of grass in the openings means that there is too much light, and it makes fire protection difficult. 
Plate LXXV

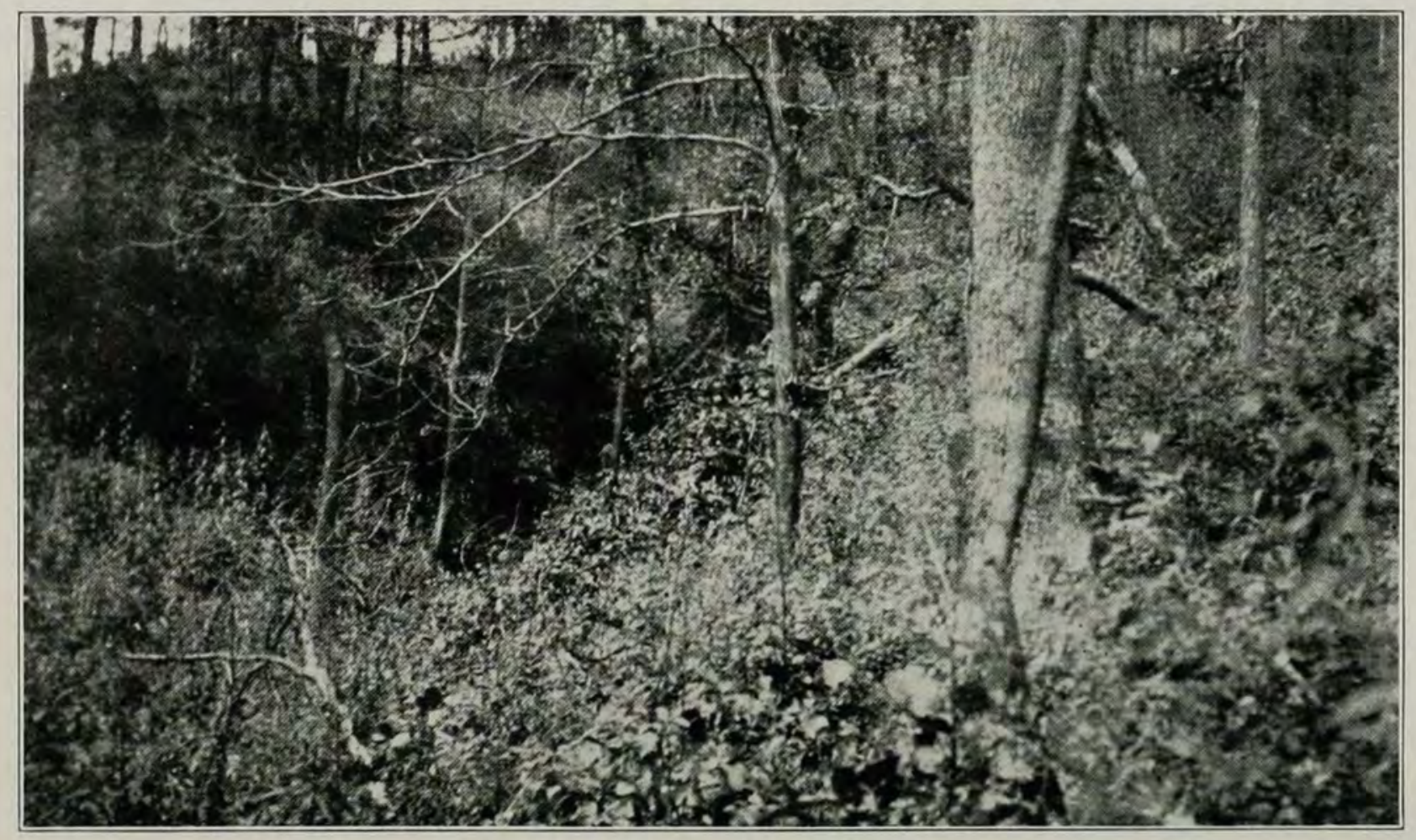

Cut-over land in the Caney Creek region, Jonesboro quadrangle, Union county. The former stand was made up ot white oak, beech, and tulip-tree. Notice the rank growth of weeds which greatly increases the liability to fire. 
Plate LXXVI

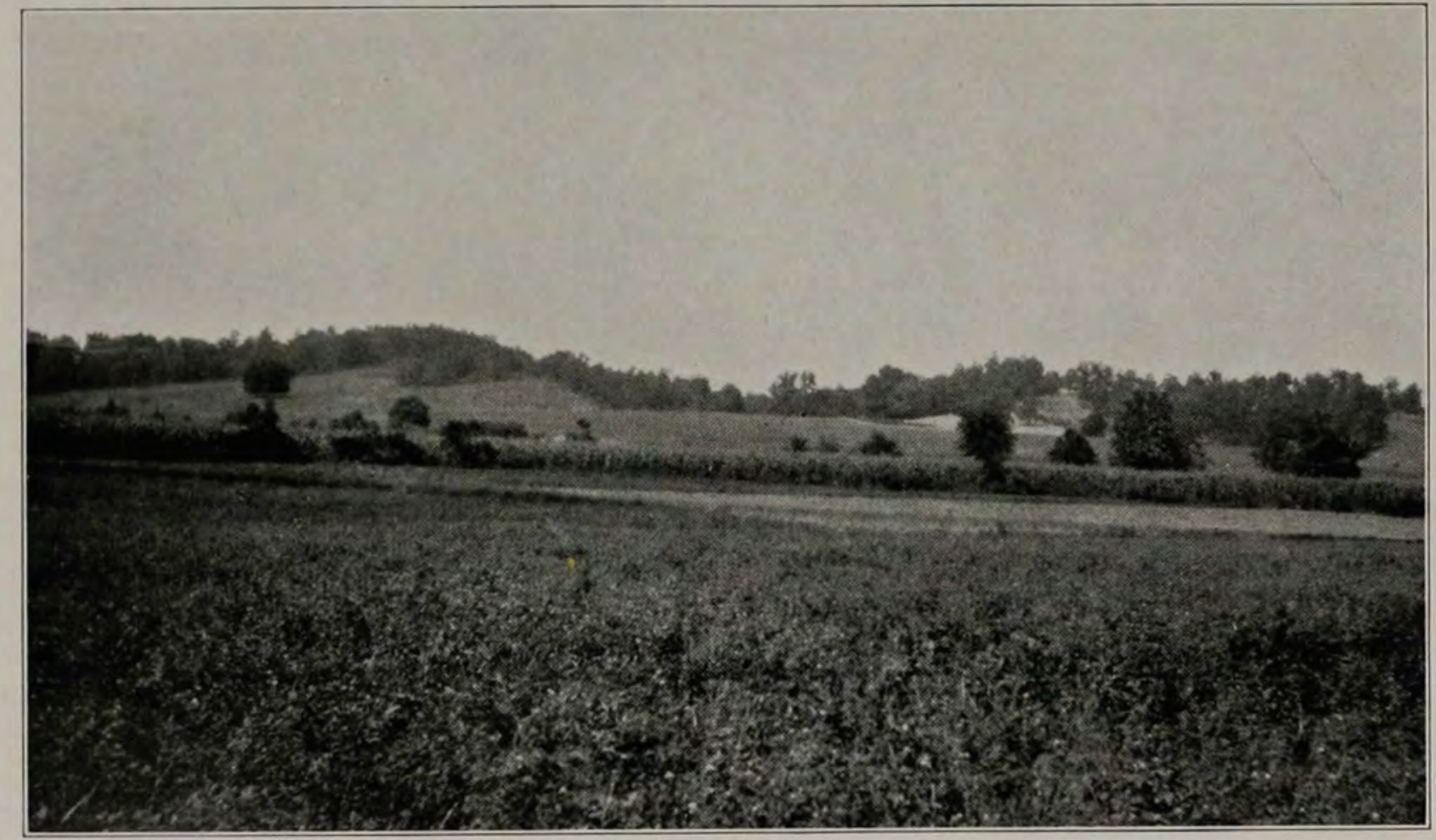

Narrow valley in Alexander county at the southern end of Jonesboro quadrangle, showing timber on the hills. 
Plate LXXViI

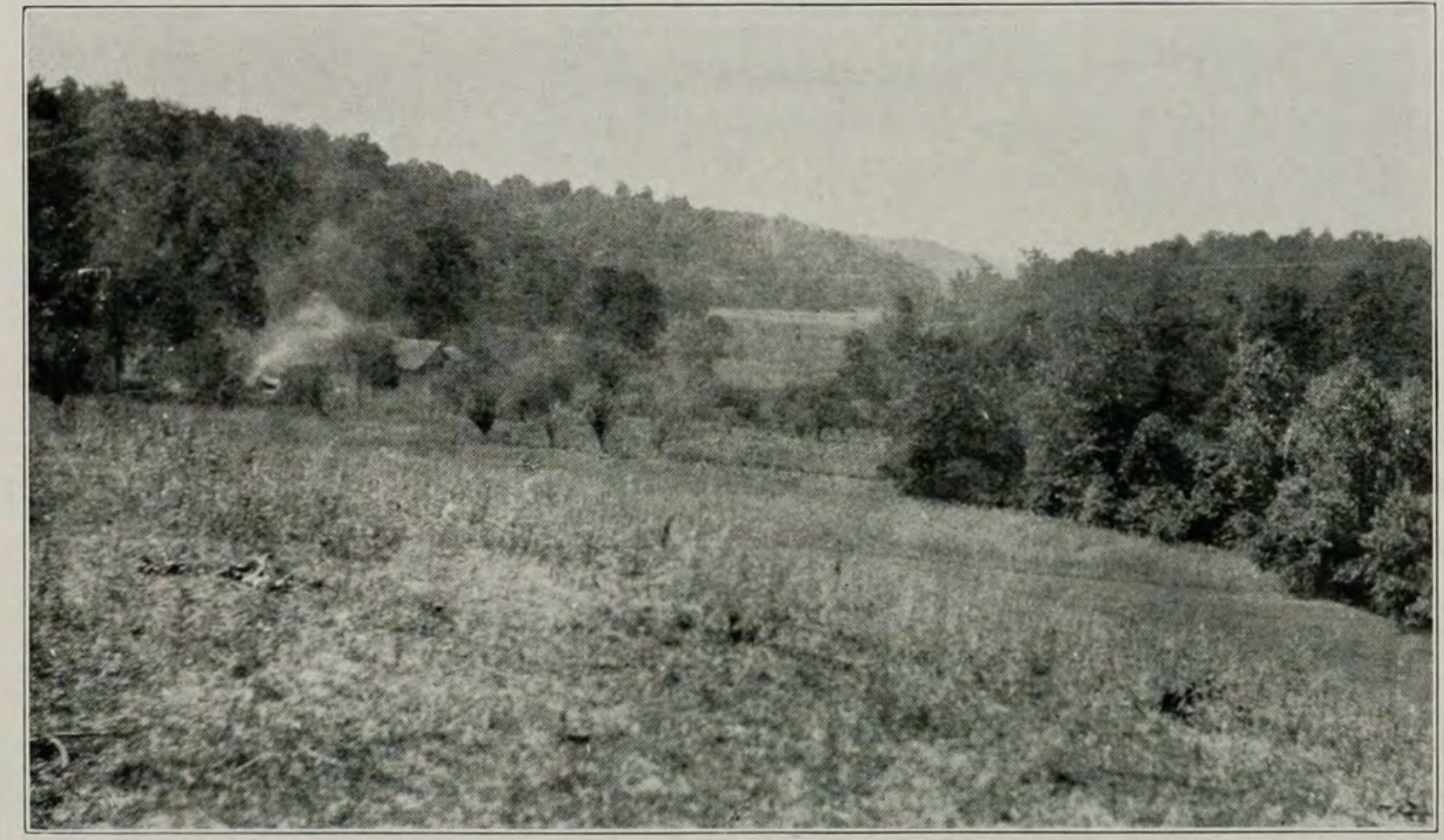

The valley of Caney Creek, Union county, northern edge of Jonesboro quadrangle. 


\section{Piate LXXVIII}

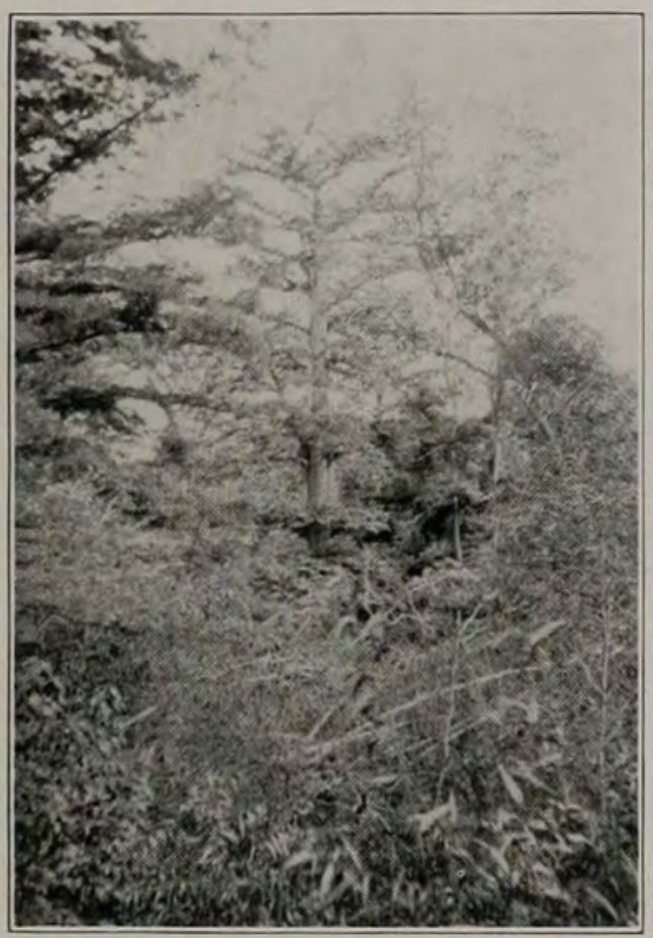

Cypress swamp.

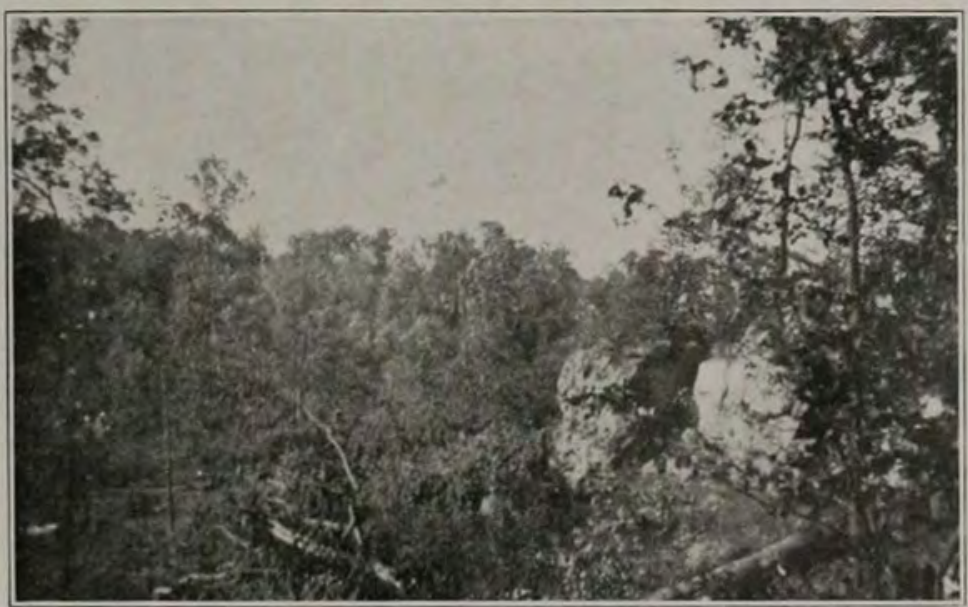

Limestone outcrop, Ava, Jackson county. 
Plate LXXIX

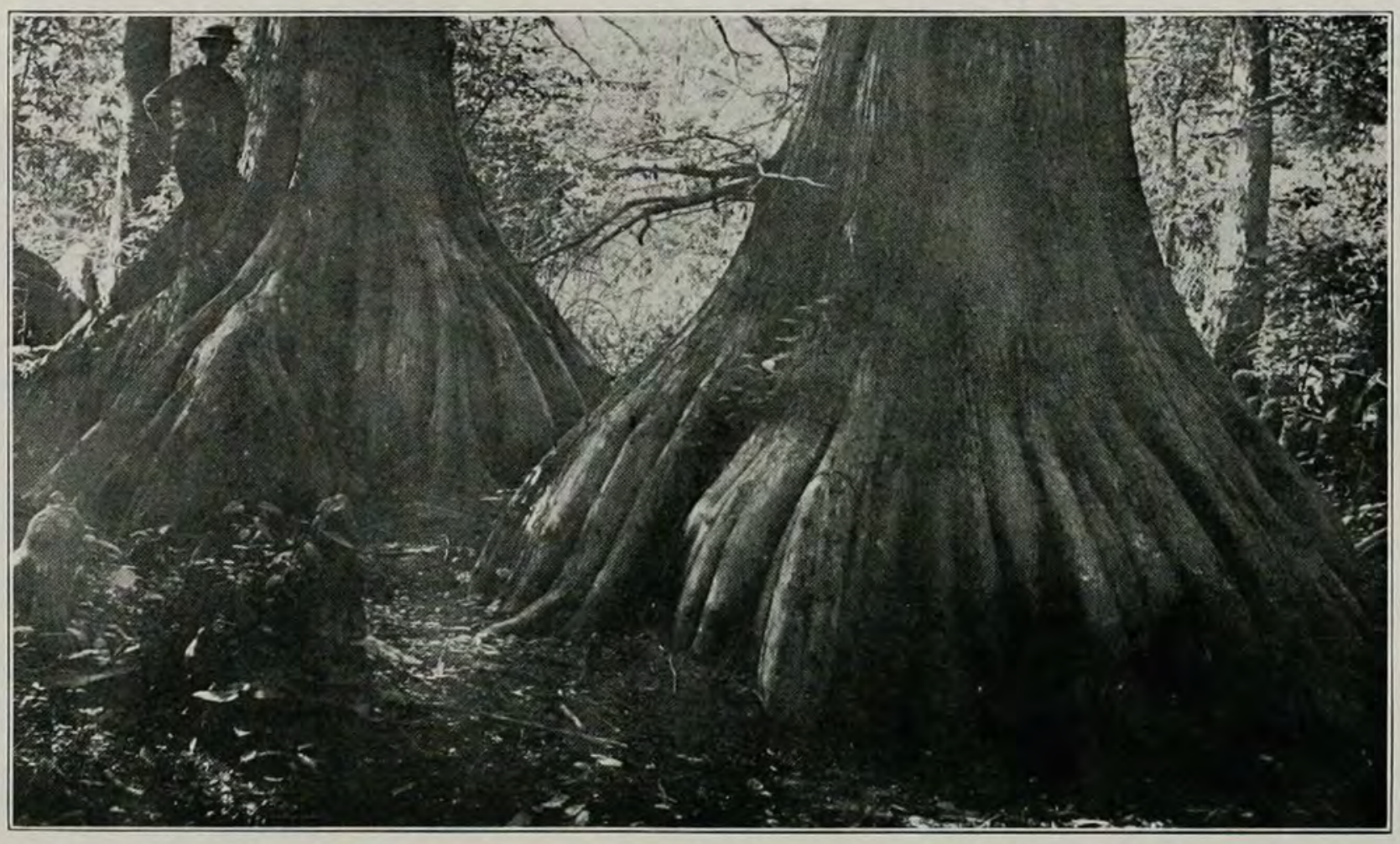

Bald cypress trees showing swollen bases, and three cypress "knees" in the left foreground. 


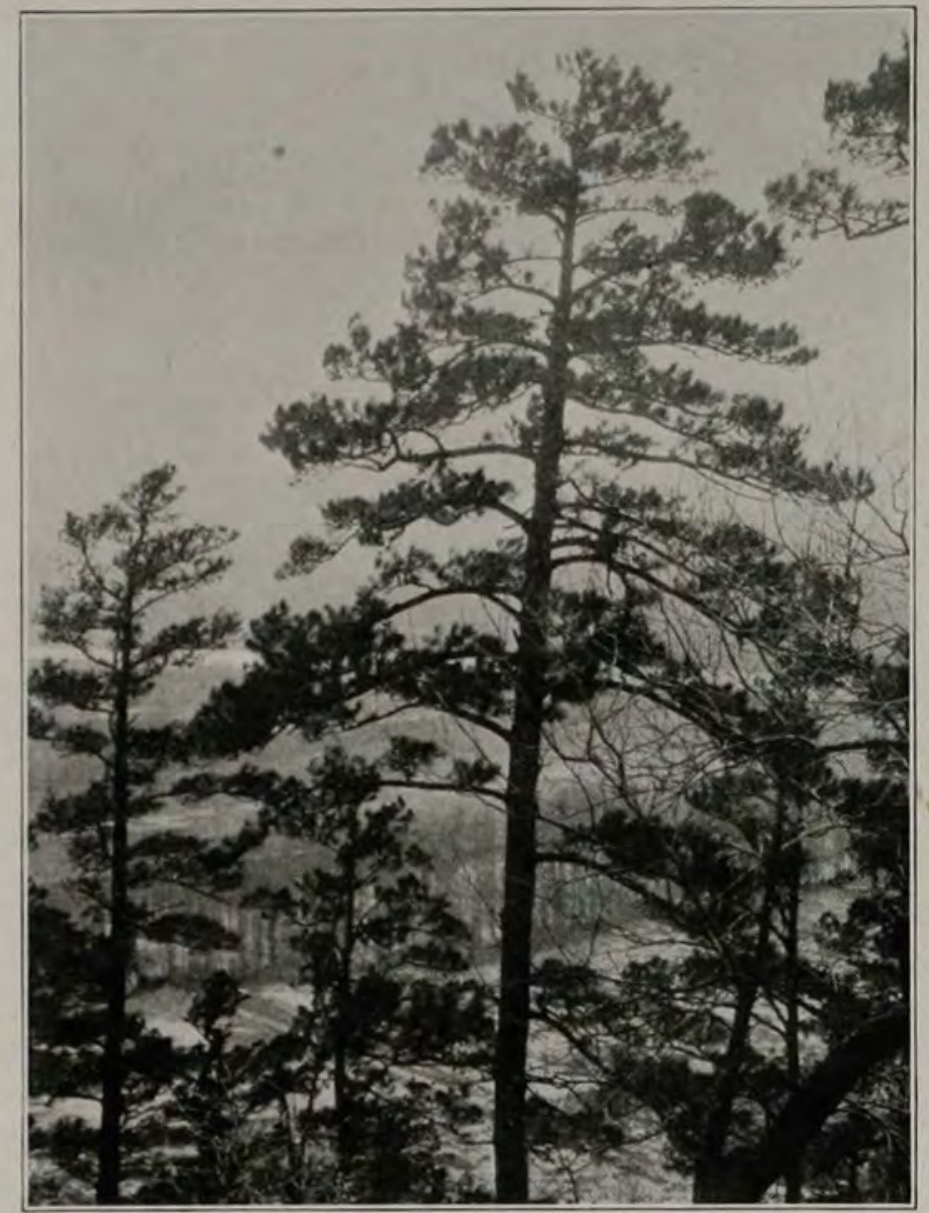

Shortleaf pine at Wolf Lake, Union county, overlooking the Photo by Paul J. Sedgwick.

\section{Plate LXXX}

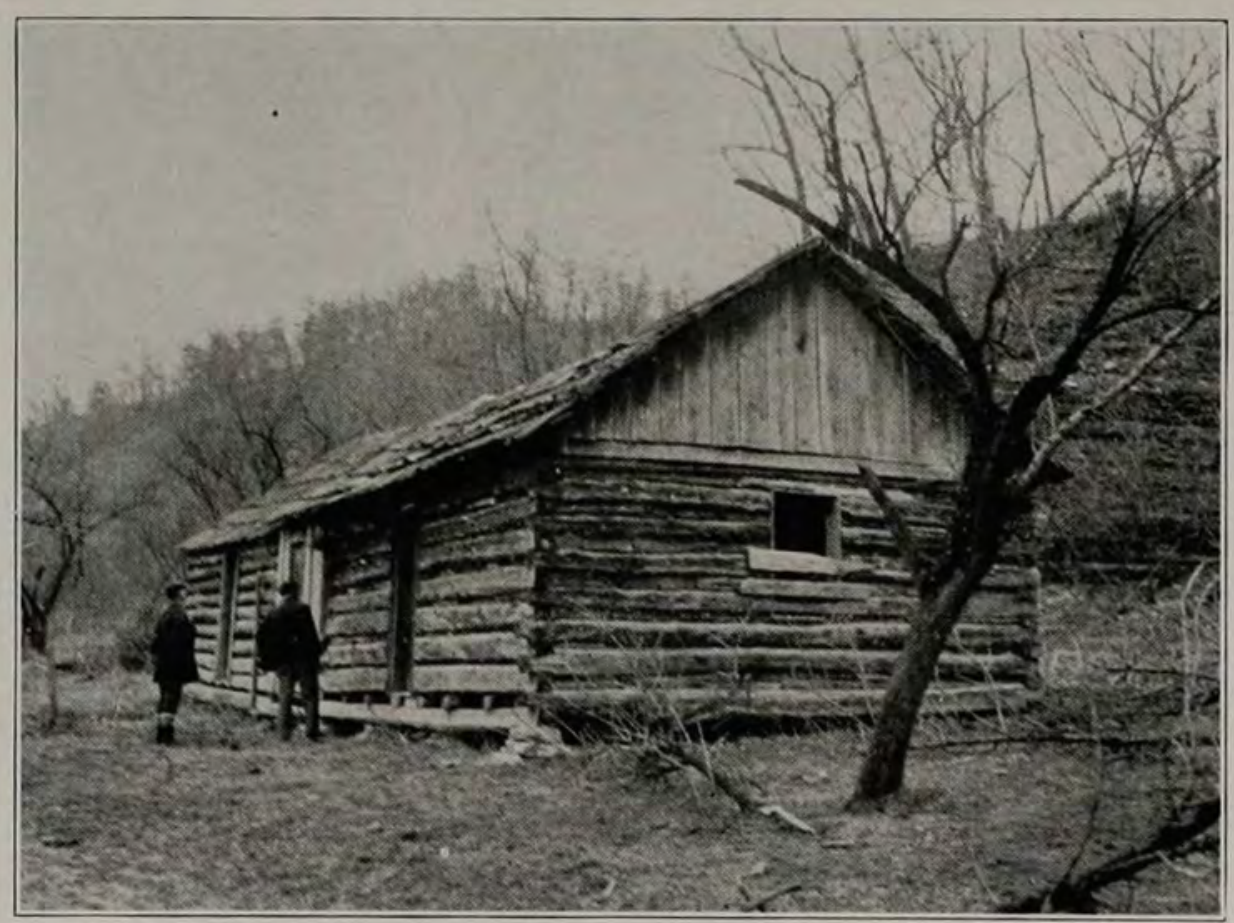
Old house at Wolf Lake, Union county, built of shortleaf pine logs.
Photo by Paul J. Sedgwick. 
Plate LXXXI

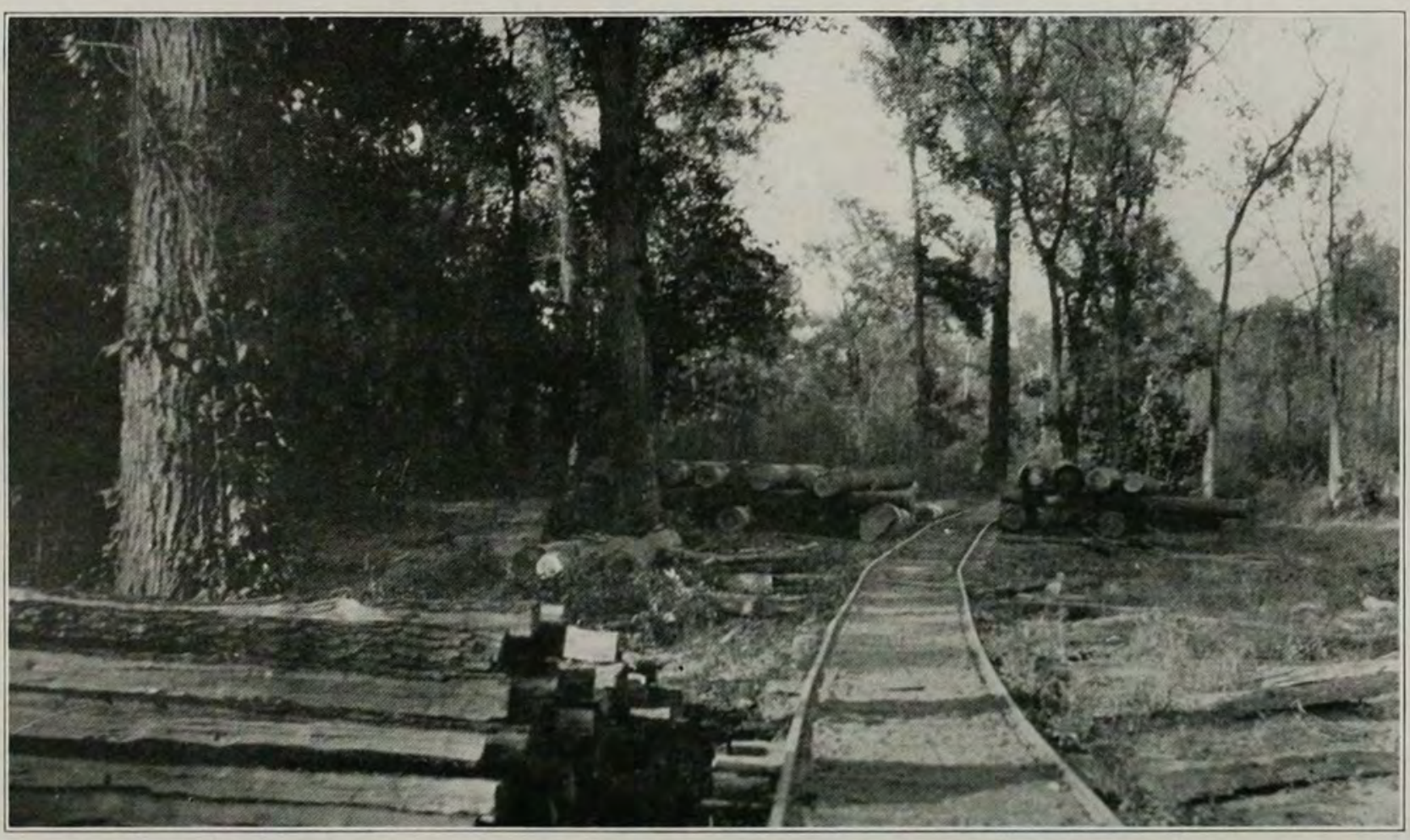

Skidway at Indian Creek, near Murphysboro, Jackson county, where hardwood logs are loaded on tramways. 
Plate LXXXII

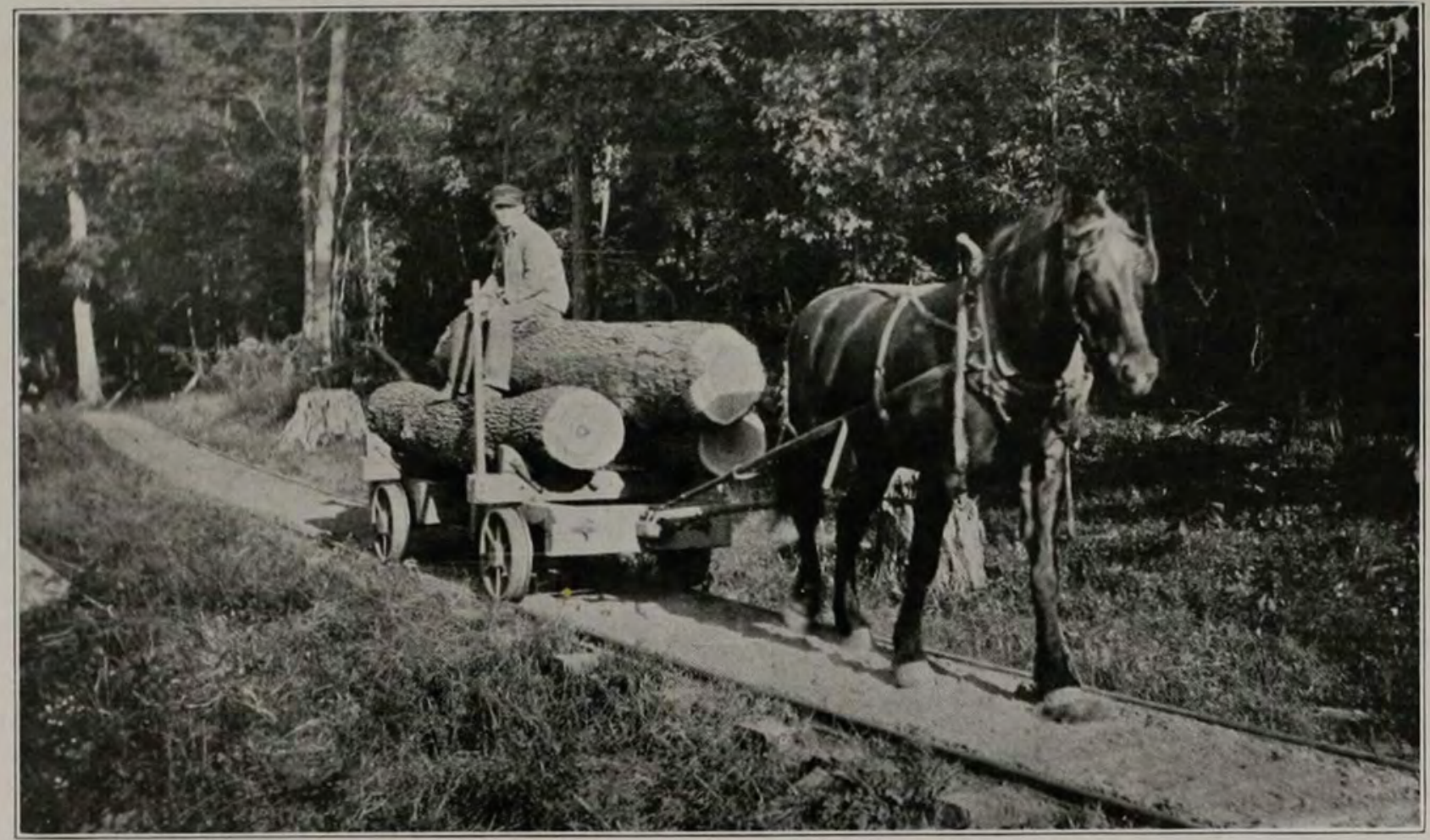

Logs going to the mill on a tramway, at Indian Creek, Murphysboro. 
Plate LXXXIII

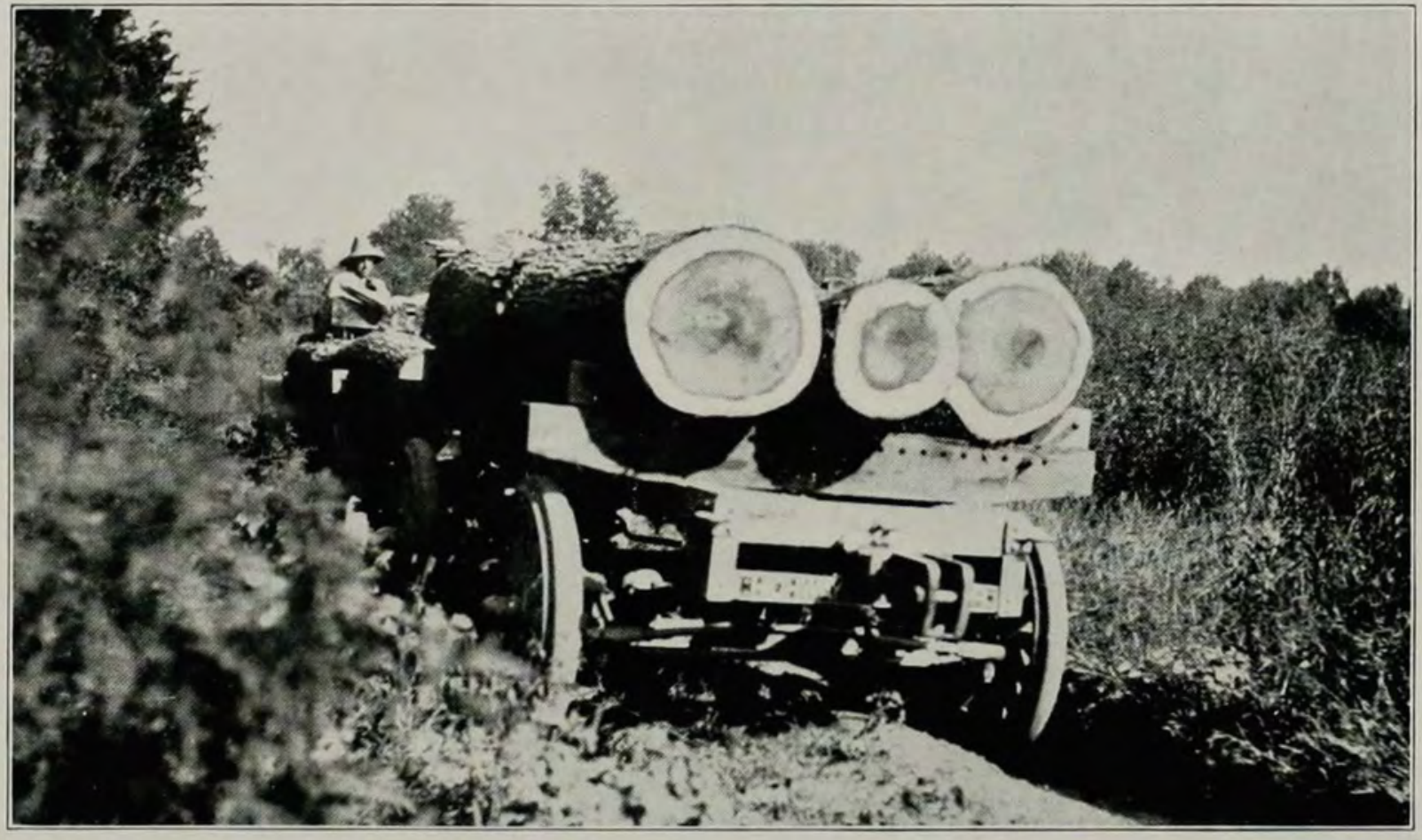

Hauling logs by motor-truck from bottomlands to mill at Ware, Union county. 
Plate LXXXIV

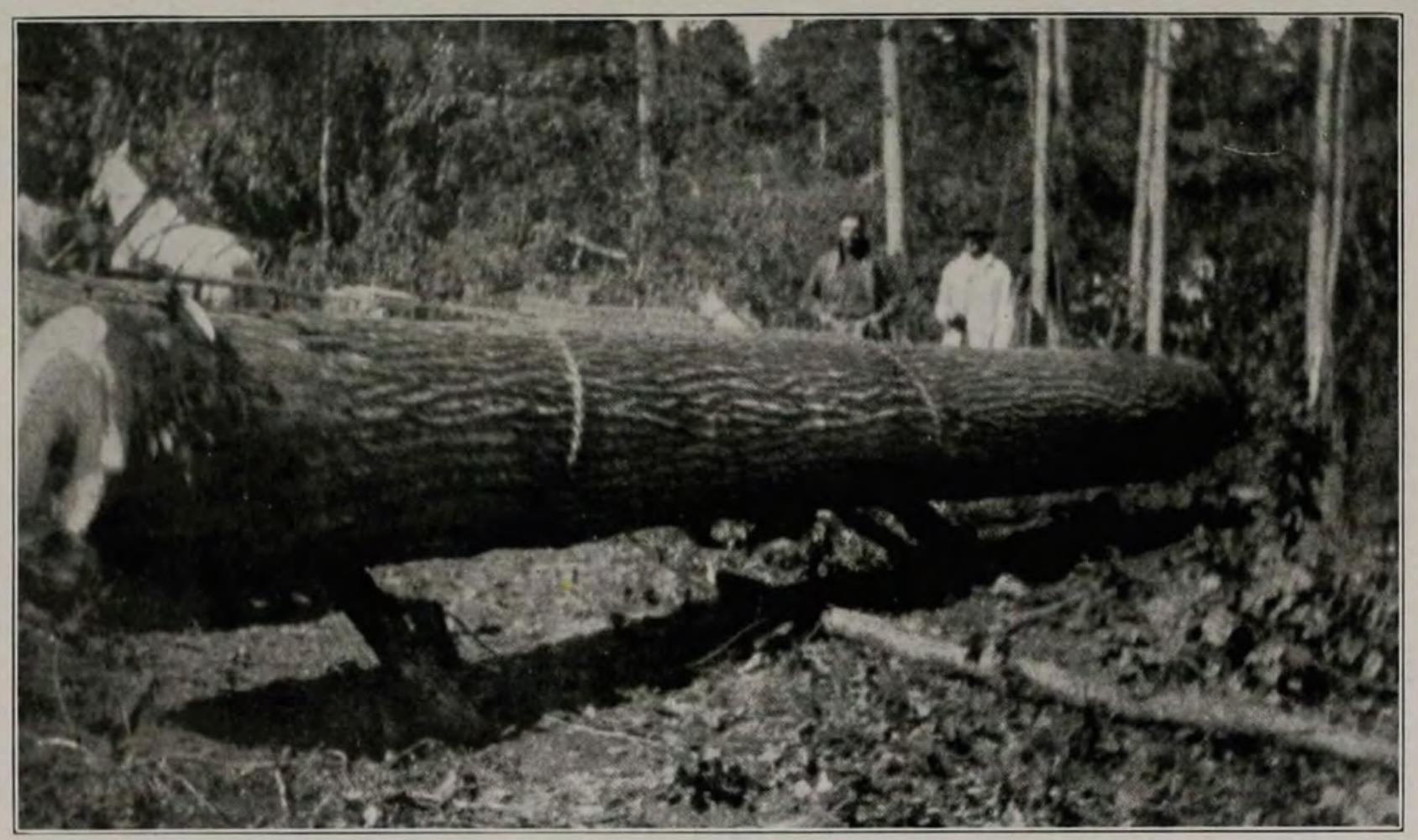

Tulip-tree, or yellow poplar, log being loaded on a log wagon near Ava, by the "cross-haul" method. It is a butt log 20 feet in log being ioaded on a log wagon near Ava, by the "cross-haul" mether
length, which will scale 500 board feet by the Doyle-Scribner rule. 
PLATE LXXXV

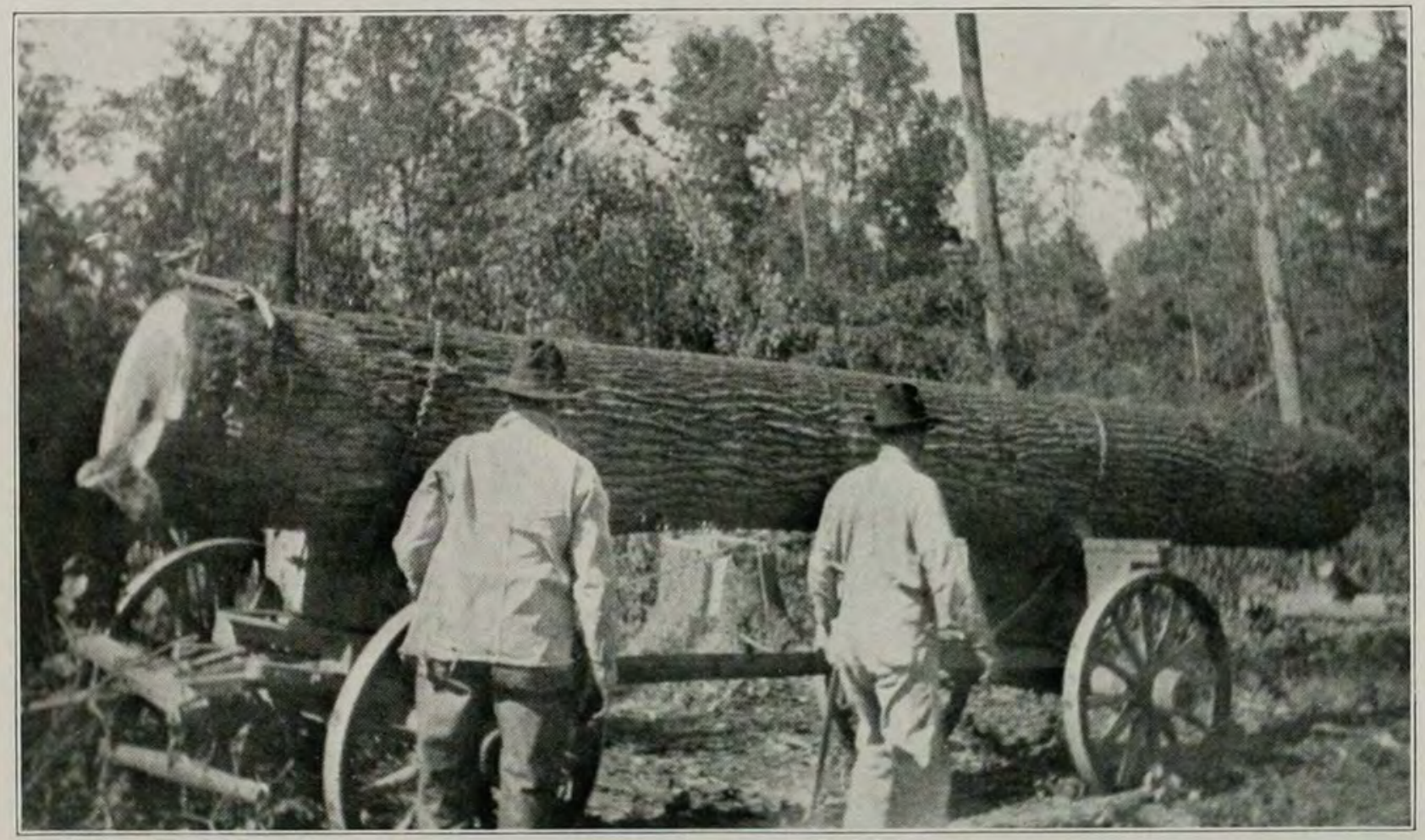

Butt $\log$ of a large tulip-tree, or yellow poplar, loaded on a log wagon, or "dray" ready for hauling to the mill at Ava. This log was 20 feet long and would scale 500 feet by the Doyle-Scribner rule. 
Plate LXXXVI

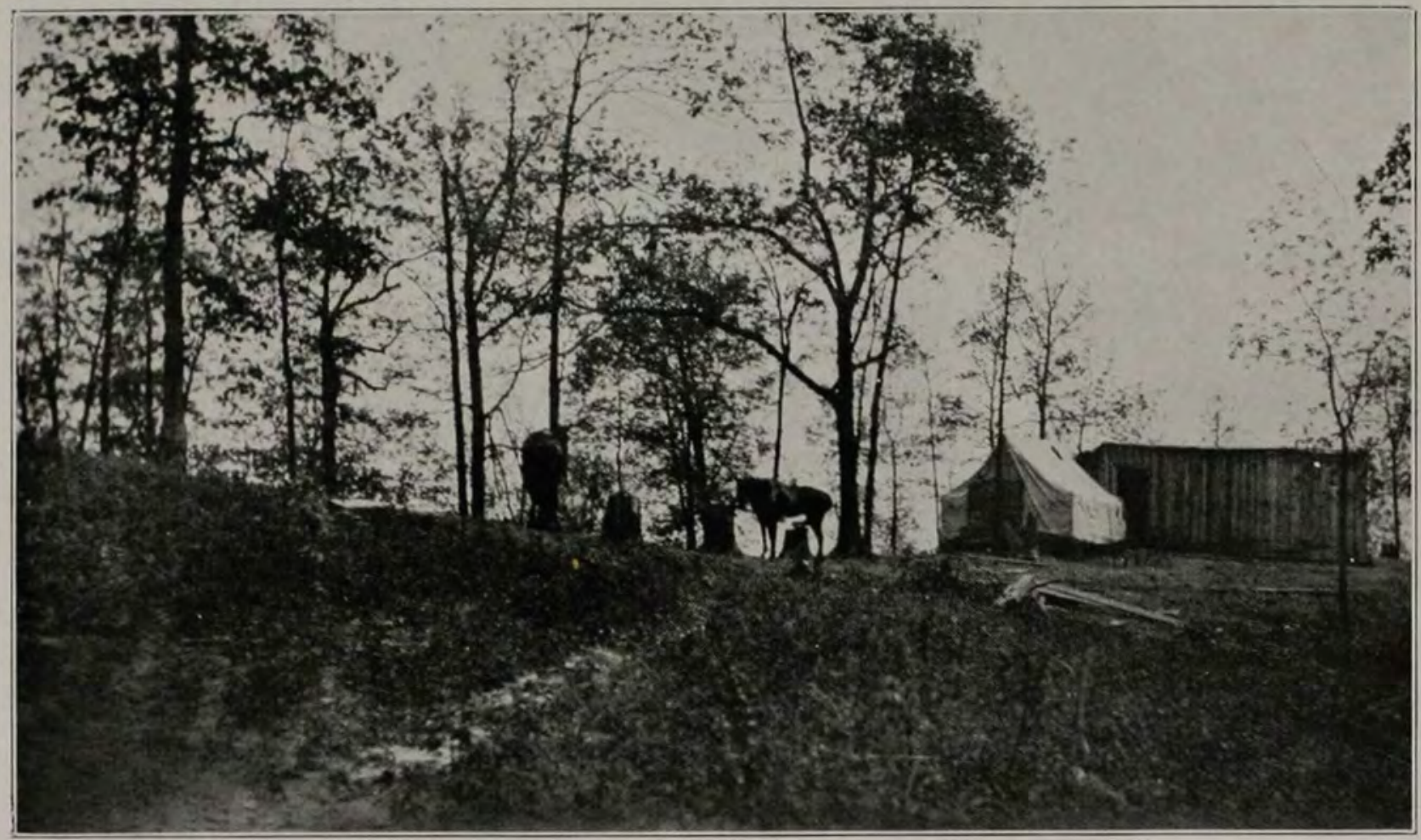

A "tie-hackers' camp" at Alto Pass, Union county. These men are usually financed by a tie contractor. 
Plate LXXXVII

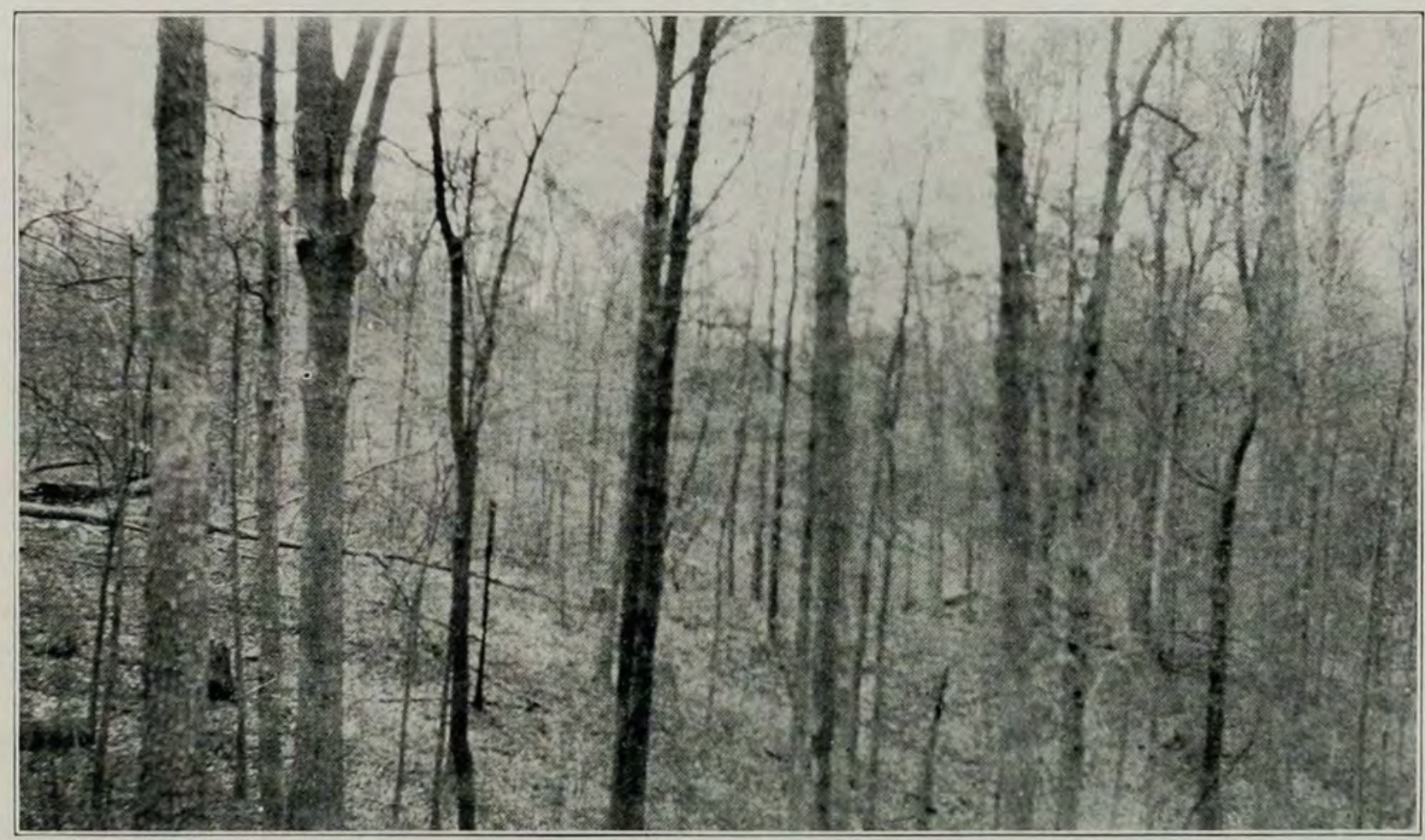

White oak and black oak timber which has been culled for ties. Notice that a fair stand of timber remains which it would pay to protect. Alto Pass, Union county. 
Plate LXXXVIII

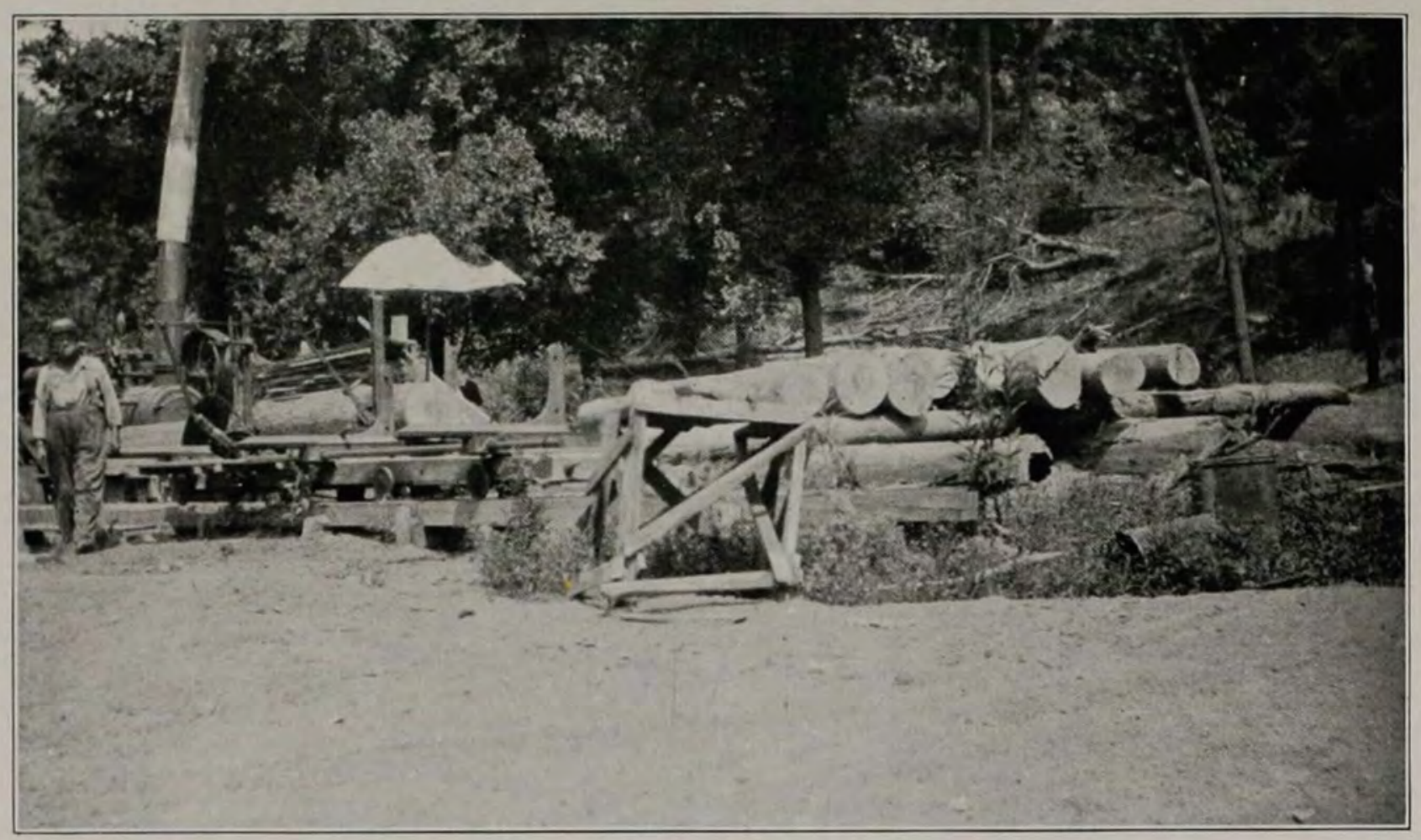

A small portable mill on the "Dug Hill" road, Union county, operated by S. A. Morse, who is seen sawing railroad ties from beech logs. 
Plate LXXXiX

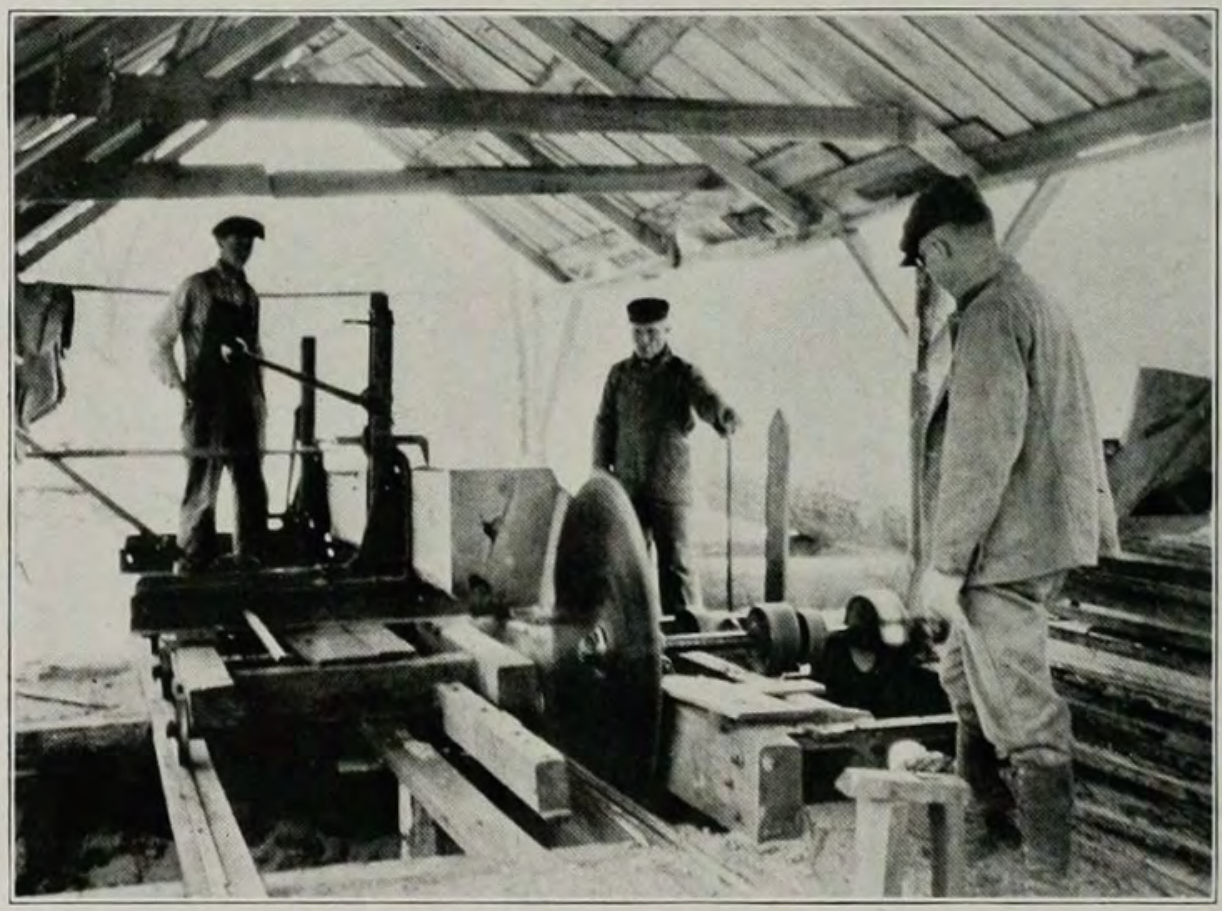

Small portable sawmill near Alto Pass, Union county. Photo by Paul J. Sedgwick. 
Plate XC

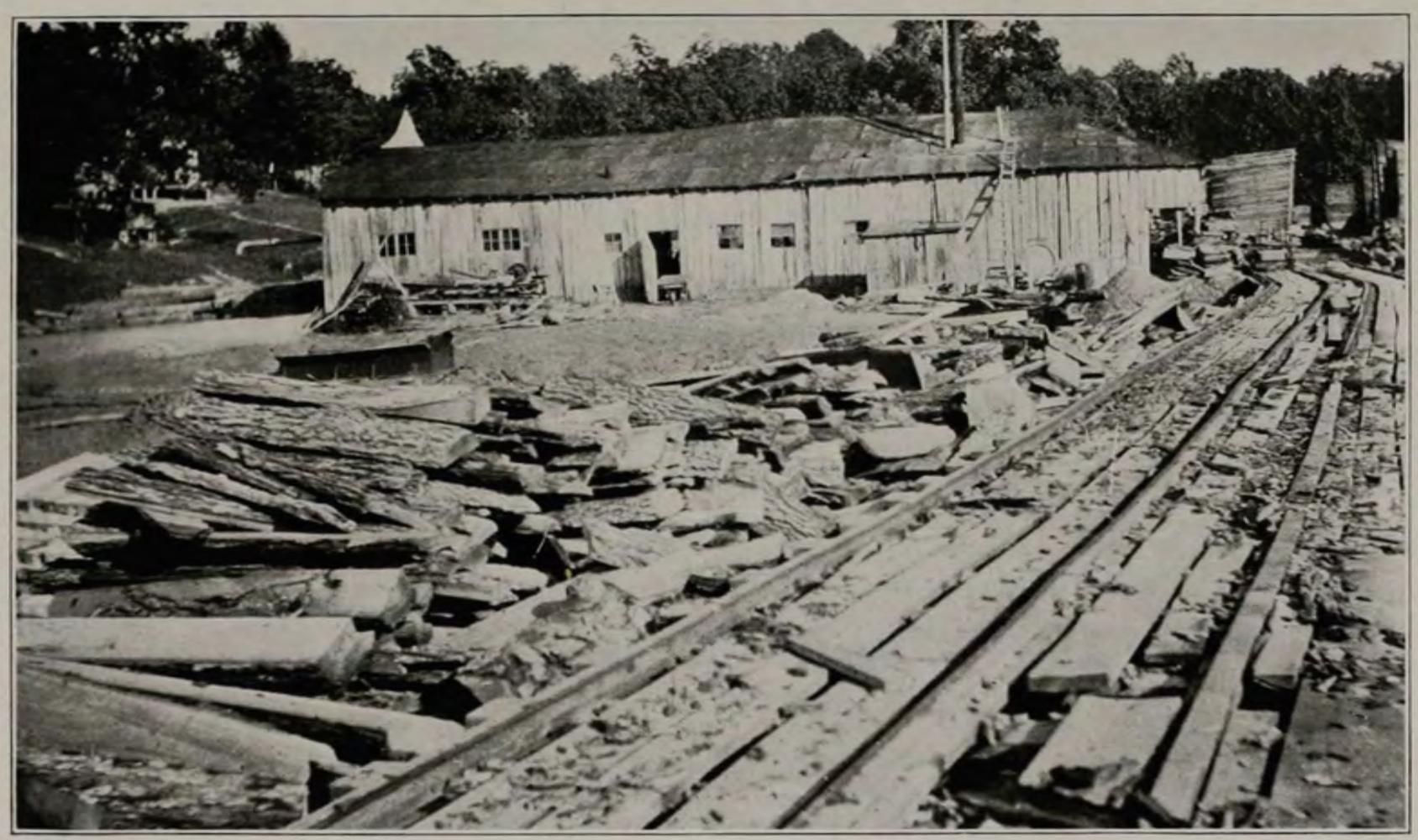

Larger, stationary, sawmill near Indian Creek, Murphysboro, Jackson county. 
Plate XCI

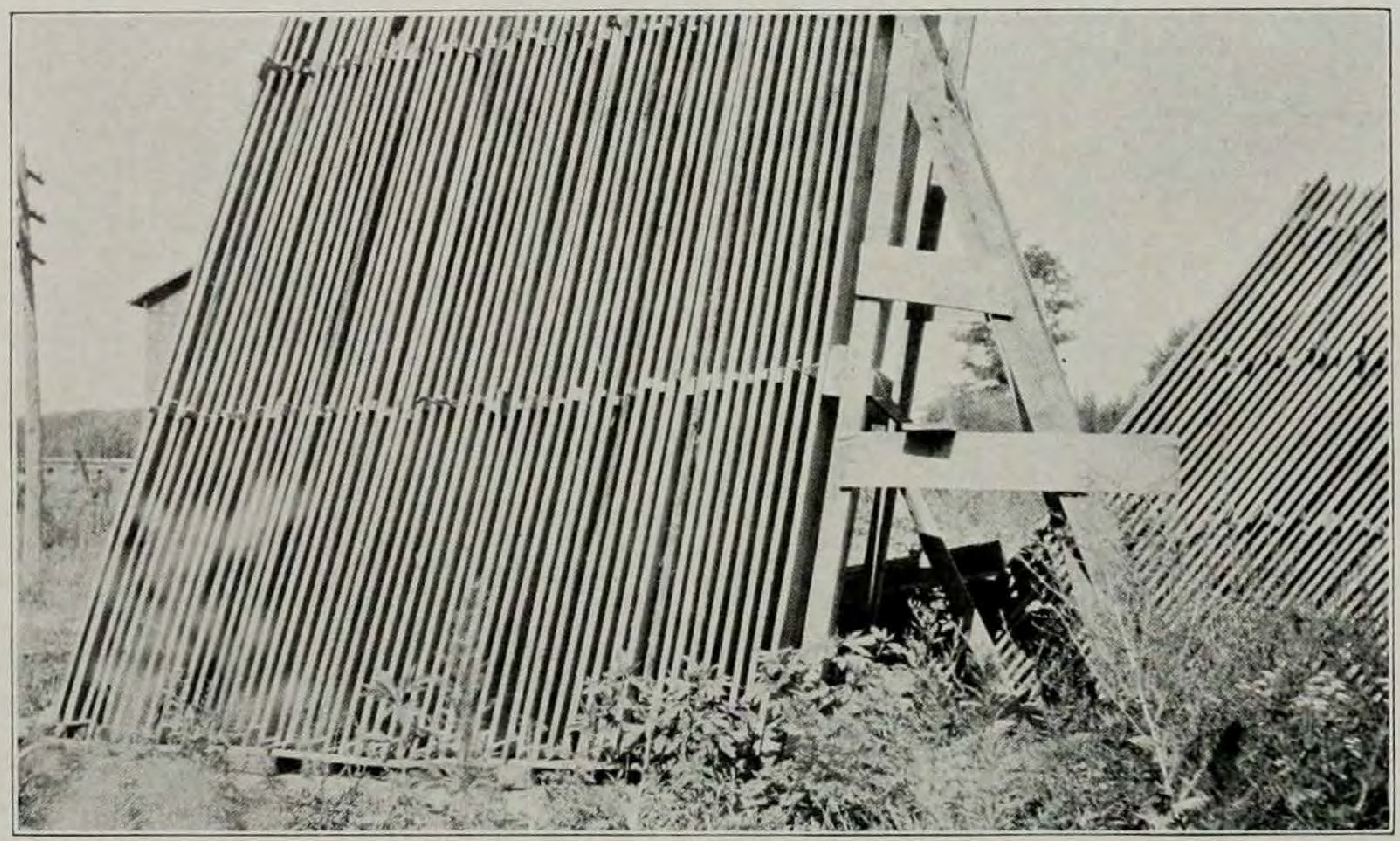

Sawed lumber piled on end, Jonesboro, Union county. 


\section{Plate XCII}

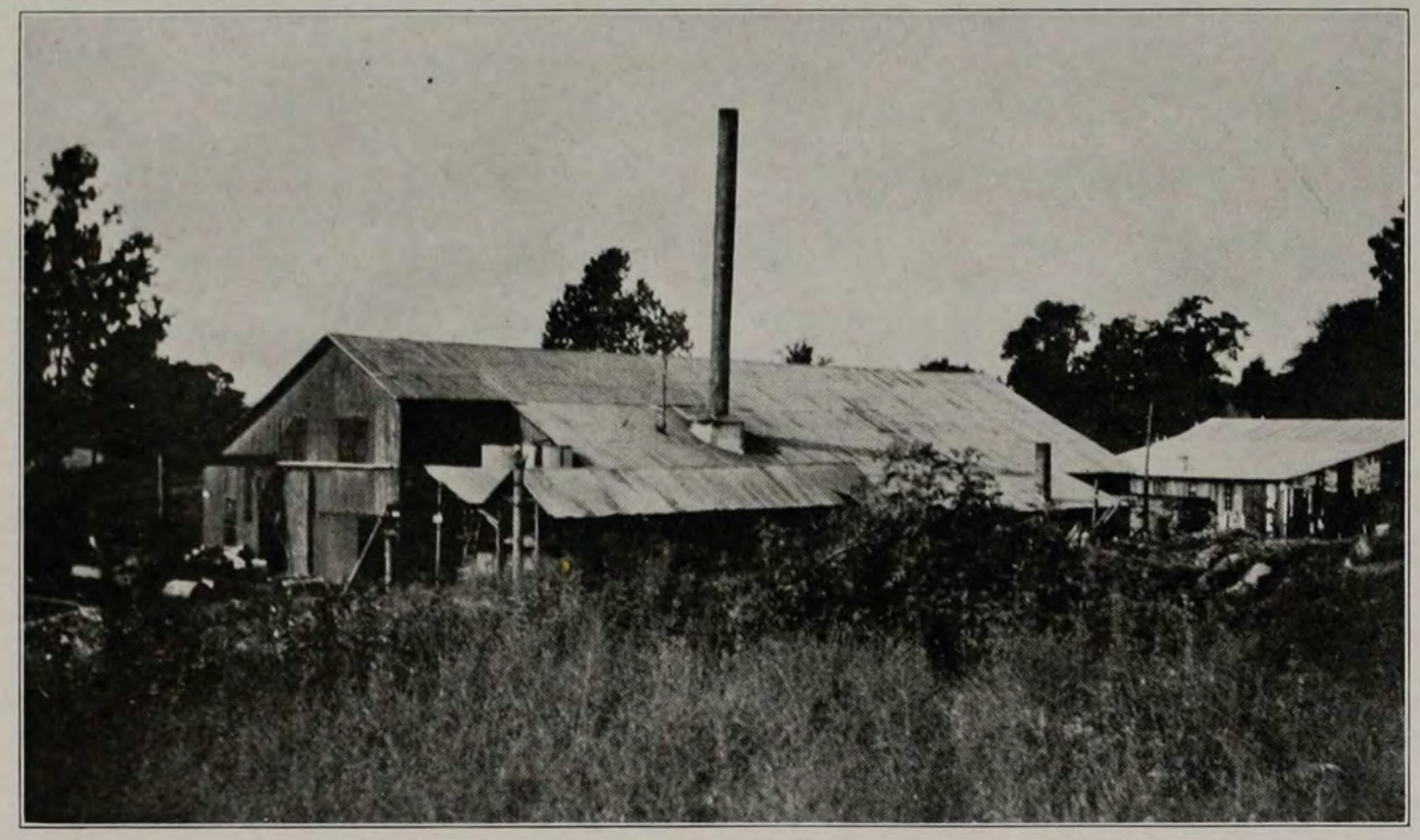

Veneer mill of the Fruit-Growers' Package Company, Jonesboro, Union county. 
Plate XCIII

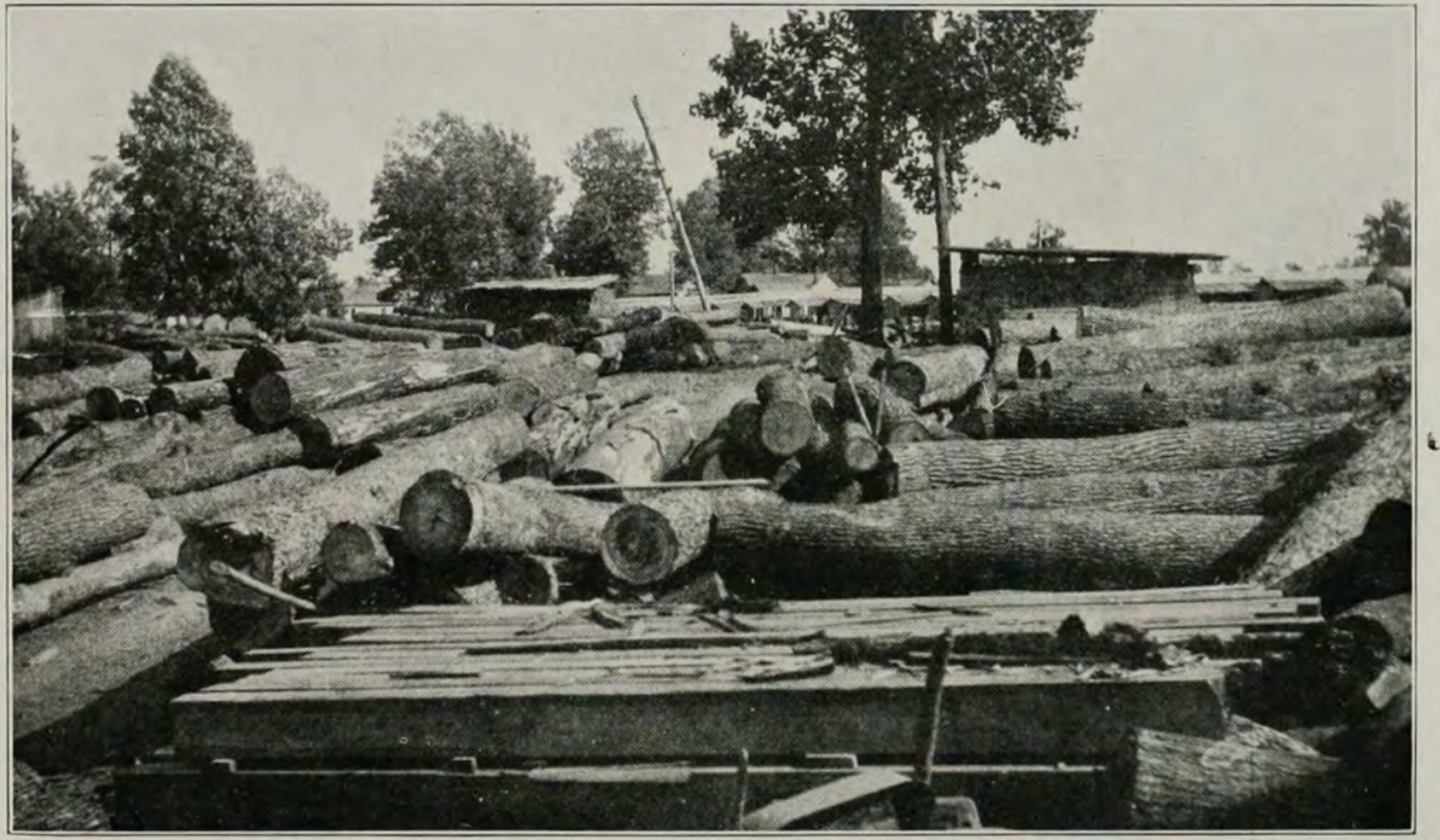

Hardwood logs at a veneer plant ready to be cut up into bolts. Most of these come from bottomlands. 
Plate XCIV

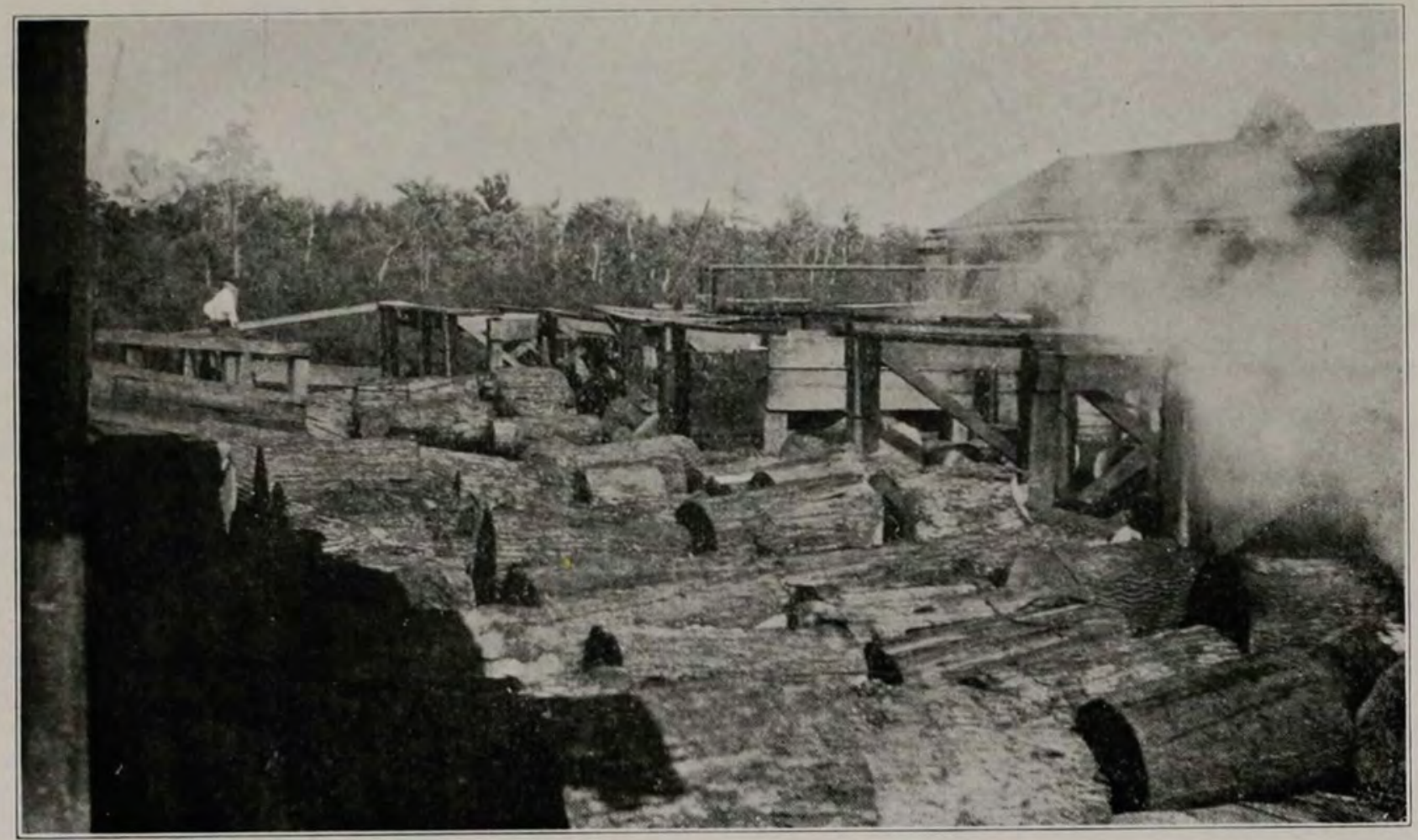

Veneer bolts from the cut-off saw ready to go to the steam boxes for softening before being taken to the rotary veneer-machines. 
Plate XCV

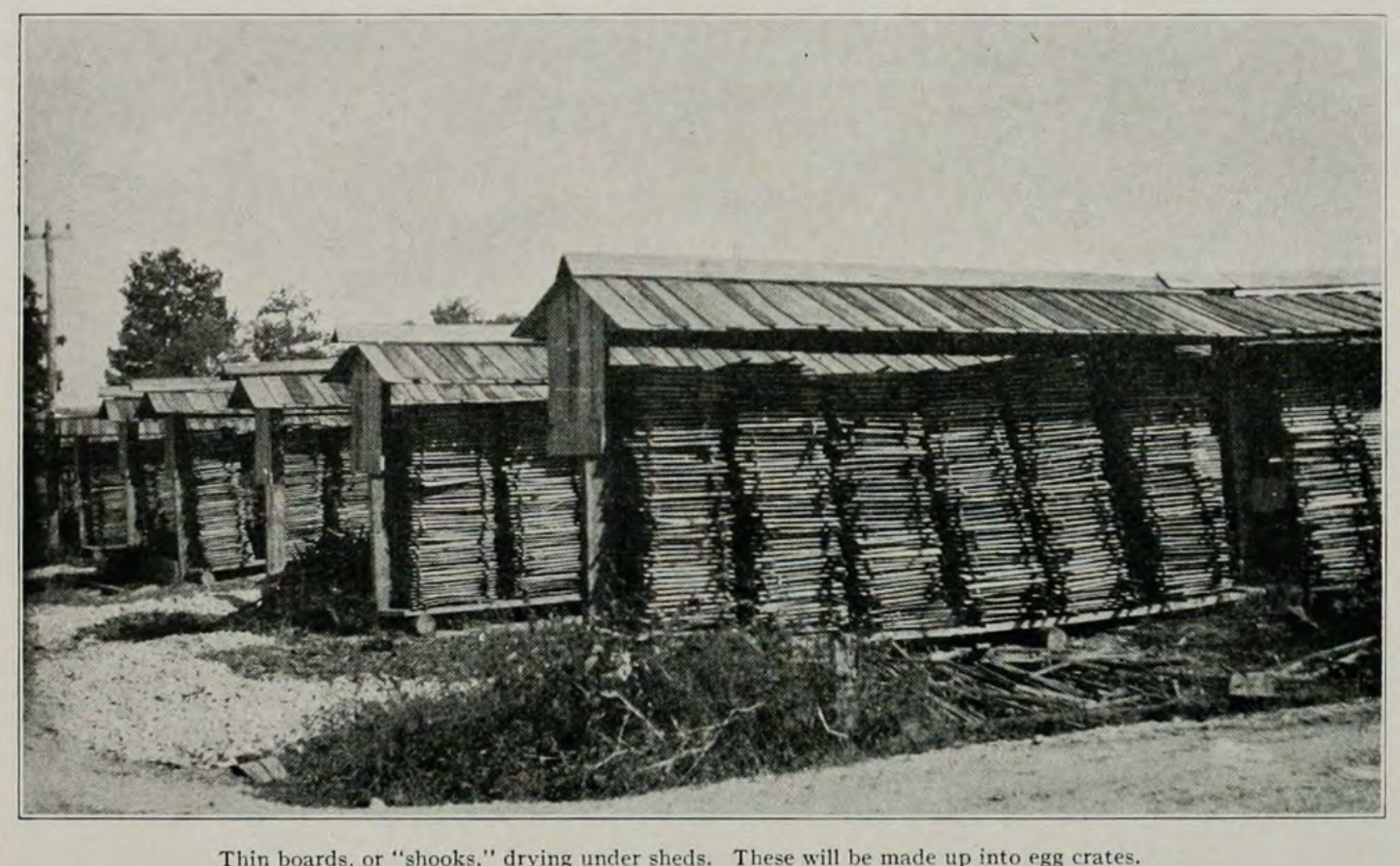

Thin boards, or "shooks," drying under sheds. These will be made up into egg crates. 
Plate XCVI

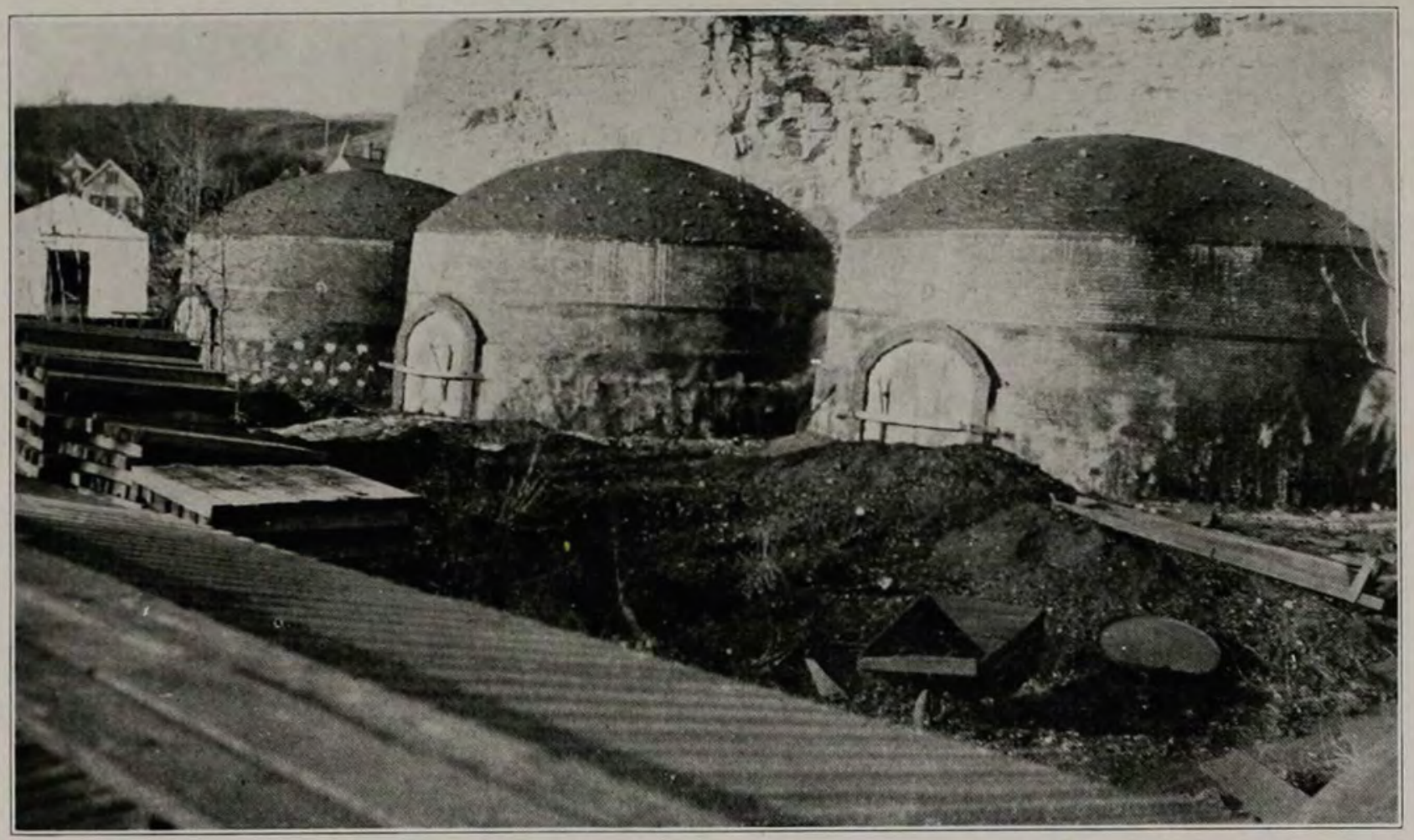

A battery of three charcoal kilns. These are built of brick, and charcoal is the only product secured. 
Plate XCViI

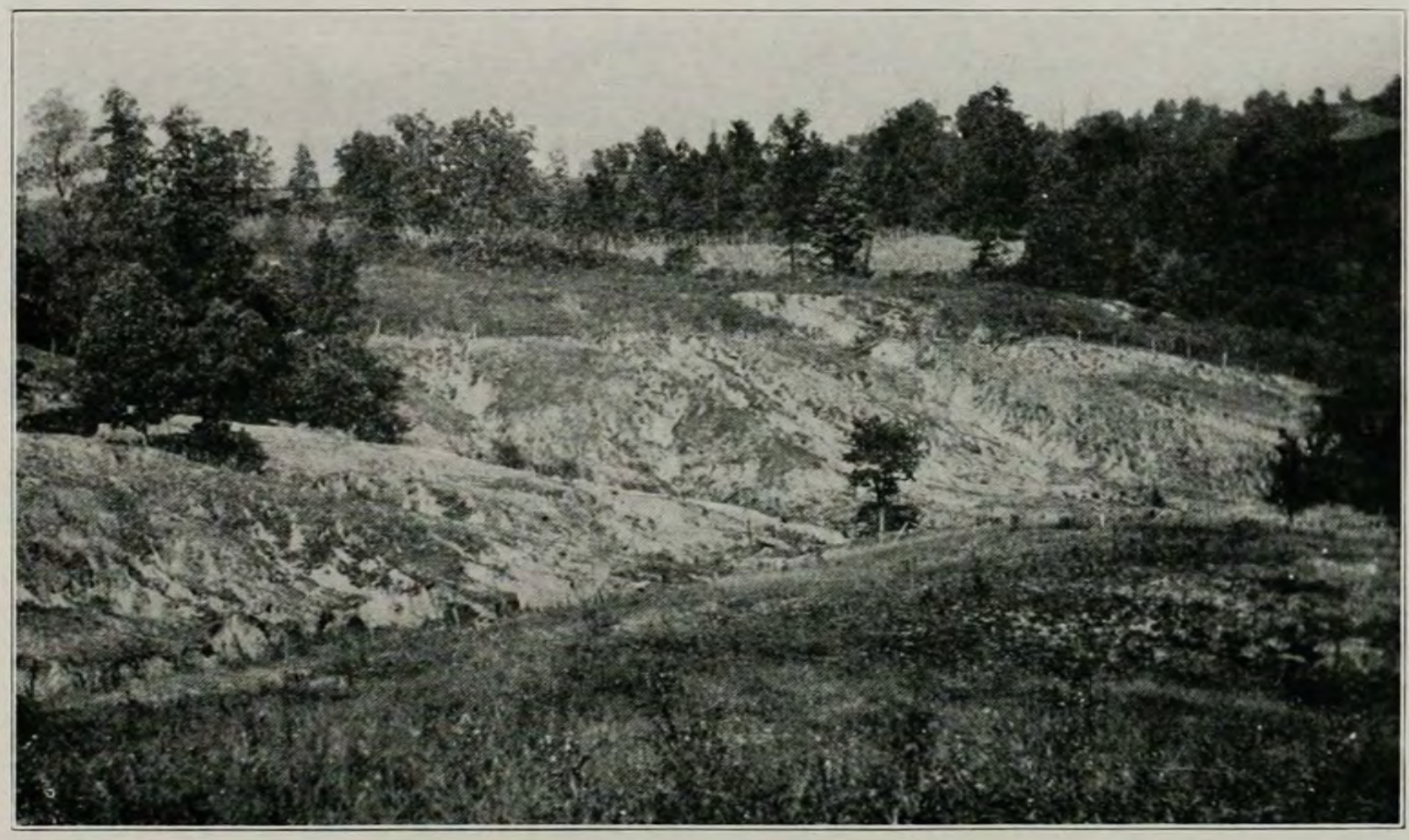

Erosion on a "forty" in Pomona township, Jackson county. 
Plate XCVIII

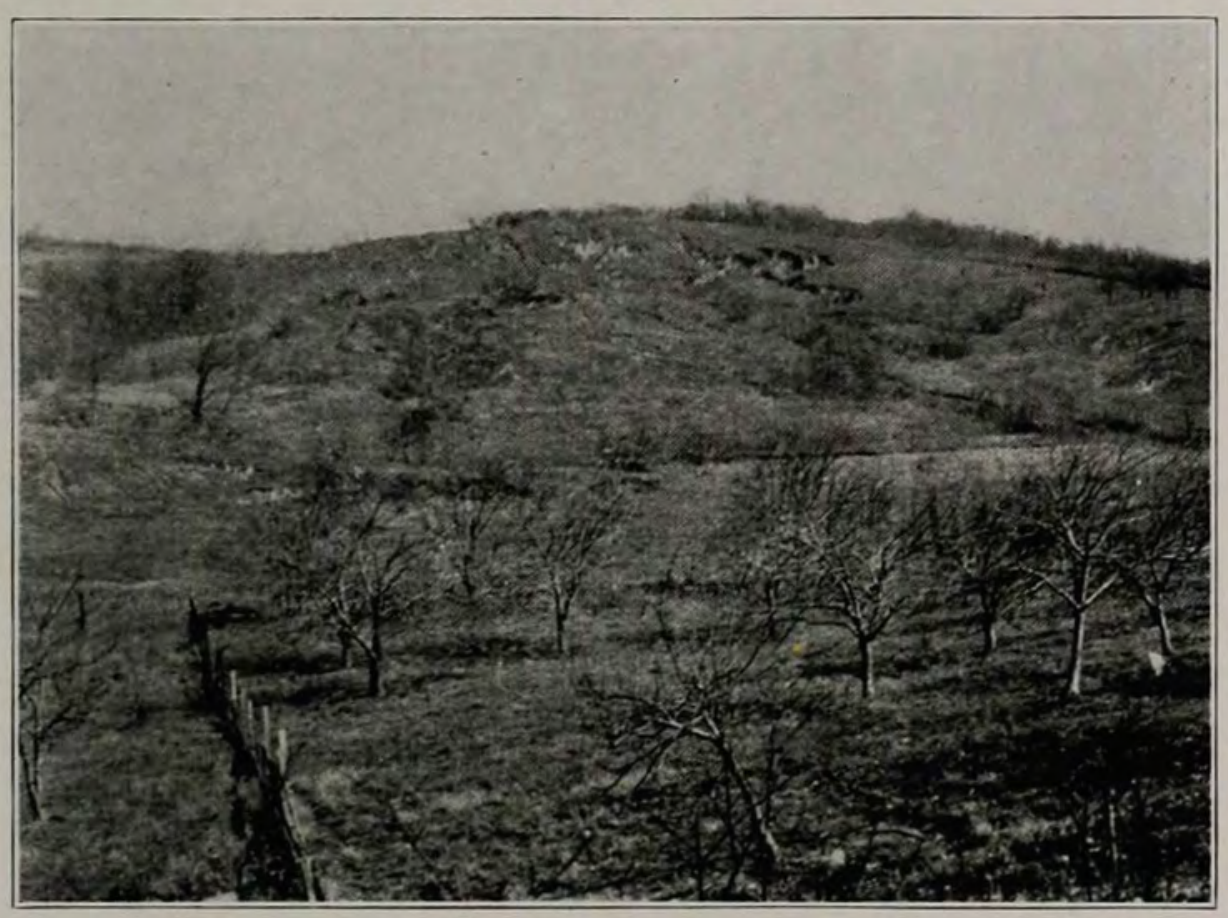

Erosion near Alto Pass, Union county. Photo by Paul J. Sedgwick. 
Plate XCIX

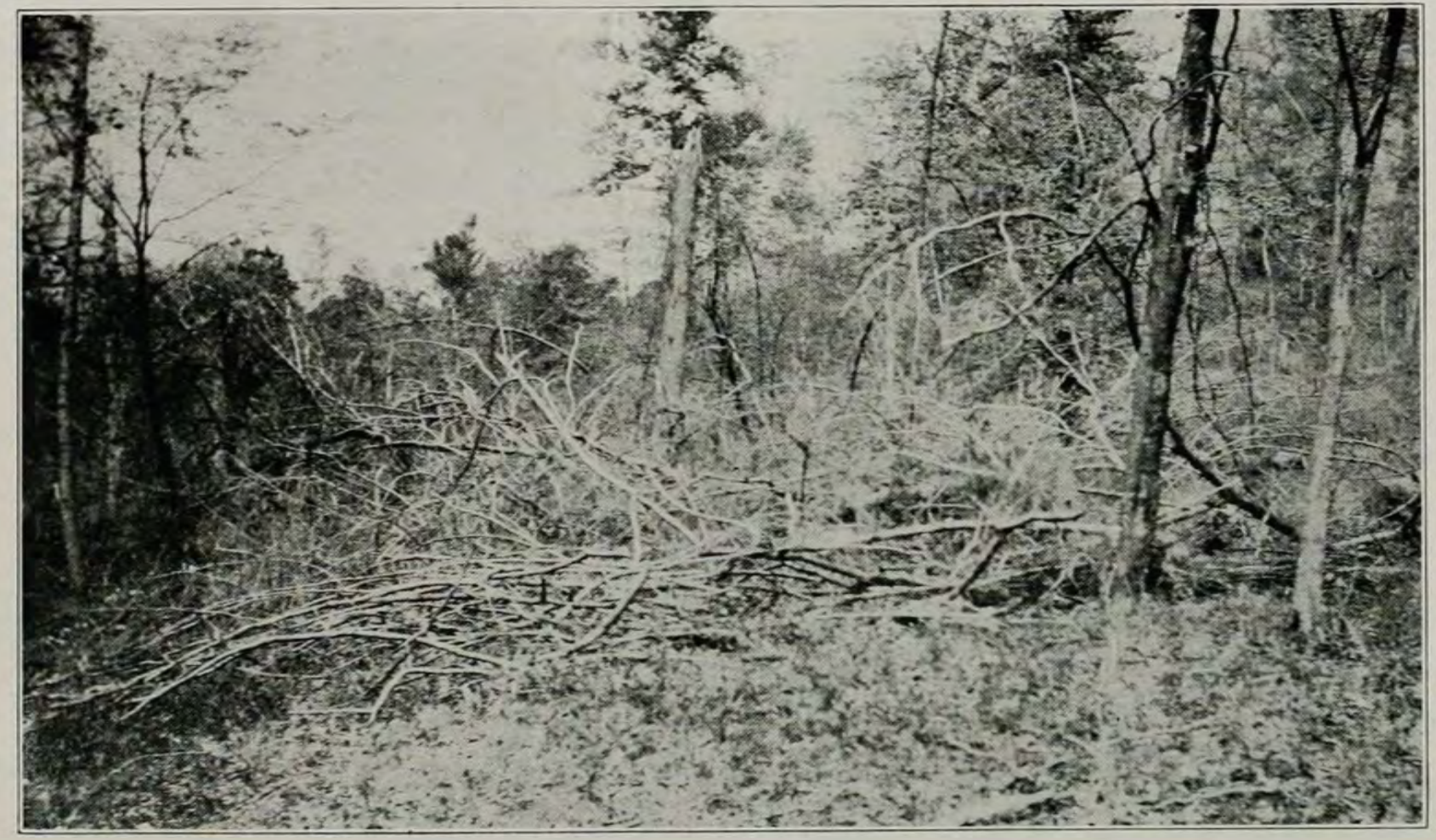

Lcgging slash left after a logging-and-tie operation. This is typical of the appearance of most cut-over lands. 
Plate C

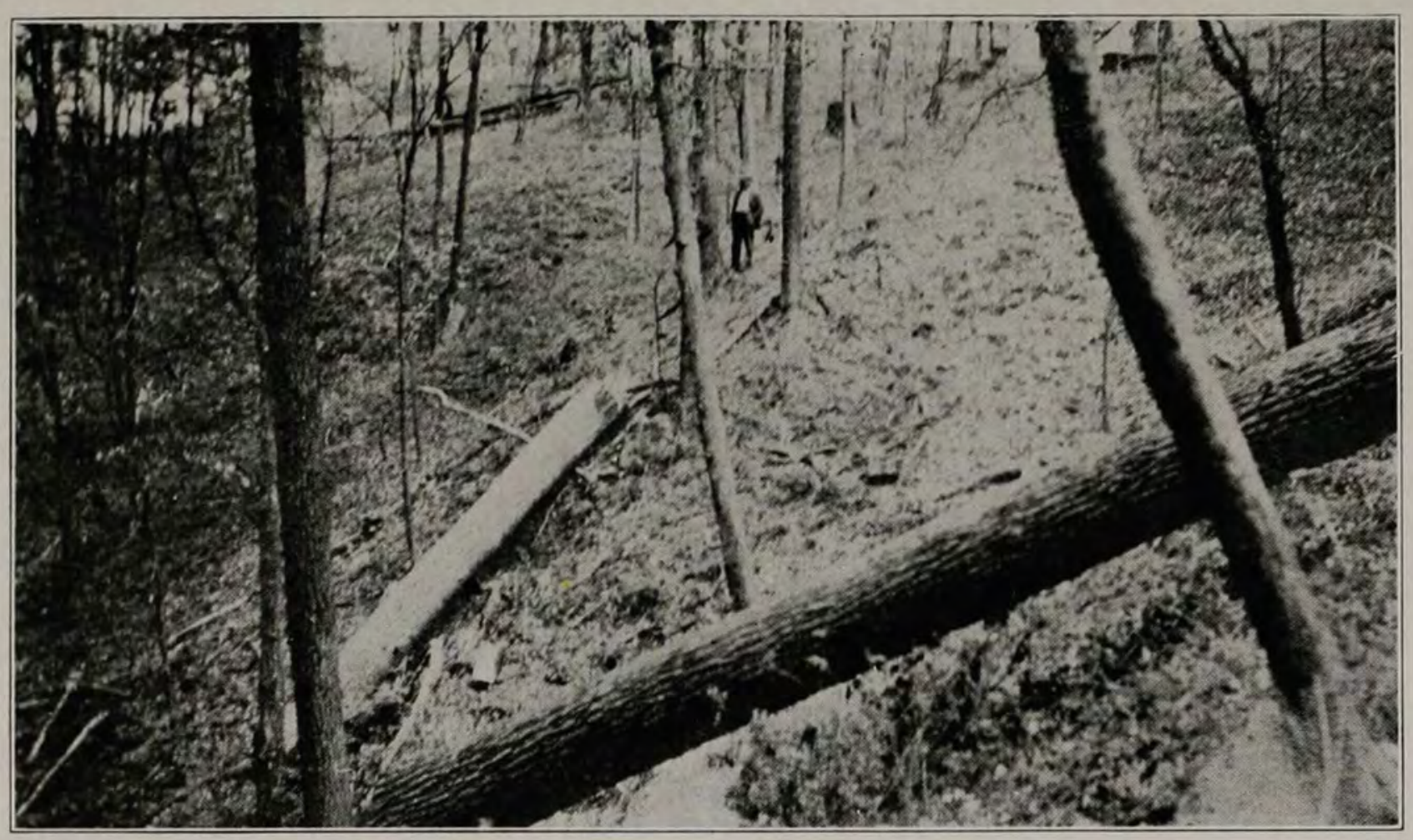

A burned-over side-slope at Alto Pass, Union county, on cherty soil. Notice the bare appearance of the ground and the fallen tulip-trees, indicating the severity of the fire. 


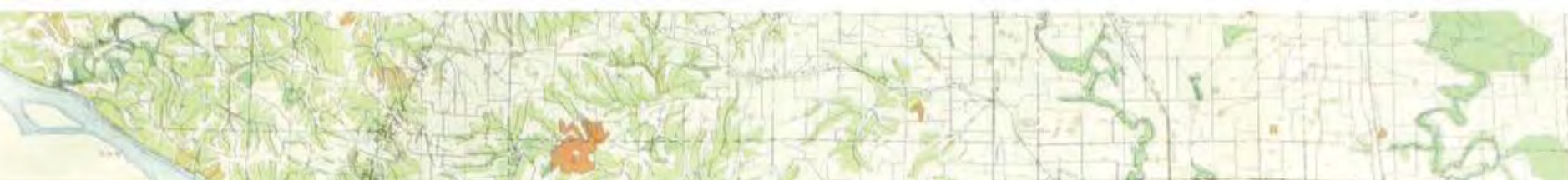

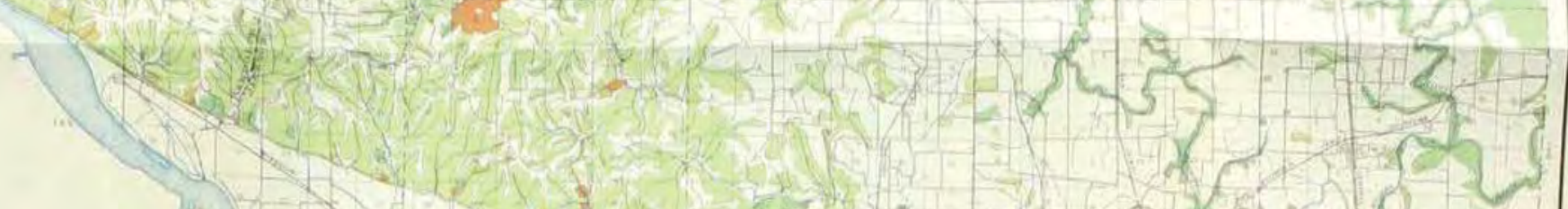

MAP OF

TIMBERED AREAS

exresmat riog

THEBES TO CHESTER, ILLINOIS

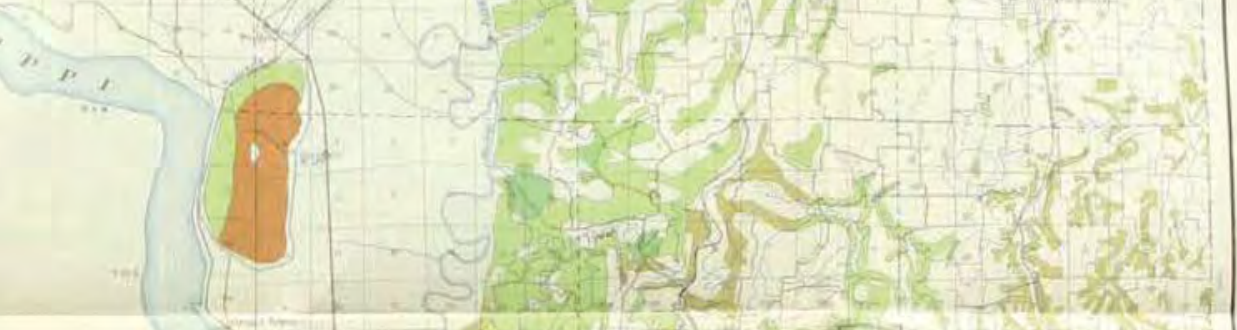

LEOEND
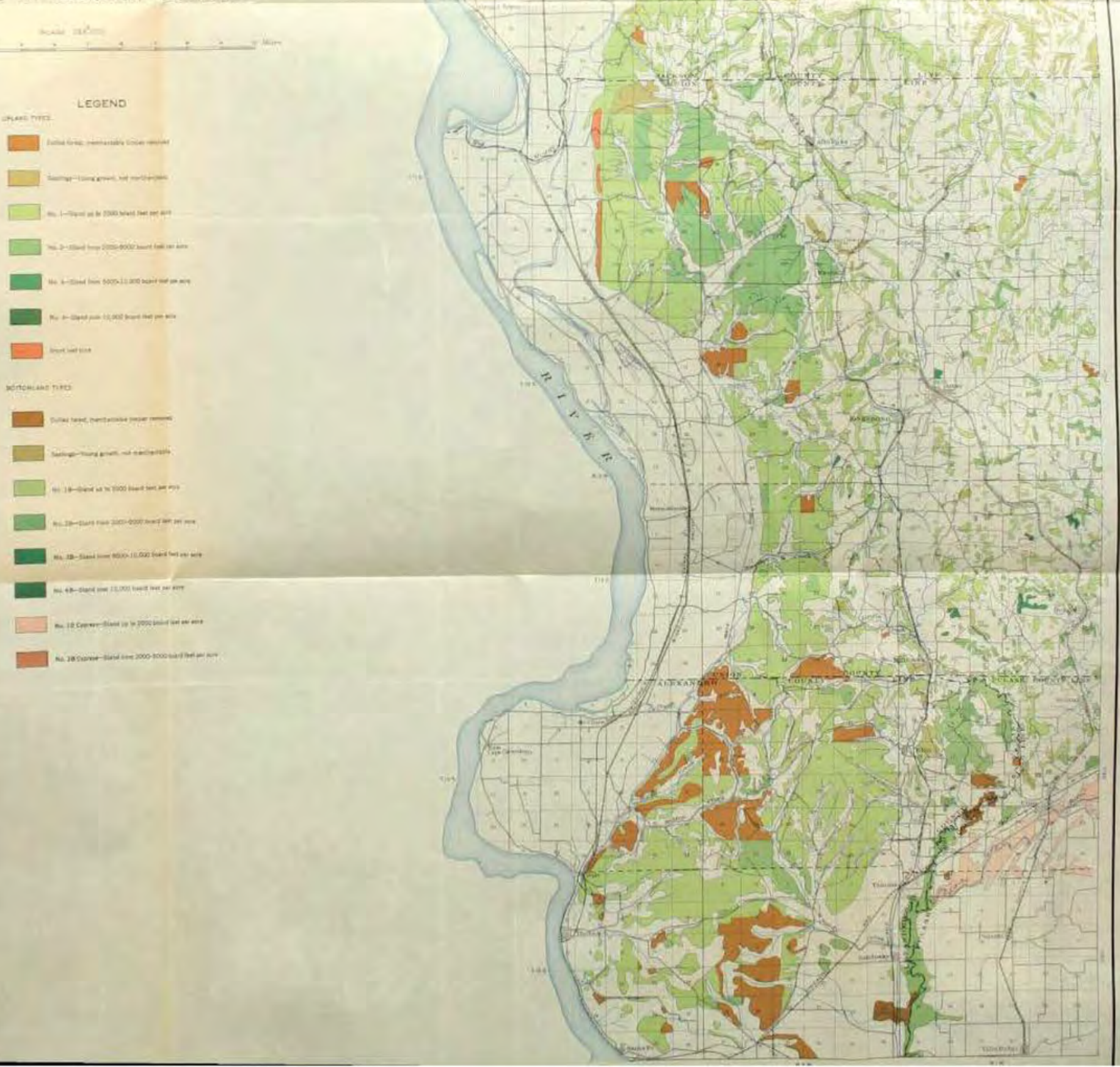
स6. 